\title{
Separations Innovative Concepts: Project Summary
}

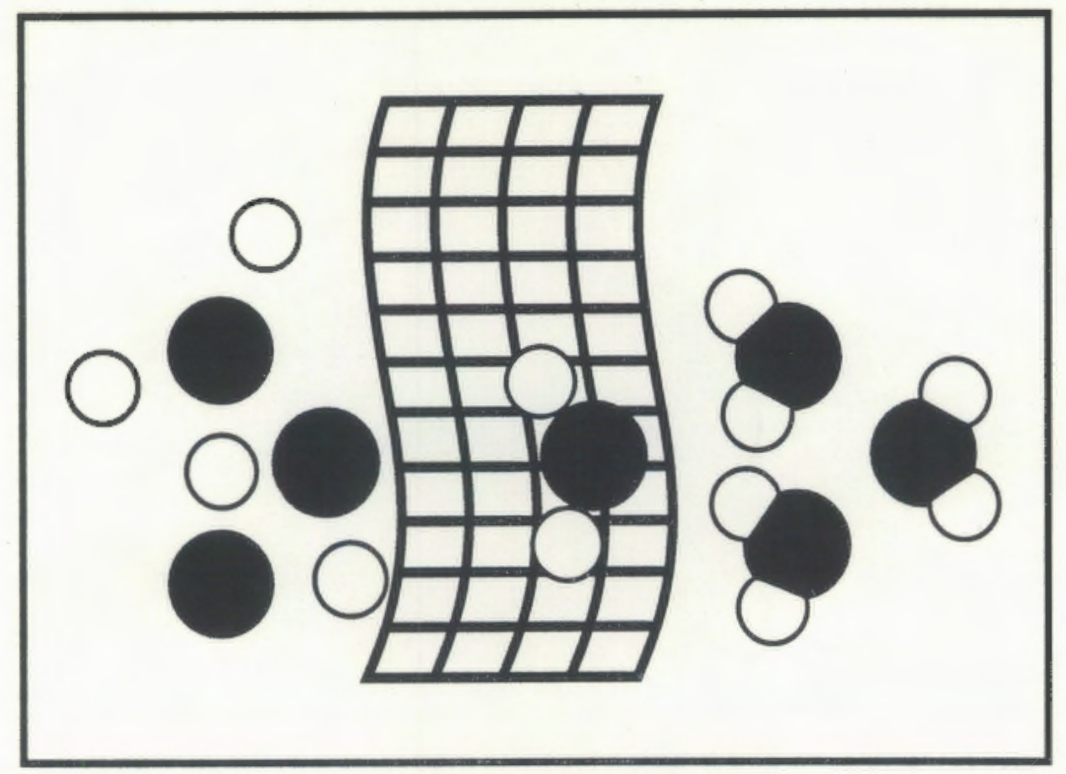

May 1988

Prepared for the U.S. Department of Energy under Contract DE-AC06-76RLO 1830

Pacific Northwest Laboratory

Operated for the U.S. Department of Energy by Battelle Memorial Institute 


\title{
DISCLAIMER
}

This report was prepared as an account of work sponsored by an agency of the United States Government. Neither the United States Government nor any agency thereof, nor Battelle Memorial Institute, nor any or their employees, makes any warranty, expressed or implied, or assumes any legal liability or responsibility for the accuracy, completeness, or usefulness of any information, apparatus, product, or process disclosed, or represents that its use would not infringe privately owned rights. Reference herein to any specific commercial product, process, or service by trade name, trademark, manufacturer, or otherwise does not necessarily constitute or imply its endorsement, recommendation, or favoring by the United States Government or any agency thereof, or Battelle Memorial Institute. The views and opinions of authors expressed herein do not necessarily state or reflect those of the United States Covernment or any agency thereof, or Battelle Memorial Institute.

\author{
PACIFIC NORTHWEST LABORATORY \\ operated by \\ BATTELLE MEMORIAL INSTITUTE \\ for the \\ UNITED STATES DEPARTMENT OF ENERGY \\ under Contract DE-AC06-76RLO 1830
}

\begin{tabular}{|c|c|}
\hline \multicolumn{2}{|c|}{ Printed in the United States of America } \\
\hline \multicolumn{2}{|c|}{$\begin{array}{c}\text { Available from } \\
\text { Nation }\end{array}$} \\
\hline \multicolumn{2}{|c|}{$\begin{array}{l}\text { National Technical Information Service } \\
\text { United States Department of Commerce }\end{array}$} \\
\hline \multicolumn{2}{|c|}{ S285 Port Royal Road } \\
\hline \multicolumn{2}{|c|}{ Springfiełd, Virginia 22161} \\
\hline \multirow{2}{*}{\multicolumn{2}{|c|}{$\begin{array}{l}\text { NTIS Price Codes } \\
\text { Microfiche A01 }\end{array}$}} \\
\hline & \\
\hline \multicolumn{2}{|c|}{ Printed Copy } \\
\hline & Price \\
\hline Pages & Codes \\
\hline $001-025$ & $\mathrm{~A} 02$ \\
\hline $026-050$ & $\mathrm{~A} 03$ \\
\hline $051-075$ & $\mathrm{~A} 04$ \\
\hline $076-100$ & A05 \\
\hline $101-125$ & $\mathrm{AOS}$ \\
\hline $126-150$ & A07 \\
\hline $151-175$ & $A 0 B$ \\
\hline $176-200$ & $\mathrm{A09}$ \\
\hline $201-225$ & $A 010$ \\
\hline $226-250$ & A011 \\
\hline $251-275$ & $\mathrm{~A} 012$ \\
\hline $276-300$ & A013 \\
\hline
\end{tabular}


SEPARATIONS INNOVATIVE CONCEPTS:

PROJECT SUMURY

R. L. Watts, Project Hanager

V. E. Loo, Editor

Way 1988

Prepared for the U.S. Department of Energy under Contract DE-AC66-76RLO 1B36 
$\bullet$

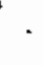

.

- 
This project sunary includes the results of 10 innovations that vere funded under the U.S. Departaent's Innovative Concept Programs. The concepts address innovations that can substantially reduce the energy used in industrial separations. Each paper describes the proposed concept, and discusses the concept's potential energy savings, market applications, technical feasibility, prior work and stato of the art, and future devolopeent needs. 


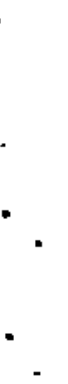


In 1982 the Office of Energy Systess Research within the U.S. Department of Energy (DOE) initiated the Innovative Concepts Progran. The objective of this progran is to identify immature concepts having the potential for saving substantial anounts of energy and to provide soed money for a prelininary investigation of their technical foasibility. This report provides information on the 10 innovative industrial concepts solocted for further exacination.

The approach used in this project assenes that a) good concepts cone frou oxperienced, knowlodgeable investigators, b) innovatora frequently generate core good ideas than can be used ithin their own organizations, and c) ideas are frequently generatod in an organization unable to realize the benofits of further development. Therefore, other industrial organizations or federal agencies may be interested in providing financial support for further development of such concepts.

This project is an experinent in a continuing progran to harvest ereative, novel approaches to saving energy. This year's fair oought innovative concepts and inventiona that could reduce onergy conatsation in industrial separations processes, specifically chesical processing, biotechnology soparations, wasto/fuel recovery, and process equipent. Approxinately 2.7 quad of onergy is consused by U.S. industry in separations processes. That consunption is many tines nore onergy than is required according to thermodymaic calculations.

Thirty-nine innovative proposals were received by the Innovative Concepts Progran in response to the formal call for concepts. The ten that wro solected to recoive soed coney and nonf inancial assistanco are sunarized belov.

\section{CHEIICN PRQCESSING}

Liguid-Liguid Separation in Svirling Flore Woing Friction-Reducing Polyners

The objective of this study was to oxplore the foasibility of separating snall amounts of oil dispersed in water by using swirling flows. The approach depends on two physical offects that have not been exploited previously: 1) the occurrence of a central toroidal recirculation zone for large swirl nubbers, and 2) the use of friction-roducing polyera to control the drop-aize distribution.

The nes separater design contains three distinct zones of separation. The resulting performance of the unique piggyback configuration is expected to give an equivalent tro-stage offect. Therofore, conpared vith uore conventional hydrocyclone designs for liquid-liquid separation, the proposed nev concept has the potential for 1) higher officiency per stage, 2) aore flexible turndom characteristics, and 3) lower power requirenente for an equivalent separztion perforeance. Although the nerits of the nes separator have not been tested, a prelieinary evaluation of the approach indicates that some of the above benefits are attainable.

\section{Efficient Recovery of Finely Divided Mineral Particles by Centrifugation}

An efficiant process to recovor heavy and finaly divided wineral particles frou light gangue ainerals has been investigated by imposing a delicate balance between centrifugal and surface tonsion forces on these particles. $A$ nixture of galena and silica fines of $400 / 500$ wesh size was used in this study as a nodel syston. Hydrophobic and heavy galena fines were soparated easily from hydrophilic and light silica particles in mater/organic liquid under centrifugal force. Better than 904 recovery vith B5X purity was possible in a two-liquid systen consisting of water and carbon tetrachloride with a centrifugal force less than ten times greater than the force produced by gravity. 


\section{BIDTECHMOLOGY SEPARATIONS}

\section{Biotechnology Separation of Pyrite fron Coal}

The uso of eircroorganisns, particularly lithotrophic bacteria such as Thiobacillus (T.) forrooxidans, was investigated as a cost-offective method for recovering cosl that is currently discarded as being too dirty to burn. The bacteria are used to aodify the surface of the pyrite particles contained in the sulfur. By altering the surface of the pyrite, it can be soparated froe the coal by the froth flotation process, a separation that would not be possible without pretresteent.

Experimente were conducted using two atrains of I ithotrophic bactoria, three species of nonlithotrophic bacteris, and one species of yeast. Results indicate that, tile all aircroorganians showed considerable ability to alter the pyrite surface and thus prevent flotation, the nost effective was one of the strains of $T$. ferrooxidans, which produced nearly complete suppression. The tests also deternined that the suppression is causec by direct collular attachnent and the action of intracellular onzyess, not by extracellular onzynes released into solution.

Periodic Crose-flon Separation of Large bolecules, Eapecially Proteins, According to their Diffusion Coeff icients

A nothod for soparnting relatively large nolecules that have different diffusion confficients has been developed. The nolecules, in solution in thoir natural solvent onvironment, are separated by two eutually porpendicular coordinated flows, both pariodic and bi-directional.

A athenatical nodel was developed and used to predict the performance of the nethod on a binary mixture of proteins in aqueous solution. The protoins are asuned to have nolecular diffusion coofficiento of $\mathbf{0 . 9} \times 10^{-7}$ and $1.0 \times 10^{-7} \mathrm{~cm}^{2} / \mathrm{s}$. Separation is calculated to occur in 1 hour with recoveries and purities oxcoeding $99 x$. Calculations indicate that higher recoveries and puritien any be readily achieved with somentat more processing tice; for exanple, 99.8I recovery and purity could require 2 hours of processing tine. The feed protein concentration is approxieately .4X . and the rate of processing is about 1 gral of protein per liter of separator channel voluae per hour.

Recovery of Dilute Aqueous Butanol by Adsorption on Lignin

This concept addreases a novel technique for concentrating dilute aqueous butanol and acetone using lignin derived froe oulfuric acid hydrolysie of bicases. Prolininary research has shom that lignin has the potential to selectively adsorb butanol, acetone, and perhaps othanol frot formentation broth containing augar and aslts. After adsorption, the $\mathrm{l}$ ignin can be regenerated by passing $\mathrm{CO}_{2}$ gas at $96 \mathrm{C}$. The lignin was ahom to rotain its adsorption capacity after regeneration with $\mathrm{CO}_{2}$.

\section{INSTE/FUE RECOVER}

Potential for Broader Applications of Extracting Hydrocarbons Using Liquid-Coro Polyaphrons

A proposed concept is being developed to extract the bitunon from tar sands at lov temperatures using liquid butane made up into a meter-continuous polyaphron sa the extractant. The preliainary evaluation of the proposed concept indicated that 1) tar sands represent a significant energy reserve; 2) hot vater extraction as practiced in Alberts is onergy intensive and unique in that many tar sands require different treateent; 3) aphrons eade of kerosene or butane can of fectively rewove bitwen frow tar sands that are not suited to hot water treateent; and 4) liquid butane in polyaphron for as the extracting solvent has potential for sieple cold separation and can be recyeled.

Fuel froe Mnicipal Sludge

A proposed process is being assessed for soparating a significant fraction of organic aterial froe municipal sludge by acid extraction and for reconstituting the extracted organic uatorial as a solid fuol. Experinental 
results have deeonatrated that $86 x$ of the solids can bo dissolved during acid extraction, and up to 25x of the initial solids can be precipitated shen diluted with wator. The precipitated product ras a high organic (gex to 985) solid and represented up to $39 x$ of the initial organics.

Prelieinary econonic estintes shor this process to be conpetitive with other gludge disposal and reuse alternative for wastevater treatnent plants serving one million people or are. The oconomic picture can be greatly inproved by incorporating the negative cost of sludge disposal.

\section{PROCESS ERUIPNEST}

Developent of an Electrostatic Agglonerater

The objective of this work ms to analytically inveatigate an electrostatic agglonerator that is designed to contral the fine particles in industrial processes and posar plant flue gases. The rosulto of the proliainary investigation of this concept indieate that the concept is fassible: particlea can be chargod and agglomerated, and the interparticle adhesion forces are strong enough to overcone collisional forces acting to break the agglonerates. The agglonerator can reduce both the energy consuaption and the capital equipaent costs of existing gas cleaning devices, and can reduce a respiratory health problen by increasing the officiency of collecting subuicron particles in oxisting filtration derices.

Large-Scale Generation of Nicrobubbles to Improve Flotation Processes and to Save Energy

A spinning cylindor currentiy is being tasted as an altormative eothod for econocically producing largo quantitios of high-quality colloidal gas aphrons. Prolininary rosults of bench-scale tests on the spinning cylinder indicato a considerable improvenent in gonersting wicrobubble with good stability and bubblo size, wininun roid air, and reasonable operating cost. A larger unit has been designed and is boing built for testing in this project.

Applications of Magnetic Cyclone

This concept addresses two potential applications of a agnetic cyclone. The first application exanines and demonstrates inproved recovery of fine magnetite. The fine magnetite used in conventional dense nedia plants for cos I cleaning is not fully recovered and recycled. The project results show that the angnetic cyclone can recover dense aedia nagnetite (as purchased by operators of dense media coal cleaning plants) offectively rithout excessive uagnetic fields or foed pressures. However, then sanples froe procese streans of coal cleaning plants were usad, the recoveries wre lower than vith pure agnetite, largoly because of the very fine aize of the magnetic particles in the process streans. Additional tests vill oxanine cyclone geosetry and agnetic field variations to further ieprove the agnetic cyclone recovery of these fine particles.

The second application concerna the deratering of steel plant sludges to allow these iron-bearing aterials to be disposed of or roused. To date a literature search has been undertaken to determine the characteristics and potential of this application. However, because appropriate plant samples were not available in tive to complete test work. That work should be cosplated by the ond of April 1988, when a conplote report will be made arailable. 
$+$ 


\section{ACKNOVLEDGUENTS}

The Separations Innovative Concepts Fair is the result of the efforts of several individuals and organizations. Funding for this project was provided by the U.S. Departaent of Energy's (DOE's) Dffice of Enorgy Utilization Research under the direction of John J. Brogan. Torry Levinson in the Eneray Convorsion Utilization Progran was the Progran Manager at DDE. Te gratefully acknosledge the cooperation of DOE's Office of Industrial Prograns.

Sone of the recent improvemants in the Innovative Concepts Prograe are due to the opportunities presented by the close adninistrative relationship with the Energy-Rolated Inventions Progran, lod by A. Jack Vitullo at the DOE and by Coorge Lenett at the National Bureau of Standards.

Several staff nembers at PML were involved in structuring the overall research effort, for witing and evaluating the procurenent documents, screening the proposals, making arrangenents for the Fair, and preparing materials for the Fair: Mark Anderson, Carol Bruneau, Robin Ekert, Bobi Garrett, Joe Hauth (patent attorney), Ron Smith, Steve Saith, and Sue Vickerman. 
$\downarrow$ - 
1.0 LIQUID-LIQUID SEPARATION IN SHIRING FLOUS USING FRICTION-REDUCING POLYUES. $\ldots \ldots \ldots \ldots \ldots \ldots \ldots \ldots$

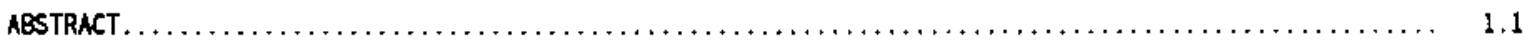

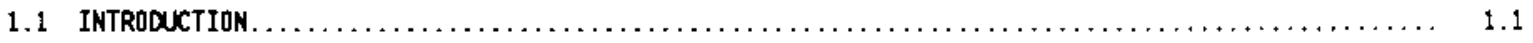

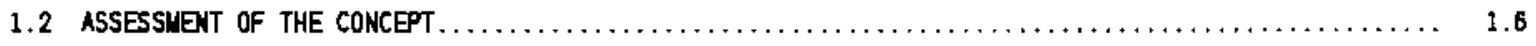

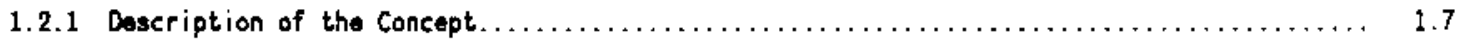

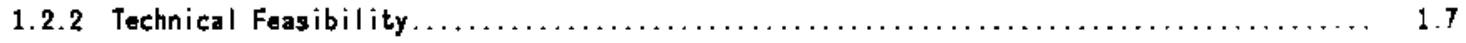

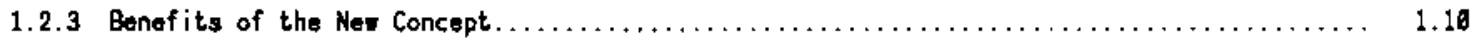

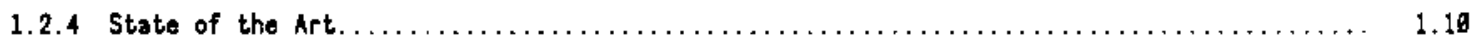

1.3 FUTURE CONCET DEVE

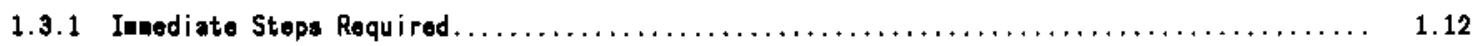

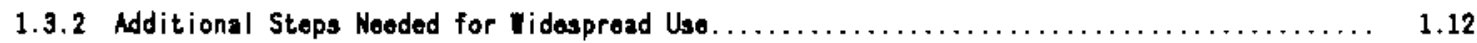

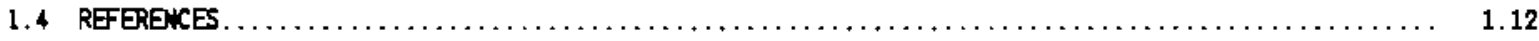

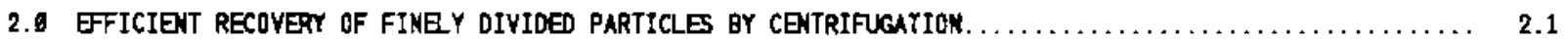

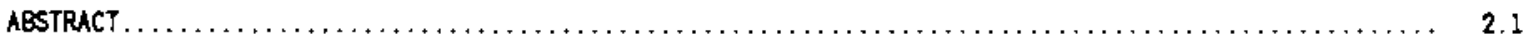

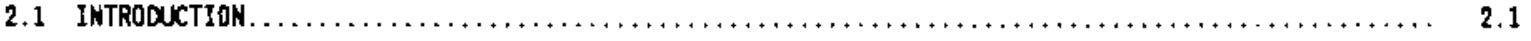

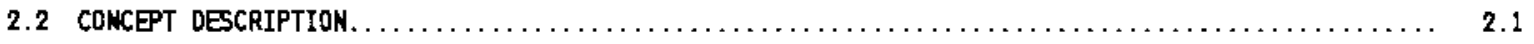

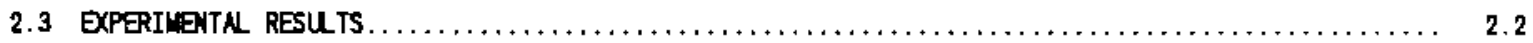

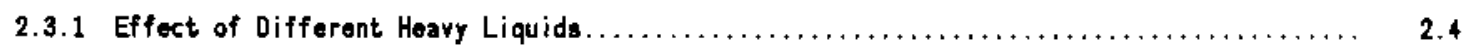

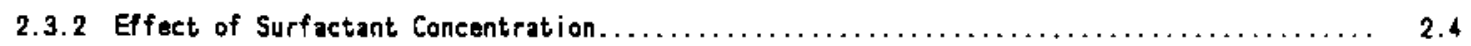

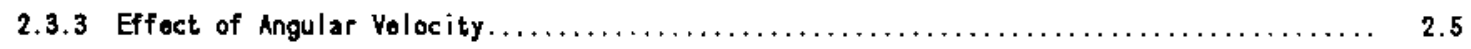

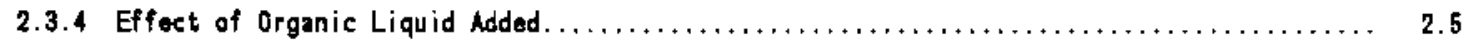

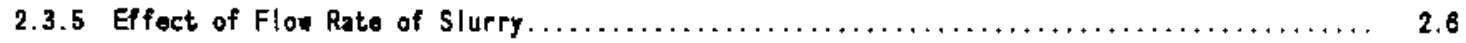

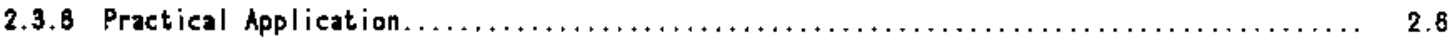

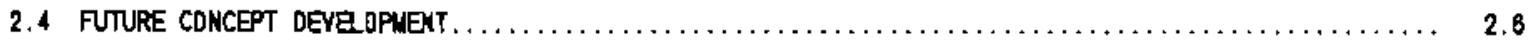

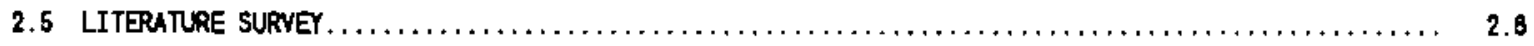

2.8 REFERE

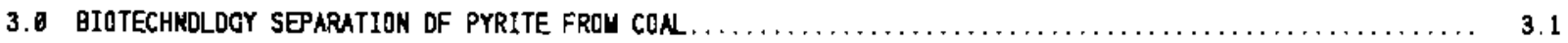

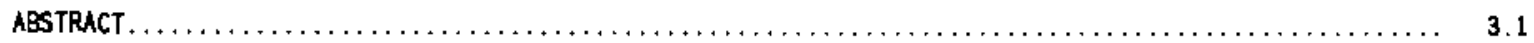

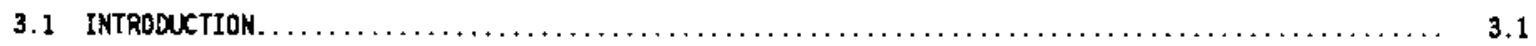

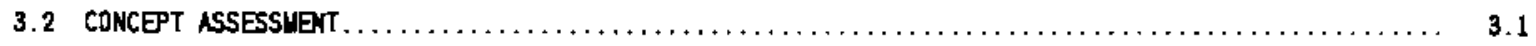

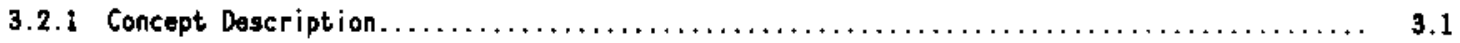

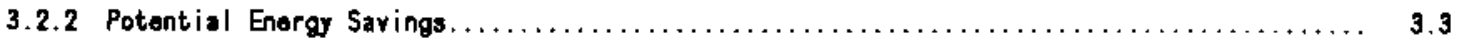

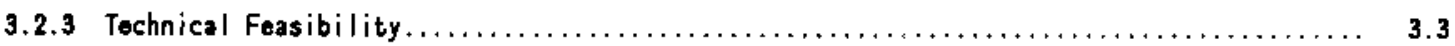

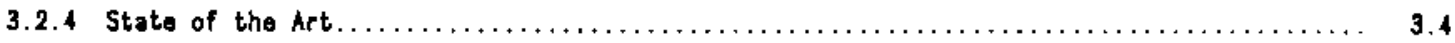




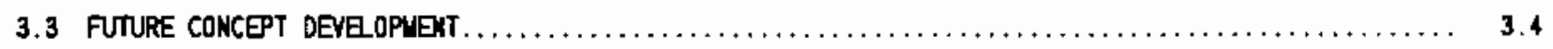

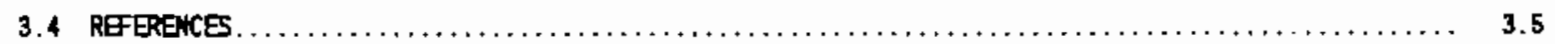

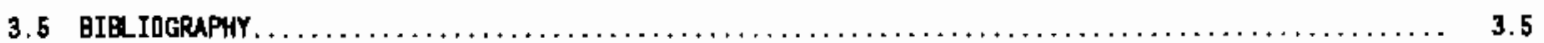

4.6 PERIODIC, CROSS-FLON SEPARATION OF LARGE MOLECUES, ESPECINШY PROTEIAS,

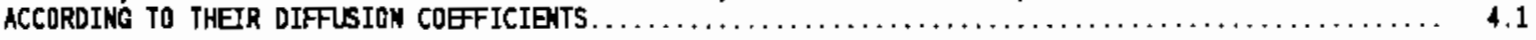

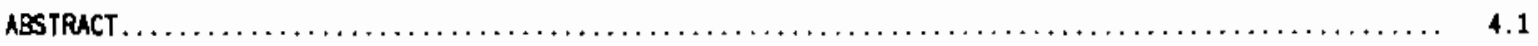

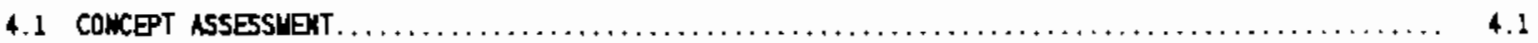

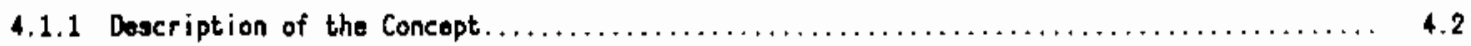

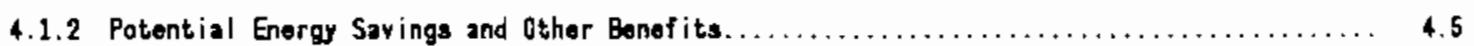

4.1.3 Technical Feasibility and Inpedinents to $\mathrm{Iide-Scale} \mathrm{Use \ldots \ldots \ldots \ldots \ldots \ldots \ldots \ldots \ldots \ldots \ldots} 4.6$

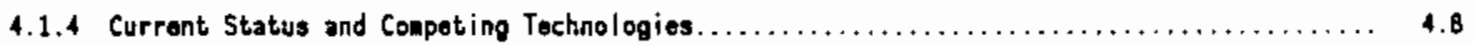

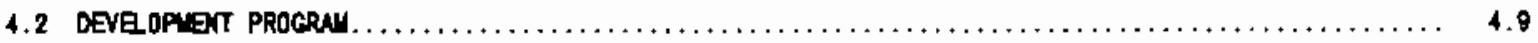

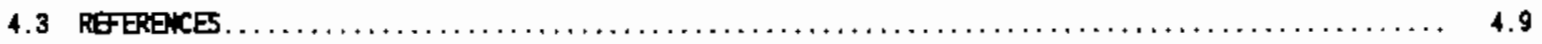

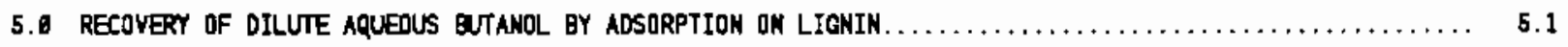

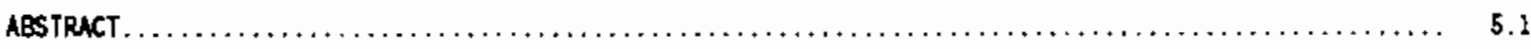

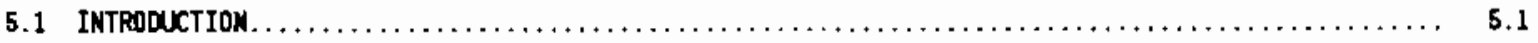

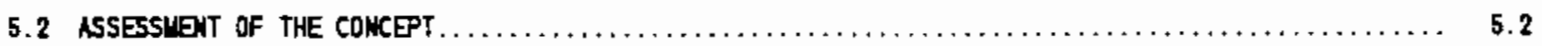

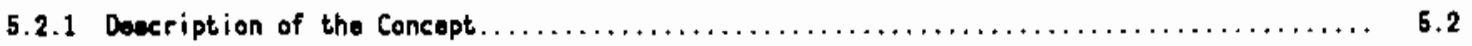

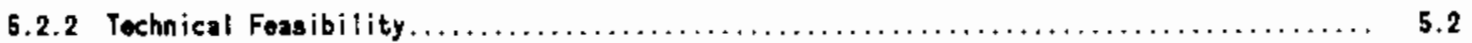

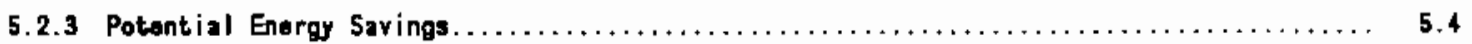

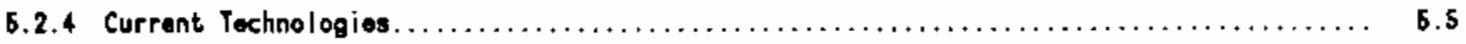

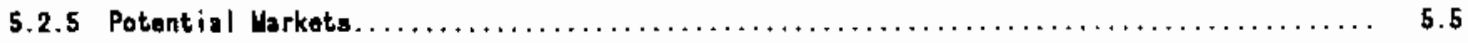

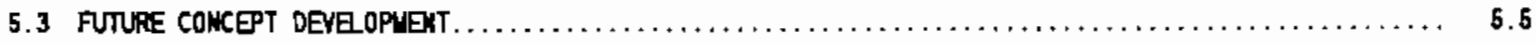

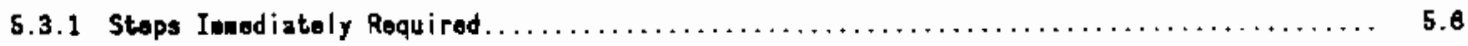

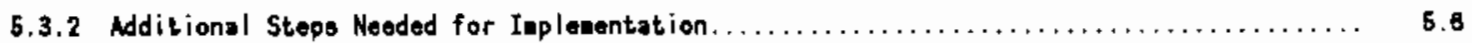

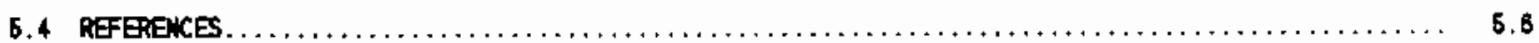

6. POTEATIAL FOR BROADER APPLICATIONS QF EXTRACTING HYDROCARBONS USING LIQUID-CORE POLYAPHRONS....... B.1

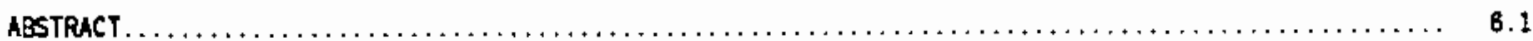

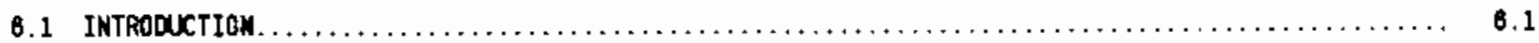

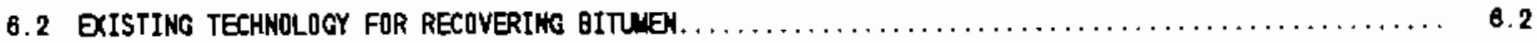

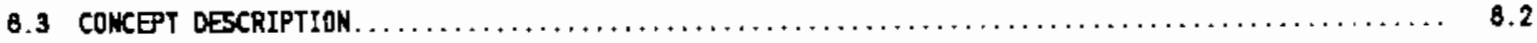

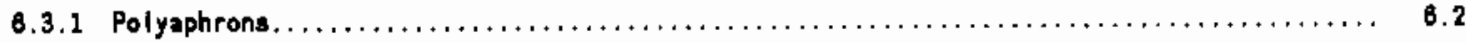

8.3.2 Effectiveness of a Kerosene Polyaphron Extraction.......................... 6.3

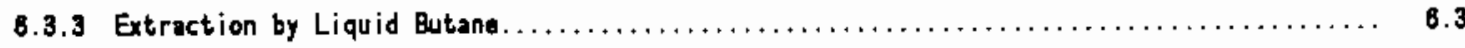

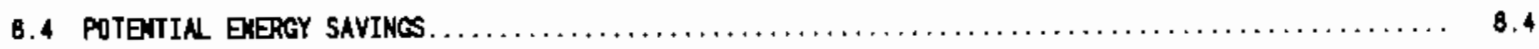




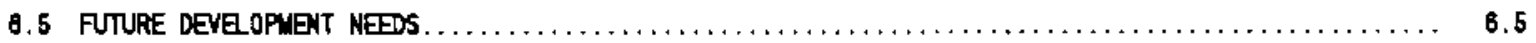

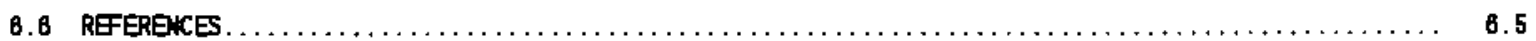

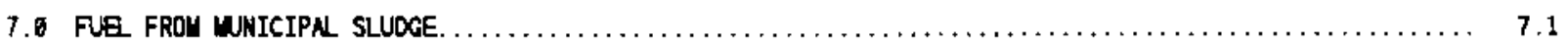

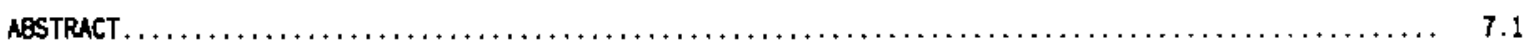

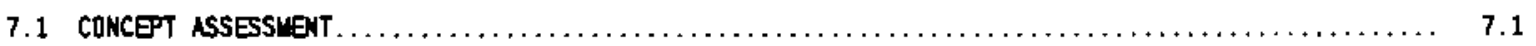

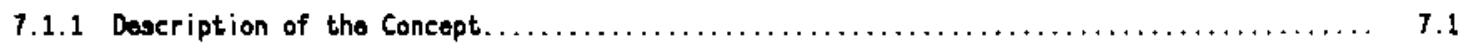

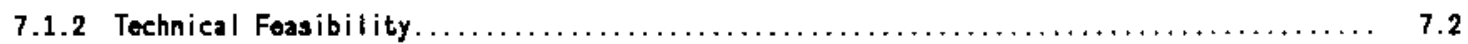

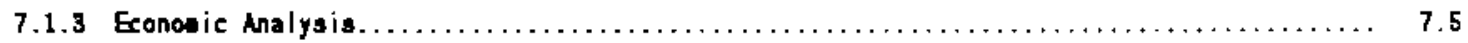

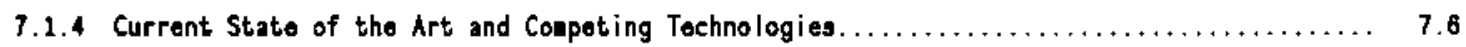

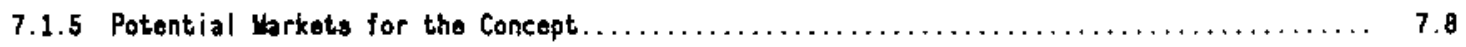

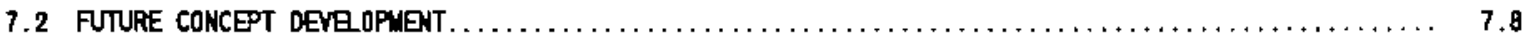

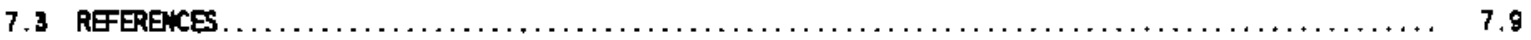

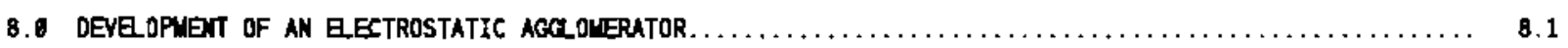

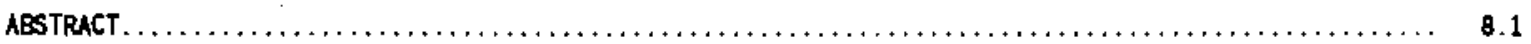

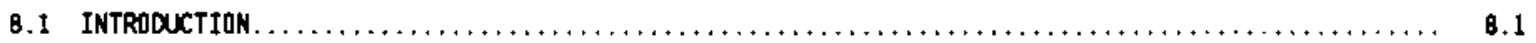

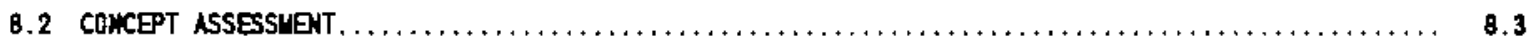

8.2.1 Description of the Electrostatic Agglonerator $\ldots \ldots \ldots \ldots \ldots \ldots \ldots \ldots \ldots \ldots \ldots \ldots \ldots$

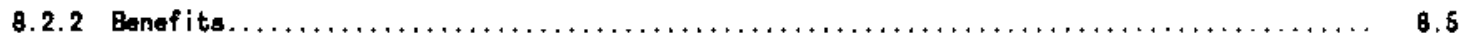

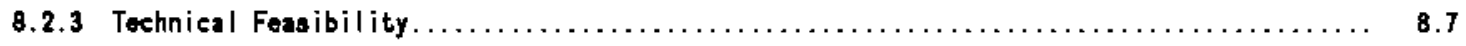

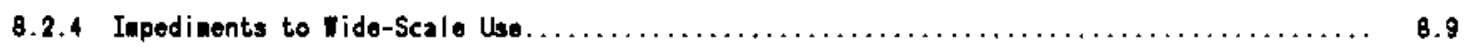

8.2.5 State of the Art of Conpeting Technologies $\ldots \ldots \ldots \ldots \ldots \ldots \ldots \ldots \ldots \ldots \ldots \ldots \ldots \ldots$

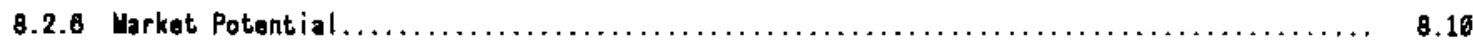

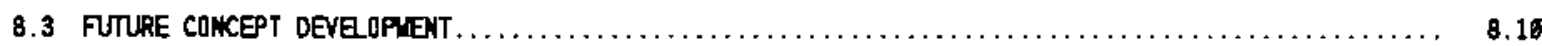

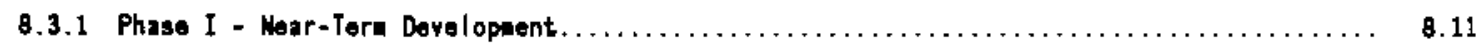

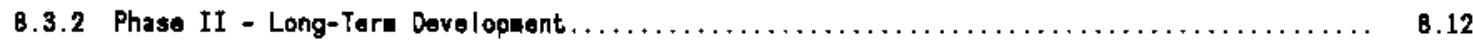

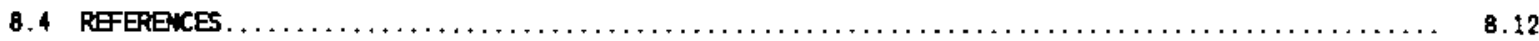

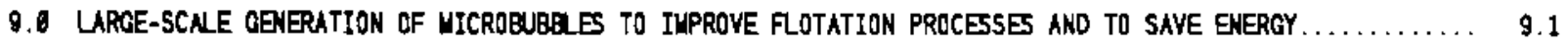

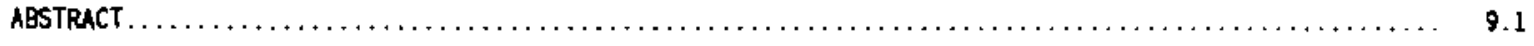

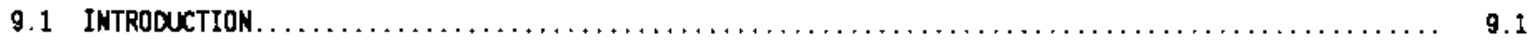

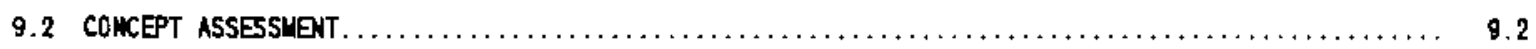

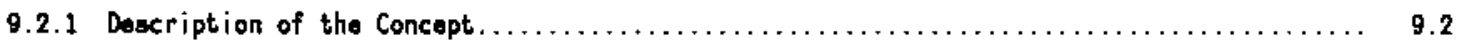

9.2.2 Potential Energy Savings $\ldots \ldots \ldots \ldots \ldots \ldots \ldots \ldots \ldots \ldots \ldots \ldots \ldots \ldots \ldots \ldots \ldots \ldots \ldots \ldots \ldots$

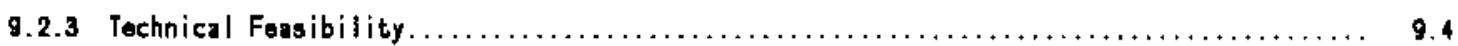

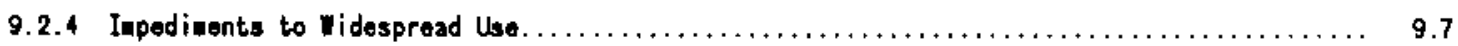

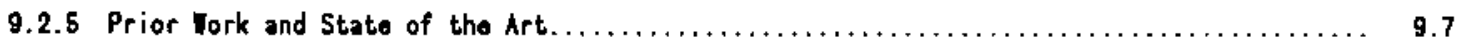




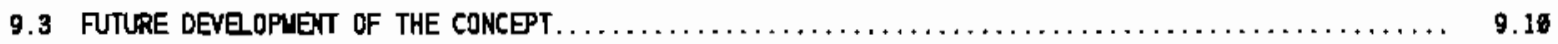

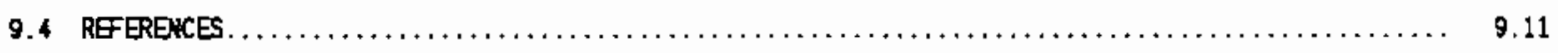

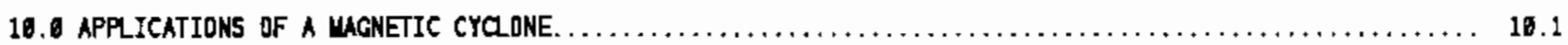

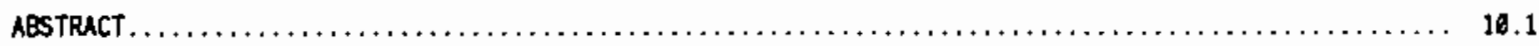

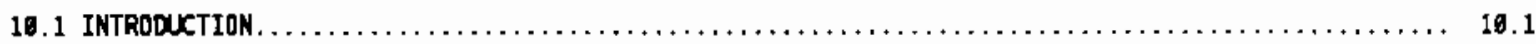

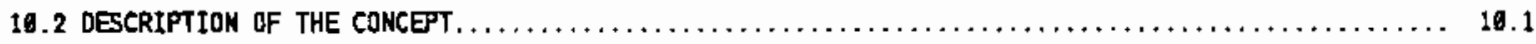

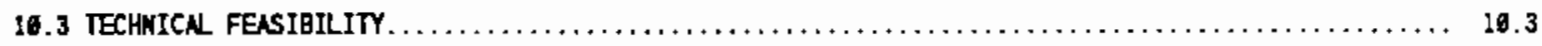

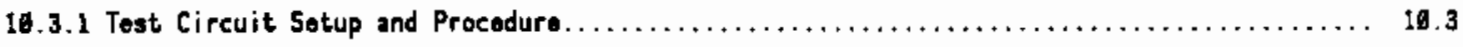

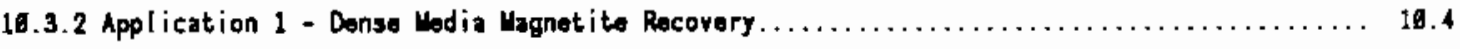

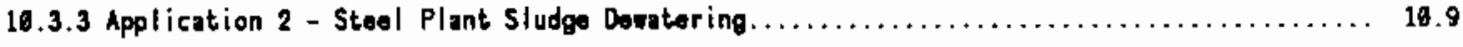

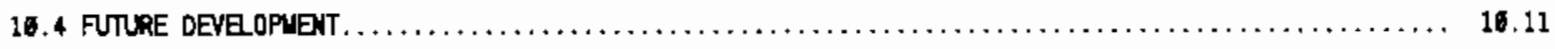

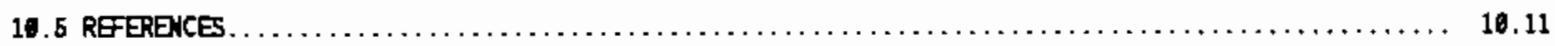

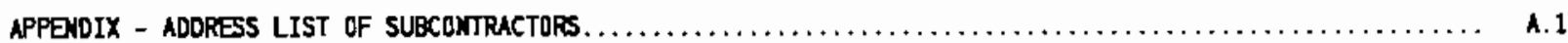




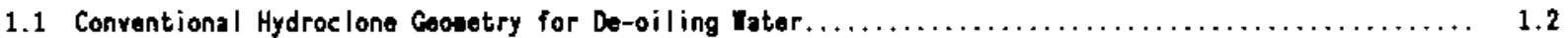

1.2 Critical Separation Size Based on Particlo Residence Tise Within a Free Vortex.................

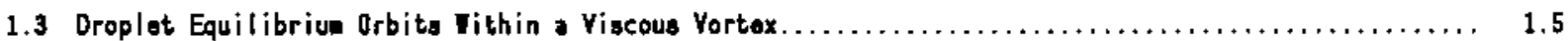

1.4 Central Toroidal Recirculation Zone (CTRZ) at High Stirl Nubers $\ldots \ldots \ldots \ldots \ldots \ldots \ldots \ldots \ldots \ldots \ldots \ldots$

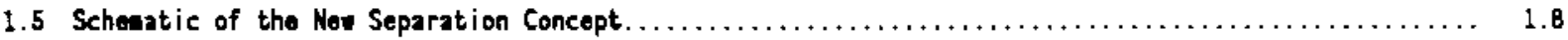

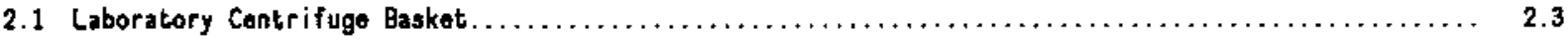

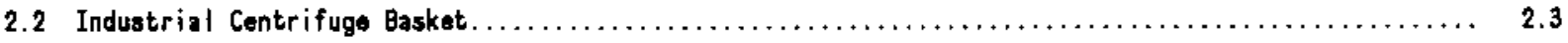

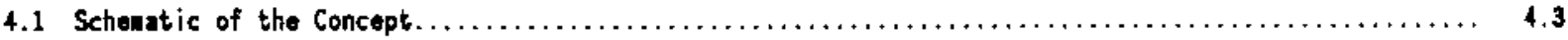

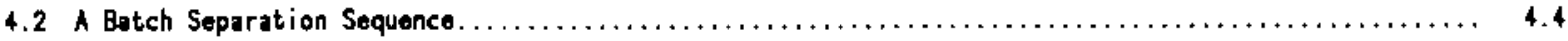

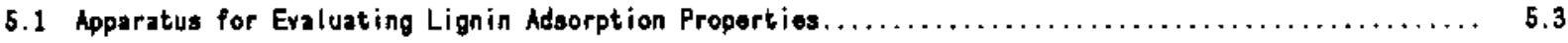

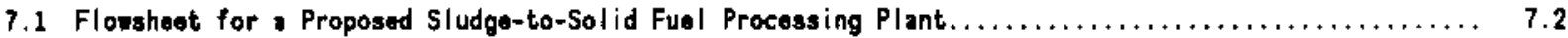

7.2 Dissolution of Total Solids for the Three Acid Strengths as a Function

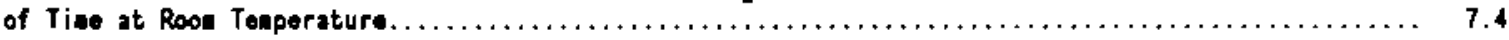

8.1 Size Distributions of Particles Eaitted fron Uncontrollod Porer Plants......................

B.2 Extrapolated Collection Efficiencies as a Function of Particle Sizo for Various Filtration Devices.. 8.3

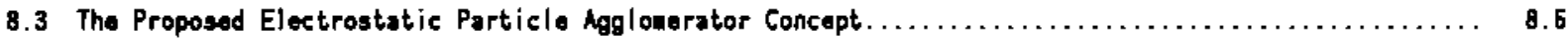

9.4 Schenatic of an Experinental Electrostatic Agglonerator Indicating Traversing

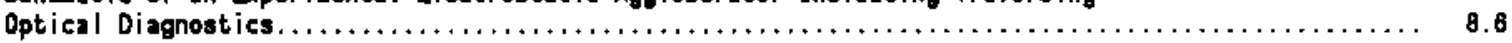

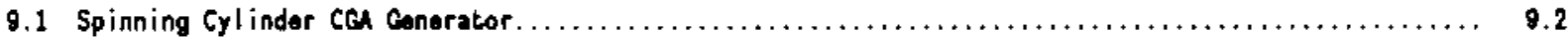

9.2 Stability as a Function of Liquid Flon Rate ("g configuration) $\ldots \ldots \ldots \ldots \ldots \ldots \ldots \ldots \ldots \ldots$

9.3 Stability as a Function of RPu or Spinning Dovice ('g' configuration) $\ldots \ldots \ldots \ldots \ldots \ldots \ldots \ldots \ldots$

9.4 Air Utilization (nicrobubbles foraed) as a Function of Liquid Flov Rate ('gr configuration)........ 9.7

9.5 Air Utilization (aicrobubblos forned) as a Function of Spinning Device ('B' configuration)........ 9.7

9.8 Air Utilization (wicrobubbles foraed) as a Function of Liquid Flos Rate ('E' configuration)........ 9.8

9.7 Air Utilization (nicrobubbles forned) as a Function of RPy of Spinning Device ('E' configuration) 9.8

9.8 Skability as a Function of Liquid Flon Rate ("E' configuration) $\ldots \ldots \ldots \ldots \ldots \ldots \ldots \ldots \ldots \ldots \ldots \ldots$

9.9 Stability as a Function of RPU of Spinning Devica ('E' configuration) $\ldots \ldots \ldots \ldots \ldots \ldots \ldots \ldots \ldots$. .9

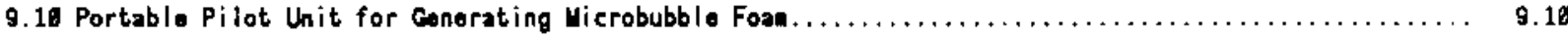

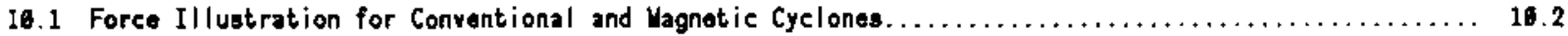

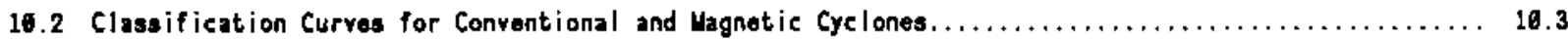

10.3 Laboratory Experinental Circuit. $\ldots \ldots \ldots \ldots \ldots \ldots \ldots \ldots \ldots \ldots \ldots \ldots \ldots \ldots \ldots \ldots \ldots \ldots \ldots \ldots \ldots \ldots, 10.4$

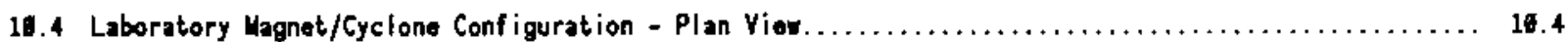

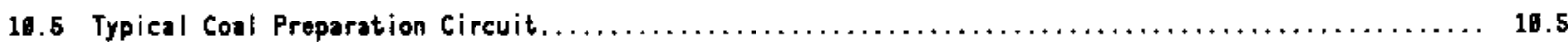

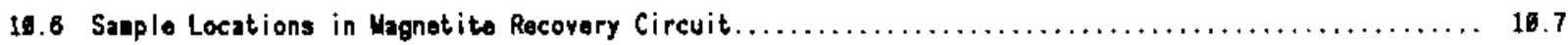

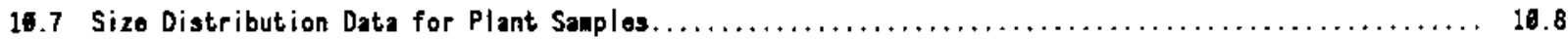




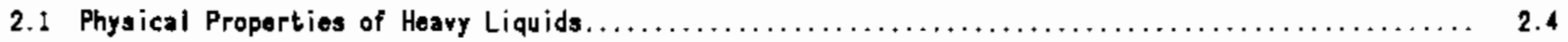

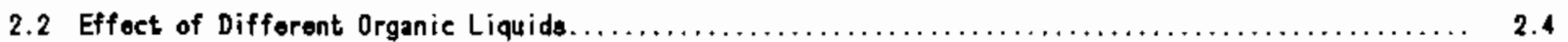

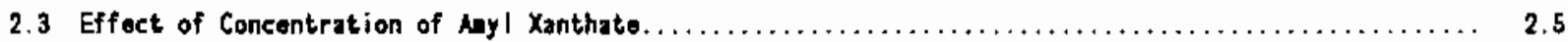

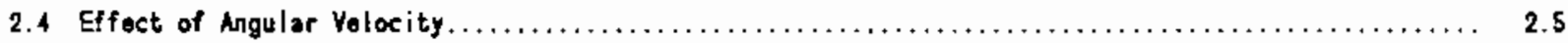

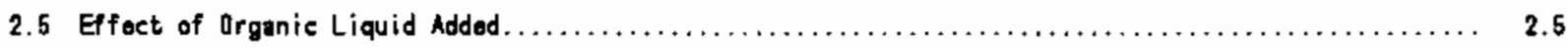

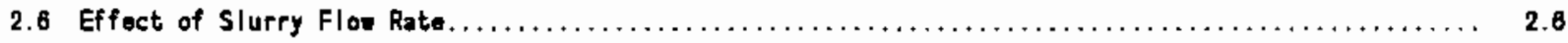

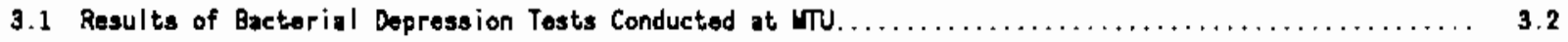

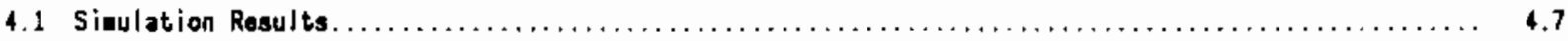

5.1 Apparatus for Evaluating Lignin Adsorption Properties $\ldots \ldots \ldots \ldots \ldots \ldots \ldots \ldots \ldots \ldots \ldots \ldots \ldots \ldots \ldots \ldots$

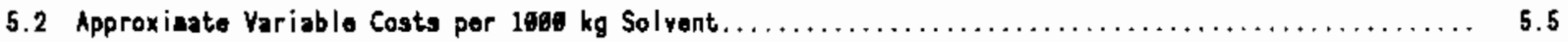

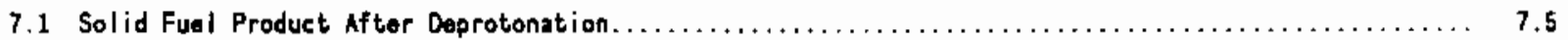

7.2 Production Costs ( $/$ /dry notric ton) for a Sludge-to-Solid Fuol Processing Plant as a

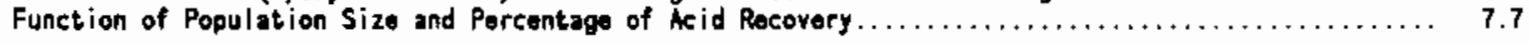

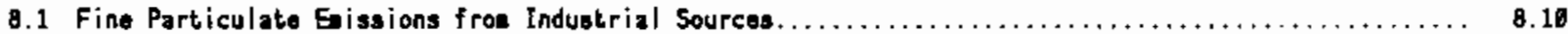

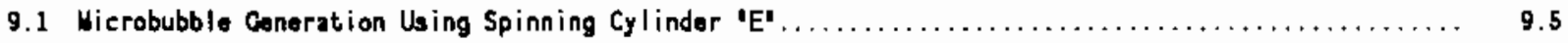

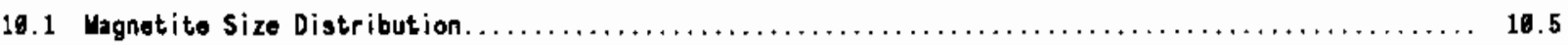

10.2 Circuit Variations and Pressure-Drop Effects on Wagnetite Recovery. $\ldots \ldots \ldots \ldots \ldots \ldots \ldots \ldots \ldots \ldots$

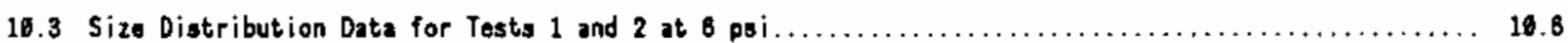

10.4 Effect of Increased Feed Solids' Content on Solids' Recovery in the One Vagnet

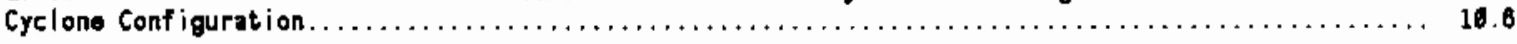

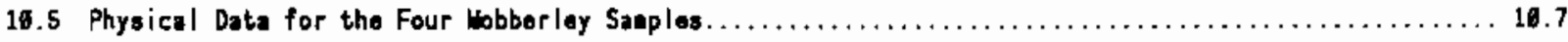

10.8 Cireuit Conf igurztion Effects on Solids' Recovery for Sample $\ldots \ldots \ldots \ldots \ldots \ldots \ldots \ldots$

10.7 Circuit Configuration Effects on Solids' Rocovery for Sanplo $8 \ldots \ldots \ldots \ldots \ldots \ldots \ldots \ldots \ldots \ldots$

10.8 Circuit Configuration Effocts on Solids' Recovery for Sample $\ldots \ldots \ldots \ldots \ldots \ldots \ldots \ldots \ldots \ldots \ldots \ldots$

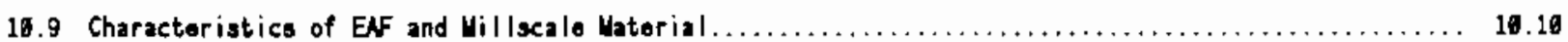




\section{INTRODUCTION}

The initiation of invention/innovation neods to be accolerated in the United States in order to speed up the entire process of technology transfer. During the past several years, business leaders, engineers, scientists, and lately, politicians have recognized that our industrial conpetitiveness has been deteriorating whilo our excellence in research continues. This trend has produced a groving consensus that we must ieprove our ability to bridge the gap between research and the uarketplace in the United States. To can no longer afford the patterns of the past where innovative technology trickled out into the marketplace in a serial process that took as auch as 25 years. International competitors are bringing tocinology into the warketplace in conths instead of years. Many solutions aro being proposed to accelerate technology into the marketplace. Acceleration of the latter stages of this process is already occurring.

The Departwent of Energy (DOE) established the Innoyative Concepts Progran (ICP) in the Dffice of Energy Utilization Research (EUR) in 1983 after two years of planning. The ICP objoctive is to develop and dewonstrato nethods for identifying and encouraging the growh of inature concepto having the potential to save energy and increase productivity through innovative approaches fundasentally different froe current practice. The ICP is encouraging the first steps of the invention/innovation (technology transfer) process.

Pacific Morthwest Laboratory $(P+L)^{(a)}$ operates this prograe for the oDE to identify long-range, high-payoff concepte to:

- provide a bridge betwen fundanental scientific progress and the technology areas of EUR

- identify large onergy-saving inprovenonts to ol ioinate energy-intensive activities.

The progran is designed to accouplish these tasks by the following activities:

- identifying a focus area (for example, industrial processes) for a cycle of innovation

- soliciting concepts in this focus area and solecting a linitod nuber for further investigation

- providing uodest funding to innovators for investigating the concepts' tochnical and business potential

- personally visiting oach inventor to provide oncouragenent and concrebs suggestions for anking the most officient use of the linited funding

- introducing the selected concepts to potential sponsors.

This document is provided to assist potential sponsors in their search for worthwile industrially oriented products or prograns.

Innovators who originated these concept. roceived approxieately s15K to perfora a prelicinary investigation of the tectinical and business potential of a concept. A prolininary investigation sometimes proves that a concept is not technically feasible. On the other hand, it say reveal sufficient information to shor that the concept should be developed further.

The original goal was to have 105 of the concepts accepted for funding by ICP to roceivo follos-on funding by other prograns or organizations. This is the third funding cycie sponsered by the ICP. Twelve buildings concepts and 10 industrial process concepts were funded and presented in two technology fairs, Buildings Innovative Concepts in May of 1984 and Industrial Innovative Concepts in Movember of 1985 . Six of those 22 concepts received

(a) Pacific Northwest Laboratory is operated for the U.S. Departent of Energy by Battel le Nenorial Institute. 
substantial follow-on funding from other sources. Two of the six resulted in the fornation of spin-off companies. Several additional concepts are being actively considered for follow-on funding.

In this funding cyele, ICP sought innovative concepts and inventions that could reduce energy consunption in induatrial processes: chenical processing, biotechnology separations, waste/fuel recovery, and process equipsent. 
CHEIICN PROCESSING 


\title{
1.0 LIQUID-LIQUID SEPARATION IN SWIRLING FLOWS USING FRICTION-REUUCING POLMERS
}

\author{
C.A. Potty, R.G. Drorak, and H.C. Chen \\ Department of Chenical Engineering \\ Uichigan State University
}

\section{ABSTRACT}

The objective of this study was to explore the feasibility of separating sall anounts of oil dispersed in water by using suirling flows. The approach depends on two physical offects that have not been exploited previously: 1) the occurrence of a central toroidal recirculation zone for large sairl nubbers, and 2) the use of friction-reducing polymers to control the drop-size distribution.

By introducing a dilute dispersion into a vortex field as an annular swirling jet, a toroidal recirculation zone forns about the axis of the vortex. This secondary flow provides a novel weans to capture oil droplets fron the a in flow field and to redirect then to an effluent orifice. Turbulent fluctuations on the axis of the vortex and within the central toroidal recirculation zone may cause the liquid drops to break into finer drops. However, by injecting a high molecular weight polyner into the core region of the vortex, turbulent fluctuations are dampened. If this stabilizes the internal drop-size distribution, then a more officient separation vill result.

The new separator design contains three distinct zones of separation. The resulting perforuance of the unique piggyback configuration is expected to give an equivalent two-stage of fect. Therefore, conpared with nore conventional hydrocyclone designs for liquid-liquid separation, the proposed new concept has the potential for 1) higher efficiency per stage, 2) wore flexible turndown characteriatics, and 3) lower power requirenents for an equivalent separation perforance. Although the merits of the new separator have not been tested, a prel ia $i-$ nary evaluation of the approach indicates that sone of the above benefits are attainable.

The potential iapact of the new proposal for de-oiling water on offshore platforas is significant because only two anufacturers currently offer a product for this application. A six-month study is needed to evaluate the technical performance of the new separation concept and to develop a prototype device for field study. The relative merits of the new approach vill be compared with the perforance of other hydrocyclone technologies currently being used.

\subsection{INTRODUCTION}

Hydrocarbon contanination of the oceans and estuaries is obviously undesirable, and eaission standards for discharging bilge water fron oil tankers and formation water from offshore platforas are challenging the available technology (Johnston and Halliwell 1976; Lucas 1975).

Currently, $38 \mathrm{ppa}$ by volume is the allowable daily average concentration of free oil in the discharge water frow platforms in the Bass Strait near Molbourne (Hayes, Carroll and Fothergill 1985). In the Gulf of Moxico, $48 \mathrm{ppm}$ is the allowable nonthly average oil and grease concentration in produced water (Final NPDES Ceneral Permit 1986). As the anount of water increases vith the production of crude oil, these necessary environaental standards aay, unfortunately, liait the econonies of this industry. Therefore, a clear need exists for an officient oily water cleanup systen for offshore production of oil (Hayes 1985; Koons, UcAuliffo and Weiss 1978).

For the past 29 years, Thew and his coworkers at Southanpton University (UK) have been developing inprovements to the hydrocyclone for de-oiling water (Colman and Thew 1989, 1983, 1984; Colman, Thew and Corney 1989; Nezhati and Thew 1987). The hydrocyclone is well established in the chenical, food, and wineral industries as an 
inertial separator or classifier of solid particles (Bradley 1965; Svarovsky 1984). Now, because of Thew's offorts, it is also beconing an acceptable alternative to other unit operations as a liquid-liquid separator.

Because ianiscible fluids generally have low relative densities, very intense swirling flows are needed to separate a finely dispersed liquid phase by centrifugal action. Centrifugal acceleration is produced nithin a hydrocyclone by introducing the feed strean tangentially into a conical device under high pressure (see Figure 1.1). The kinetic energy of the feed is large and the flow is turbulent. Fluid shear may break up large drops into saller drops and, in some cases, may oven cause a "stable" enulsion to form (Bradley 1985; Robertson et al. 1984). This phenemenon, probably wore than any other factor, has linited the videspread use of hydrocyclone technology for liquid-liquid separation.

In a hydrocyclone used to separate snall amounts of oil fron weter, the dispersed oil phase wigrates toward the axis of the swirling flow field and is reaoved with the overflow strean. In the Southampton design, the

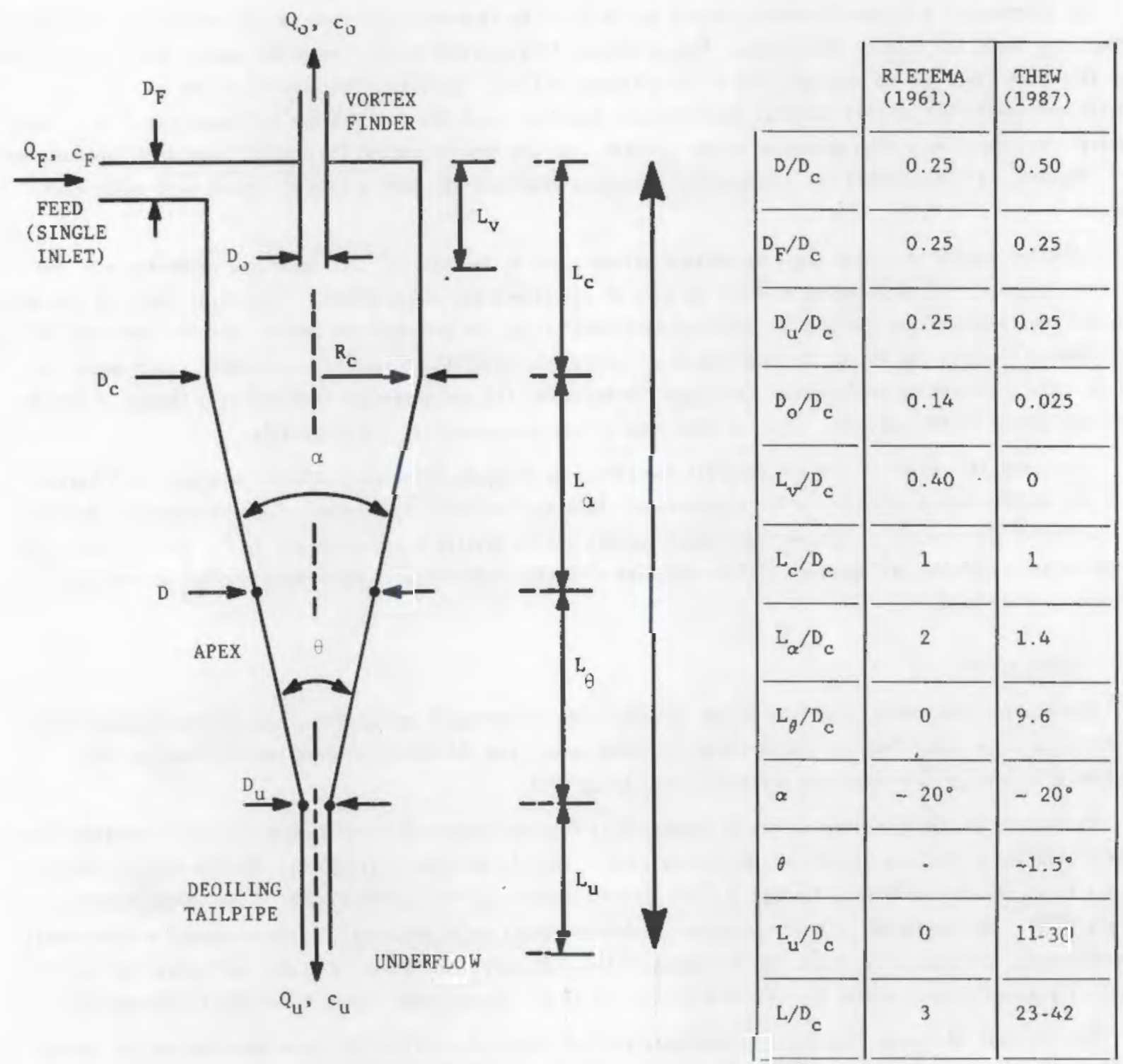

FICURE 1.1. Conventional Hydroclone Ceometry for De-oil ing Water 
overflow ratio $Q_{0} / Q_{F}$ may be as amall as $\mathbf{0 1}$. Back pressure on the overflow and underflow effluent streams is necessary to prevent air entrainment into the oil phase. In this situation, unlike many other applications of hydrocyclones, an air core does not appear on the axis of the vortex. Instead, large jet-like countercurrent axial flows develop between the vortex finder and the apex region, depending on the aagnitude of $Q_{0} / Q_{F}$ (see $D_{a b i r}$ 1983; Chen 1987).

The potential of hydrocyclones for separating a light dispersed phase fro a heavy continuous phase is explained by equating the residence time of a droplet in the suirling flow to the tive needed for the droplet to nigrate to the axis (Van Rossun 1953; Listewnik 1984). For purposes of illustration, suppose the flow within the hydrocyclone chamber is a 'free' vortex with a uniform axial velocity. The tangential and axial components of the mean velocity are

$$
\begin{aligned}
& \left\langle u_{\theta}\right\rangle=u_{F} R_{c} / r \\
& \left\langle u_{z}\right\rangle=q_{u} / A_{u}
\end{aligned}
$$

where $u_{F}=$ bulk average velocity of the feed $\left(Q_{C} / \Lambda_{F}\right)$

$\hat{A}_{F}=$ cross sectional area of the tangential inlet tube

$A_{u}=$ cross sectional area of the axial underflou effluent tube

$R_{c}=$ radius of the hydrocyclone chamber at the feed entry

$r=$ radial distance fron the axis of the vortex field.

If the local centrifugal force acting on a liquid drop is balanced by viscous drag, then the drift velocity of the dispersed phase is

$$
u_{D}=\frac{\ell^{2}\left(\rho_{D}-\rho_{c}\right)\left\langle u_{\theta}\right)^{2}}{18 \mu_{c}{ }^{r}}
$$

where $\ell=$ dianeter of the liquid drop

$\mu_{c}=$ viscosity of the continuous phase

$\rho_{D}=$ density of the dispersed phase

$P_{c}=$ density of the continuous phase

$r=$ radial distance fron the axis of the vortex fiold.

Because $\rho_{0}<\rho_{c}$ for a "light" oil in water, $u_{0}$ is negative and the dispersed phase nigrates tovard the axis of the swirling flow.

An explicit relationship between the particle size wich has onough tive to aigrate to the axis of a vortex of length $L$ follows by combining Equations (1) through (3). If $A_{U}=A_{F}$ and $Q_{U}=Q_{F}$ (de-oiling water), the resulting analysis yields

$$
\left(\frac{R^{*}}{R_{c}}\right)^{2}\left(1-\frac{P_{D}}{P_{c}}\right)\left(\frac{\varphi_{c}^{u_{F}}}{\mu_{c}}\right)=4.5
$$

where $L=$ length of the vortex

$$
l^{*}=\text { dianeter of a particle which starts at }(r, z)=\left(R_{c}, \theta\right) \text { and wigrates to }(r, z)=(\theta, L) \text {. }
$$


Figure 1.2 shoms the behavior of Equation (4) for paraneters that are characteristic of de-oiling water in the Southaupton hydrocyclone (i.e., $R_{c}=35 \mathrm{~mm}, L / R_{c}=46$ ). For $u_{F}=3.5 \mathrm{~m} / \mathrm{s}$ and $D_{c} / D_{F}=4$, the Reynolds nuaber for the flow in the tangential inlet tube is 61,25 . Obviously, the flow is highiy turbulent for volumetric flow rates of industrial interest $\left(Q_{F}=50 l / a i n\right)$.

Because particles smaller than $\mathcal{l}$ do not have onough tine to reach the axis, the probability that they will be renoved with the reverse flow strean decreases significantly. Equation (4), reported here for the first time, is consistent with the observed performance of the Southampton hydrocyclone under laboratory as well as field conditions (Thew 1984, 1987). Thus, for a fixed value of $U_{F}$, the equation helps to explain why de-oiling hydrocyclones must be longer than conventional hydrocyclones in order to capture particles as small as 50 aicrons. However, Equation (4) stens froe an oversimplified view of the flow and does not include inportant hydrodynaaic phenomena associated with the viscous nature of the vortex core or the offect of turbulence on droplet breakup and dispersion.

The conclusion from Equation (4) that the separation officiency can be increased for a fixed value of $u_{F}$ by siaply increasing $L / R_{c}$ ay be visleading. Experiaental and theoretical studies of vortex flows operating vithout air cores indicate that near the axis an outward radial flow occurs (Dabir 1983; Chen 1987). Therefore, because of viscous drag, very fine oil droplets may be unable to penetrate the core of the flow field even for very long reaidence tiess. This phenemenon, illustrated by Figure 1.3, partly motivates the proposal that the dispersed phase should be introduced closer to the axis of the vortex (see Section 1.2).

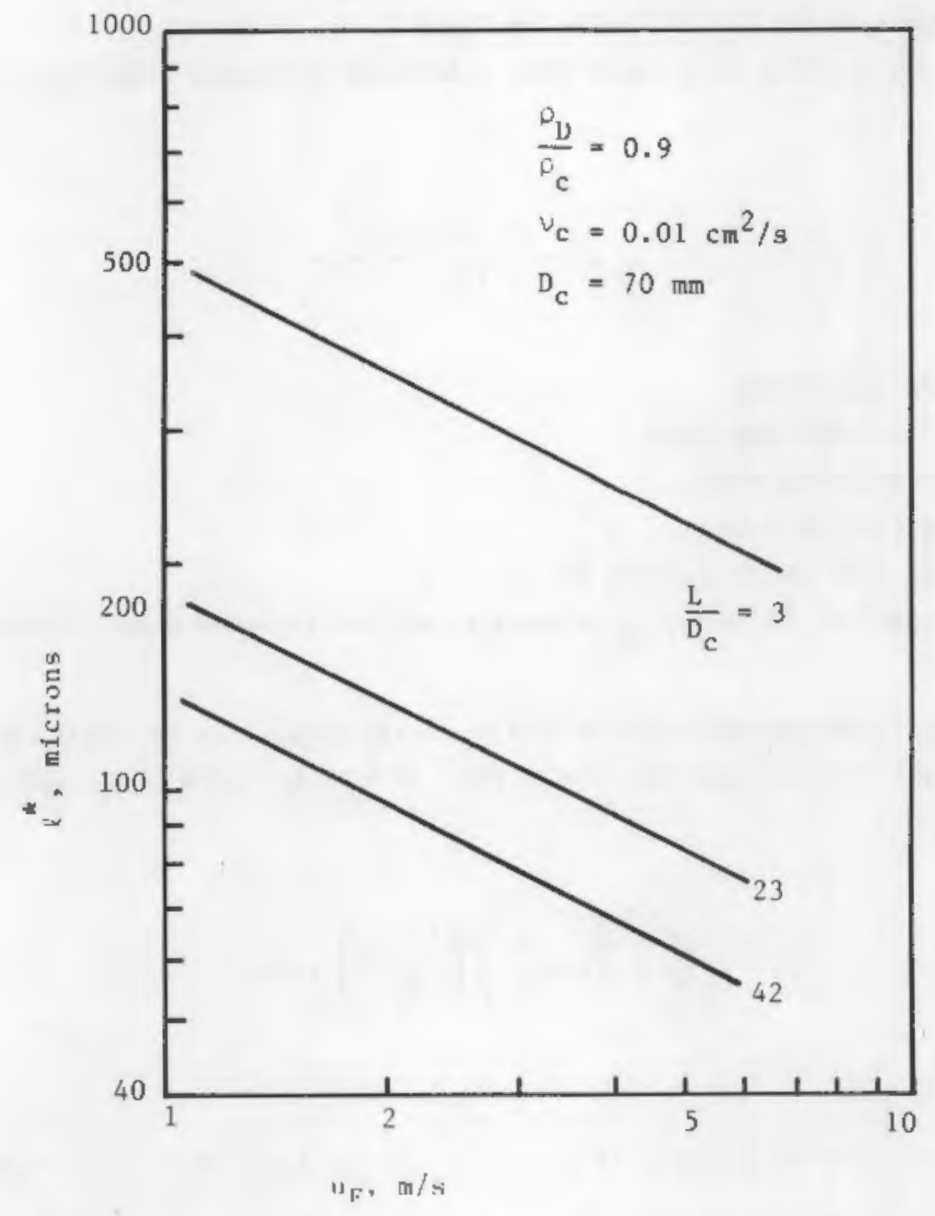

FICURE 1.2. Critical Separation Size Based on Particle Residence Tine ithin A Free Vortex 
For $r \gg 0$,

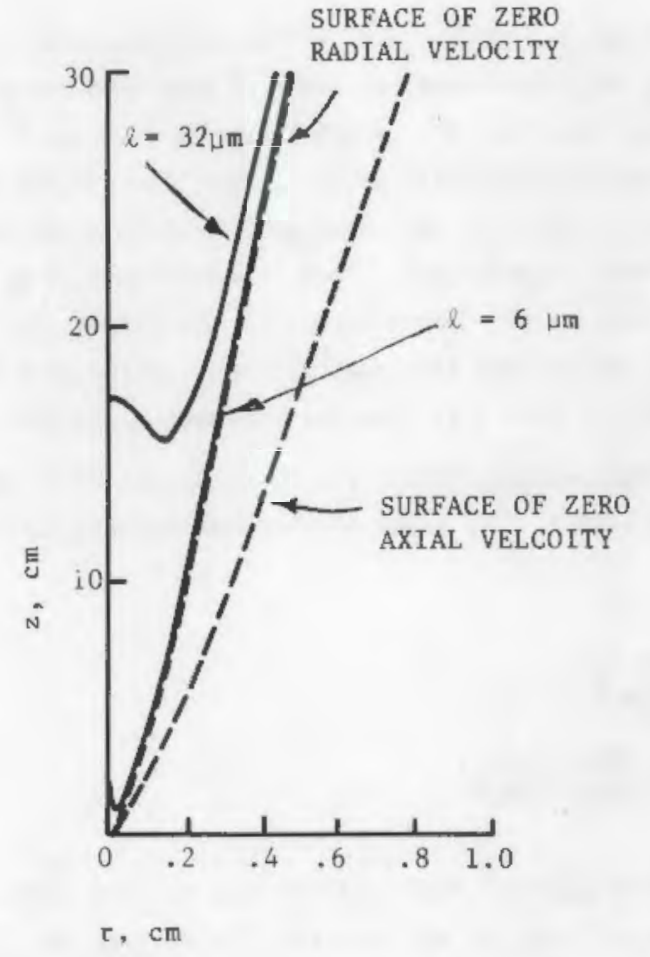

$\left\langle\mathrm{u}_{\theta}\right\rangle=\mathrm{Kr}^{\mathrm{N}}$.

$$
\mathrm{N}=-0.75
$$$$
\mathrm{K}=500 v_{e}, \operatorname{cm}^{1-\mathrm{N}} / \mathrm{s}
$$$$
v_{e}=10 \nu \text {, 'eddy' viscosity }
$$$$
\nu=0.01 \mathrm{~cm}^{2} / \mathrm{s}
$$$$
\rho_{D} / \rho_{C}=0.9
$$

NOTE: These calculations illustrate the classification action of a viscous vortex. At $z$ $10 \mathrm{~cm}, \mathrm{am}$ particle is located at $\mathrm{r}-0.2 \mathrm{~cm}$, whereas a $32 \mathrm{~m}$ particle is on the axis $(r-g)$. For $z>25 \mathrm{~cm}$, the particles are no longer separated. [Based on a sinilarity solution to the Navier-Stokes equation for jet-like flow (p. 168, Chen 1987)].

FICURE 1.3. Droplet Equilibrium Orbits vithin a Viscous Vortex

Although the hydrocyclone is a relatively siaple and inexpensive unit operation, its perforance as a Iiquid-liquid separator is directly affected by four syndromes:

1. large-scale secondary flows that renix the separated dispersion

2. turbulent fluctuations that cause renixing and drop breakup

3. an inverse relationship between the separation force and the tiac available for separation

4. particle equilibriue orbits within the core of the vortex.

Many variations in the basic design of hydrocyclones have been introduced to conpensate for one or more of these factors (Bednarski and Listewnik 1987; Thew 1987). The elininated the large-scale secondary flows in the upper part of the hydrocyclone by using a larger than 'noral' swirl chanber and a tangential feed with a lover kinetic energy (see Figure 1.1). This also lowers the turbulent intensity at entry.

To compensate for the lower centrifugal force, the conical section of the Southanpton design, which anplifies the swirl component of the flow, is much longer than conventional hydrocyclones used for other separation problens. However, the flow reaains turbulent and large oil droplets can still be torn apart by turbulent fluctuations. Therefore, because of the phenowenon illustrated by Figure 1.3 and because turbulence always produces a fine dispersion of drop sizes, the modified design of Thew has unavoidable intrinsic liaitations. A different approach is needed to sinultaneously resolve the above syndromes of hydrocyclone technology for liquid-liquid separations. 


\subsection{ASSESSUENT OF THE CONCEPT}

A sall anount of polyethylene oxide in water ( $<160$ wppe) has a significant effect on the properties of turbulent flows (Virk 1975; Sellin and Uoses 1984). For small capillary tubes, an order of magnitude reduction in the friction factor can occur; for larger pipes of industrial interest, the offect is saller but still significant. Generally, any linear, flexible, nacronolecule having a nolecular weight larger than 596,000 is an offective drag reducer in dilute solutions. Although the specific physical mechanisn underlying this phenosenon renains unclear, the practical consequences are clear: turbulence is noderated. Thus, trace anounts of polyner injected into the core region of a flooded (no air core) hydrocyclone nay dampen turbulent fluctuations that cause liquid drops to break into smaller drops. Horeover, the polymer may also stabilize the central core flow and, thereby, perwit even saller overflow ratios (i.e., $q_{0} / q_{f}$ in Figure 1.1) than the Southampton design.

Liquid-liquid separations in swirling flows way also be iaproved significantly by oxploiting more directly certain flow patterns that develop within the core region of a vortex. For exanple, when the characteristic soirl number, def ined by

$$
S=\frac{\left(\begin{array}{l}
\text { NXINL FLUX OF } \\
\text { SWIRL MOMENTU }
\end{array}\right)}{\left(\begin{array}{l}
\text { NXINL FLUX OF } \\
\text { NXIN MOMENTUN }
\end{array}\right)\left(\begin{array}{c}
\text { TRANSVESE } \\
\text { LENGTH SCNLE }
\end{array}\right)}
$$

is large, the radial and axial pressure gradients cause a central toroidal recirculation zone to fora (Gupta, Lilley and Syred 1984). Figure 1.4 shows the effect of $S$ on a swirling jet and on a suirling annular jet. The phenomenon shown is widely exploited to stabilize conbustion flames, but is generally avoided in conventional cyclone separators.

Another pervasive feature of swirling flows is their large resistance to contractions compared with their non-swirling counterparts. A vortex valve exploits this fact by injecting a seall secondary (or control) fiow tangentially into a conduit and allowing the flow to contract radially (Lerellen 1971). The swirling action of the fluid is anplified because of a tendency to preserve angular mosentum. Thus, a large back pressure develops within the valve and the flow rate decreases significantly. A hydrocyclone, which obviously has a different

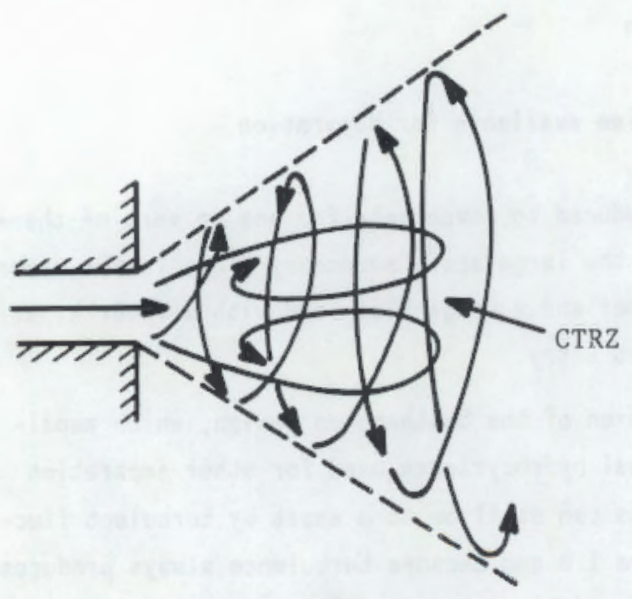

SWIRLING JET FLOW $(\mathrm{S}>0.6)$

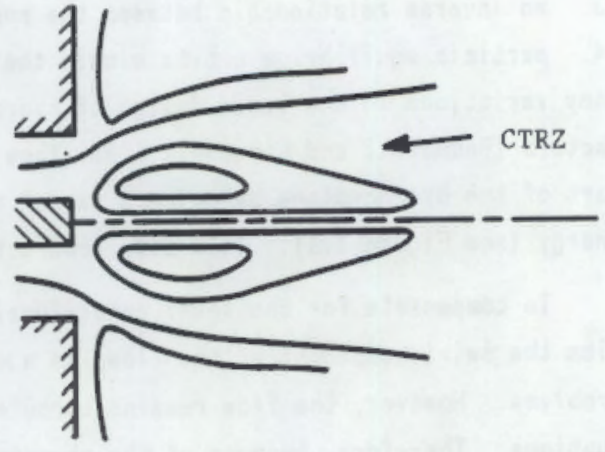

STREAMLINES IN A SWIRLING ANNUI AR JET $(S>1)$

FICURE 1.4. Central Toroidal Recirculation Zone (CTRZ) at High Svirl Nunbers (Gupta, Lilloy and Syred 1984) 
function than a flow valve, can be viewed as a vortex valve vith the entire foed strean being used as the "control' flow component. Is this the nost energy officient way to operate a hydrocyclone for liquid-liquid separations?

In the following sections, the proposed concept is described, and its technical foasibility, benefits, and status are discussed.

\subsubsection{Description of the Concept}

The purpose of this study is to introduce and to partially evaluate the potential of a new separation coneept for de-oiling water that exploits directly sone unique flow structures within vortex flows. The goal is to

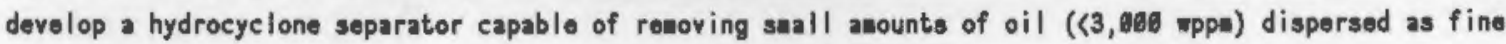
droplets in water.

Figure 1.5 illustrates a new approach to liquid-liquid separation when the dispersed phase is lighter than the continuous phase (oil in water). The proposed method attenpts to exploit two unrelated physical offects: 1) some novel secondary flows at high swirl numbers, and 2) the ability of high nolecular woight polyners to reduce turbulent fluctuations.

For a light dispersed phase, a liquid droplet in the vortex field tends to move toward the axis until it encounters its equilibriun orbit (see Figure 1.3). The conventional approach is to introduce the entire feed tangentially into the outer region of the flow in order to drive the vortex. Thus, the wajor operating cost of this unit operation is associated vith the large pressure drop (centrifugal head) needed to inject the feed into the 'f ree' vortex region of the flon field. This strategy aay be unnecessary for good separation of a light dispersed phase. The new approach suggested by Figure 1.5 is to introduce the feed closer to the axis of the vortex as a suirling annular jot while using a particle-free control flow to supply supplenental onergy to the vortex. Like the vortex valve and the conventional hydrocyclone, the swirling action of the confined flow is anplified by using a conical geonetry.

For large swirl nubbers, separation of the light dispersed phase fron the continuous phase occurs in three zones: A) within the annular feed tube, B) within the central toroidal recirculation zone at the ontry of the overflow effluent tube, and C) within the contraction zone of the flow field near the underflow offluent tube. To control the turbulent fluctuations within the vortex core, sall anounts of a high molecular wight polynor (such as polyethylene oxide) ean be injected into the reverse jet-like flom running fron the apex toward the central toroidal recirculation zone. By reducing the intensity of turbulence within Zone C (see Figure 1.5), we anticipate that larger drops can fore by coalescence, that the vortex core way be less susceptible to breakdown, and that the rate of energy dissipation within the core region vill be lower.

The above concept, which represents a combination of several ideas, vill have its own unique set of liniting syndromes, yot to be identified. However, the proposed device atteupts to address two specific problens associated with separating a fine suspension of a light liquid phase fron a continuous liquid phase with a sall difference in denaity (i.e., oil in vater):

- the need for a large centrifugal acceleration

- the need to control drop breakup by turbulent fluctuations.

The first problem is approached by introducing the dispersed phase nearer the point of ultimate separation (see Figure 1.5), whereas the second problen is approached by using friction-reducing polyners.

\subsubsection{Technical Feasibility}

The technical feasibility of the new centrifugal separator is discussed below in terns of its piggyback configuration, central toroidal recirculation zone, polymer injection, and poner requirements. Also, impediments to videscalo use and potential narkets for the concept are discussed. 

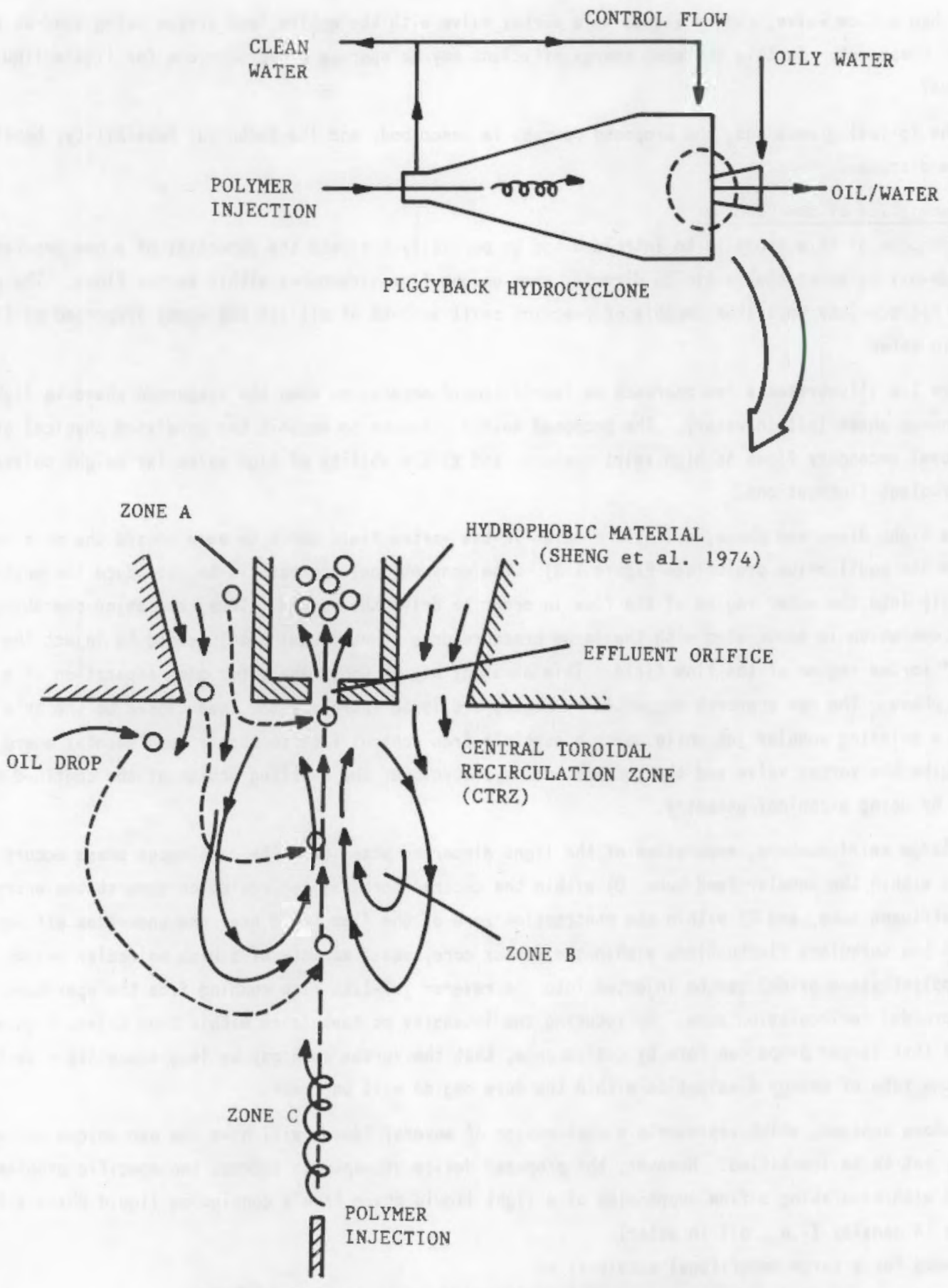

FICURE 1.5. Schenatic of the New Separation Concept

\section{Piggyback Conf iguration}

One of the siaplest measures of separation performance is the fraction of oil removed froe the foed:

$$
\epsilon_{u}=\frac{q_{F} c_{F}-q_{u} c_{u}}{q_{F} c_{F}}=1-\frac{c_{u}}{c_{F}}
$$


The de-oiling hydrocyclone developed at Southanpton University (see Figure 1.1) gives $\epsilon_{u}=6.85$ for conditions of comercial interest (Thew 1984, 1986, 1987). In the absence of droplet breakup phenomena, the overall separation officiency can be increased to $98 \mathrm{x}$ by using a second stage. This way not be practical if the underflou strean from the first stage must be repressurized.

Although the separation concept def ined by Figure 1.5 has not been evaluated yet, we expect $\epsilon_{u}=0.97$ for a single pass under the same conditions for which the nore conventional design gives $\epsilon_{u}=0.85$. The reason for this is that the piggyback configuration of the new design has three diatinet zones of separation: prinary (Zone A), secondary (Zone B), and tertiary (Zone C). Because the "light" phase always drifts toward the axia, this strategy for introducing the feed into the vortex chanber should give an equivalent two-stage offect. The primary separation of the oil droplets within the annular feed tube could be enhanced further by using a hydrophobic material for the vortex finder (Sheng, Velker and Sliepeevich 1974). We are hopeful that the geonetric scales of the proposed design can be selected to reduce the concentration of oil from 1,600 wppn to 30 wppn with only a single pass through the separator (see Section 1.3.1).

\section{Central Toroidal Recirculation Zone}

Separation Zone B occurs for large swirl numbers (see Figure 1.2). The suggestion that this secondary flov can capture oil droplets and direct thea toward the vortex finder orifice is intriguing, but speculative. The strength of this strategy aust be evaluated carefully because the potential for drop breakup vithin the central toroidal recirculation zone seens likely. On the other hand, this secondary flom may provide a positive stabilizing influence on the vortex core and, thereby, perait a lower effluent ratio $Q_{0} / Q_{F}$.

\section{Polyaer Injection}

The Gulf of Mexico oil fields produce nearly $800,960 \mathrm{bbl} /$ day of water and about the sane anount of oil (Burke 1985). Therefore, because of the large amounts of water produced on offshore platforms, it is important to deteraine the most offective way to use friction-reducing polyners for turbulence control. The strategy proposed here attempts to dose only the reverse flow portion of the flow field $(: 0.1 \mathrm{q})$ were the turbulence dissipation rate is highest. If the polyner cost 83 per $\mathrm{Ib}$, then the cost for cheaicals needed to dose

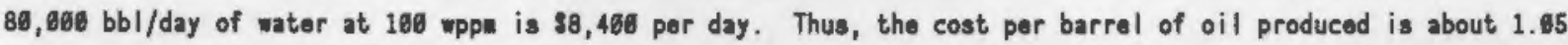
conts. Obviously, if friction-reducing polyners can prevent drop breakup, then the polyner should be introduced into the flow field where it has the largest iapact.

\section{Power Requireaents}

Because the centrifugal head deterwines the pressure drop across a hydrocyclone (Bradley 1965), the power required by the new separator may be less than the power required by the more conventional approach (Figure 1.1). The conjecture here is that the piggyback configuration needs a saaller centrifugal acceleration to achieve the sane degree of separation. However, this feature has not yet been denonstrated.

\section{Impediments to Tidespread Use}

Because of the high shear fields vithin hydrocyclones, breakup of drops can occur. This phenomenon has prevented the widespread adoption of the hydrecyclone for liquid-liquid separation. Careful design of the entry region and the initial swirl chanber (see Figure 1.1) provides sone improvenents. However, at very high flow rates, intrinsic turbulent fluctuations can still decrease the mean particle dianeter and form a 'stable' enulsion. The use of a polymer additive to prevent drop breakup complicates the unit operation. Continuous injection of a concentrated polywer solution into the core and subsequent wixing with the fluid in Zone $C$ (see Figure 1.Б) aay upset the flow patterns and the anticipated separation of fect.

Friction-reducing polywers are expensive ( $\$ 1$ to $\$ 3$ per Ib). If the process feed rate is large, then adding enough polyner to the entire foed to wake a 100 uppa solution would be too costly and wastoful. Local injection 
of polywer into Zone $C$, although awkward, reduces the quantity of chenicals needed by an order of agnitude. Polyothylene oxide and polyacrylanide are al ready used as flocculating agents in waste water treataent facilities. At low concentrations, these chenicals have a negligible inpact on the environuent (Dow 1975; Union Carbide 1985). Thus, by using a local injection strategy in which only 10x of the feed rate is treated with polymer, the back-aixed concentration of polyner in the clean water will be much less than 100 wpp.

\section{Potential Markets}

The separation concept described in Section 1.2.1, if feasible, would have an inmediate inpact on cleaning oily water on offshore platforas. Three companies anufacture hydrocyclone type equipment for this application: BirN (Australia), Serck Baker (UK), and Alsthon (France). Recently, BuN purchased the Oilspin (a) technology of Serck Baker (1984). The Vortoi $\mathcal{F}$ (b) (BaN 1987) and Oilspin designs sten directly fron the Southanpton work. Alsthon (1987) uses a rotary de-oiling cyclone (Dynaclean) $(c)$ which is a hybrid between a centrifuge and a cyclone. The reported separation officiency of the rotary separator is higher than the more conventional hydrocyclone design (Figure 1.1) presunably because spin-up of the fluid mass is gentle (Gay et al. 1987).

If the piggyback design (see Figure 1.5) together with the central toroidal recireulation zone causes the separation of very fine oil droplets $(\langle 3 \sigma \mu)$, then this new conpact separater could also be used to elean bilge and ballast water on ocean vesseis as wall as other waste streans presently being cleaned by more castly unit operations.

\subsubsection{Benofits of the Ner Concept}

As a compact separater, the hydrocyclone offers many new opportunities for liquid-liquid separations (Goldberger 1973). Depending on the specific application, it would either conpete with, or conplenent, other technologies such as gravity separators, filtera, parallel plate coalescera, gas flotation, and centrifuges (Wyer, Van Cleave and Biglane 1975). Possible, yet unproven, benefits of the specific concept shown by Figure 1.5 relative to the hydrocyelone shown in Figure 1.1 are as follows:

- stable drop-size distribution - This any result by using polyeers to decrease the turbulent intensity and by introducing the dispersion into the vortex chamber at a lower pressure.

- lower overflow ratio - This may result by introducing the foed as an annular jet and causing a central toroidal recirculation zone to forn near the overflow orifice.

- higher officiency per stage - This may occur because the piggyback configuration provides three zones for separation.

- flexible turndown characteristies - The use of a control flow component to supplenent the energy needed for the vortex action partly uncouples the feed rate from the separating force.

- lower power requirements for equivalent separation perfornance - This may occur because the dispersion is introduced closer to the point of ultinate renoval of the "light" phase.

\subsubsection{State of the Art}

Sinkin and Olney (1956) studied liquid-liquid separation in a $95 \mathrm{~mm}$ hydrocyclone of conventional design. They exanined the effects of geometry and split ratio $\left(q_{0} / q_{y}\right)$ on the separation efficiency of oil and water dispersions. The feed concentration of oil ranged from 25 to $90 \mathrm{vol} . \mathbf{x}$, and the mean dianeter of the dispersed phase ranged from 1 to $2 \mathrm{mn}$. The noninal feed rate was 38 l/min, which gives a Reynolds number based on the feed dianeter of over 46,900. Obviously, the liquid drops dispersed in this continuous phase experienced a vide range of turbulent fluctuations, and because the separation efficiency decreased significantly when the volune of the

(a) Oilspin is a registered trademark of Serck Baker, Gloucester, England.

(b) Yortoil is a regiatered tradomark of BNN, Dandenong, Yietoria, Australia.

(c) Dynaclean is a registered trademark of Alsthon, LePont de Claix, France. 
hydrocyclone was increased, Sinkin and Olney concluded that drop breakup due to turbulence within the hydrocyelone controlled the separation perforance rather than drop trajectory and residence time (Figure 1.2).

Unfortunately, because of the high concentrations used in the experients, nost of the experimental data from Sinkin's and Olyney's study (1956) fall very near the coalescence curves, which wakes a clear interprotation of these experinents difficult. Siakin and Olney also concluded that liquid-liquid separation for drop sizes less than 1,060 an would be ineffective in a hydrocyclone over the range of concentrations studied.

Using a 51 m hydrocyclone, Burrill and Woods (1970) successfully separated liquid drops of carbon tetrachloride dispersed in water with mean diameters ranging fron 150 to $360 \mu\left(\rho_{0}>\rho_{c^{\prime}} \mu_{0}=\mu_{c}\right)$. The foed concentration was rather high (12 to 17 vol\$); and over a range of split ratios from 4 to 8 , Burrill and Woods concluded that a "hindered" discharge mechanism was controlling the separation officiency. Although the ieportance of the split ratio on the internal flon structures was apparently not recognized by either Burrill and Woods or by Sinkin and Olney, both research groups underscored the significance of making comparison studies between different systens at their individual "optieal' split ratios. For very dilute systens, an 'optimal" split ratio induced by hindered discharge conditions is not an iaportant consideration. However, as enphasized by Ther and comorkers (see, especially Colman and Thew 1989) and by Dabir (1983), an optimal ratio of $Q_{0} / Q_{u}$ for flooded conditions (no air core) way occur because of changes in the basic flon structure within the core of the hydrocyclone.

For the past 20 years, Thew and his students at Southampton University have pioneered the use of hydrocyclones for separating very dilute suspensions of oil in water $\left(\rho_{D}<\rho_{C}, \mu_{D}=\mu_{C}\right)$. This extensive developnent progran has been reviewed by Thew (1987). To stabilize the central vortex core region within the hydrocyclone, the Southanpton group developed a hydrocyclone with a co-axial vithdrawal of liquid through the vortex finder. ॠith this modification, they were able to increase the concentration factor for Kumait crude $\left(\rho_{D}=0.87 \mathrm{~g} / \mathrm{ca}^{3}\right.$; mean particle size, $41 \mathrm{~m}$; flow rate, $80 \mathrm{~h} / \mathrm{ain}$; feed concentration, 1,060 ppm) fron $20: 1$ to $180: 1$ in a $30 \mathrm{~mm}$ cylindrical hydrocyclone (Colman and Thes 1980). Many other variations in the geonetric scales have appeared since this earlier success and the 8-fold improvenent in performance indicated above has been superceded by other designs (see Figure 1.1) that further reduce the turbulence intensity levels as well as stabilize the vortex core.

Thonas, Dabir, and Petty (1984) confirned and extended the earlier findings of Vallace, Dabir, and Petty (1980) that the centrifugal efficiency of separating kaolinite clay (sean size of $1 \mu$ ) in a 10 androcyclone inereases significantly in the presence of Separan AP-30. Floceulation of clay particles certainly occurs in the presence of this polyner, but this phenonenon alone cannot fully explain the results obtained.

In the absence of a particulate phase, Dabir (1983) initiated an experimental study of the offects of polyacrylanide on the secondary flon structures in hydrocyclones. He measured the mean velocity field within a $3^{1}$-hydrocyclone operating without an air core. By using a flow visualization technique and a laser doppler anemoseter, his results have provided new insights and have raised many interesting questions regarding the flow patterns within a hydrocyclone having the sane geonetric sealos doveloped earlier by Riotena (1961) for 'optiual' perforance under solid-liquid separations.

Dabir (1983) also investigated the effect of Separan AP-38 on the core flow in a $3^{\prime}$-hydrocyclone. He concluded that the polymer causes the dampening of volocity fluctuations within the central core region with the result that the shear conponent of the Reynoids stress has been reduced threefoid. Thus, the addition of a high molecular weight polyner in saall anounts may provide a novel way to roduce the breakup of oil droplete when finely dispersed oil in water is being separated in a hydrocyclone. This result may also have an iaportant effoct on the "sharpness-of-separation" in a classification operation. 


\subsection{FUTURE CONCEPT DEVELOPMENT}

The imsediate steps needed to further develop the new centrigual separator are discussed below, followed by the additional steps needed for the concept's ridespread use.

\subsubsection{Inmediate Steps Required}

The concept shown in Figure 1.5 is presently being tested in a prototype vortex chanber. Preliminary results vill be presented at the technology fair in May. However, the technical merits of the separation concept as currently perceived should be compared quantitatively with current hydrocyclone technology for de-oiling water (see Figures 1.1 and 1.5).

A comparison study should focus on a specific separation problea such as kerosene in water or vegetable oil in water. The dispersed phase should be dilute $(\langle 3,000 \mathrm{mppn})$, and the mean drop size in the feed should be between 50 to $100 \mathrm{~m}$. The effect of flow rate and split ratio on the separation efficiency $\epsilon_{u}$ [see Equation (5)] should be measured for a wide range of feed compositions (1,600 to 3, 600 wppw). The laboratory-scale evaluation should be designed for feed rates of comnercial interest $\left(\mathbb{R}_{F}=50\right.$ to $\left.106 \mathrm{l} / \mathrm{min}\right)$. The two vortex chanbers should be constructed of optically clear material so major differences in flow structure for sinilar feed rates and split ratios can be observed.

The ability of polymer additives (either polyethylene oxide or polyacrylanide) to reduce droplet breakup and, thereby, increase $\epsilon_{\mathrm{u}}$ for both hydrocyclones should be evaluated under sinilar operating and foed conditions. To aininize the anount of polymer consuned, the feasibility of polyner injection directly into the core region, where the turbulence dissipation rate is highest, should be ovaluated for both designs.

Although the new separation concept rotains the advantages of no moving parts, the side flow control makes the proposed design nore complicated than the Southanpton design. We anticipate that this feature can be exploited to increase $\epsilon_{u}$ without a significant power requiresent. Obviously, this conjecture must be demonstrated prior to commercial acceptance of this strategy.

\subsubsection{Additional Steps Needed for Videspread Use}

Ve have completed two major studies on the hydrodynanies of hydrocyclone flows: one experinental (Dabir 1983) and another theoretical (Chen 1987). The separation concept proposed here (Figure 1.5) stens fron insights developed frow this earlier research. However, widespread acceptance of turbulent vortex flows as a mediun for liquid-liquid separations requires a better understanding of droplet breakup phenonena. The effoct of turbulence production rate, the molecular viscosity, surface tension, drop size, and particle concentration on the rate of drop breakup within a turbulent vortex has not been quantified. Fortunately, fundanontal studies in this area can now be developed using laser doppler anenometry and in situ particle sizing by laser light scattering. Both of these research tools have appeared since the pioneering and influential work of Sinkin and Olney more than thirty yoars ago.

\subsection{REFERENCES}

Alsthon. 1987. Dynaciean? Technical Bulletin, Alsthon, LePont de Claix, France.

Bednarski, S., and J. Listemik. 1987. "Hydrocyclones for Sinultaneous Removal of Oil and Solid Particles from Ships' Oil Water." In Proceedings of the Third International Conference on Hydrocyclones, P. 181, ed. P. Mood, Elsevier, London.

Bradley, D. 1965. The Hydrocyclone. Pergazon, New York.

Burke, R. G. Septenber 1885. 'Cleanup of Oily later Poses a Challenge.' Offshore. Pennlloll Publishing Company, Tulsa, Oklahoma.

Burrill, K. A., and D. R. Woods. 1970. "Separation of Two Inniscible Liquids in a Hydrocyclone." Ind. Eng. Chen. Process. Des. Devolop. 9:545. 
Bur. 1987. "Yortoil. Technical Bulletin, B.W.N., Dandenong, Victoris, Australia.

Chen, Hsiu-Chih. 1987. 'Similarity Structure of an Axisymetric Viscous Vortex with Variable Cireulation," Ph.D. Dissertation, Wichigan State University, East Lansing, Nichigan.

Colman, D. A., and M. T. Thew. 1980. 'Hydrocyclone to Give a Highly Concentrated Sanple of a Lighter Dispersed Phase.' In Proceedings of the First International Conference on Hydrocyclones, p. 209, eds. O. Priestley and H. S. Stephens, BHRA, Cranfield, Bedford, England.

Colean, D. A., and U. T. Thew. 1983. 'Correlation of Separation Results from Light Dispersion Hydrocyclones." Chen. Eng. Res. Des. 61:233.

Colman, D. A., and U. T. Then. 1984. The Concept of Hydrocyclones for Separating Light Dispersions and a Comparison of Field Data vith Laboratory Iork." In Proceedings of the Second International Conference on Hydrocyclones, P. 217, ed. R. Pickford, BHRA, Cranfield, Bedford, Ergland.

Colman, D. A., U. T. Thew and D. R. Corney. 1984. "Hydrocyclones for 0il/Water Separation." In Proceedings of the First International Conference on Hydrocyclones, p. 143 eds. G. Priestloy and H.S. Stephens, ERRh, Cranfield, Bedford, England.

Dabir, B. 1983. 'Wean Yolocity Weasurenents in a 3'-Hydrocyclone Using Laser Doppler Anenowetry.' Ph.D. Diasertation, Uichigan State University, East Lansing, Uichigan.

Don Chenical Conpany. 1975. 'Separan Polyeers Settle Process Problens." Technical Bulletin, The Dow Chenical Company, Midland, Michigan.

"Final NPDES General Pernit for the Outer Continental Shelf (OCS) of the Gulf of Loxico," Fed. Reg. 51, 131, 24897 (1986).

Gay, J. C., G. Triponey, C. Bezard and P. Schumner. 1987. 'Rotary Cyclone Vill Improve Dily Iater Treatment and Reduce Space Requirement/Weight On Offshore Platforns." Offshore Europe 87, Aberdeen 8-11 Sept. (1987). SPE 16571 .

Coldberger, 1. M. 1973. 'Liquid-Liquid and Solid-Solid Systens.' Section 21, Chenical Engineers' Handbook, 5th Edition, eds. R. H. Perry and C. H. Chilton, HeGraw-Hill, Nen York.

Gupta, A. K., D. G. Lilley and X. Syred. 1984. Swirl Flows. Abacus Press, Canbridge, Massachusetts.

Hayes, J. J. 1985. 'Bass Strait Iater Handling Devolopments." The APEA Journal. p. 114.

Hayes, J. J., T. C. Carroll and D.W.J. Fothergill, 1985. 'Hydrocyclones for Treating Oily Vater: Development and Field Testing in Bass Strait." In Proceedings of the 17 th Annual Offshore Technology Conference, p. 549, Held in Houston, Texas.

Johnston, C. S., and A. R. Halliwall. 1976. 'Environnental Considerations in the Design of Ballast Water Outfalls." OTC 2446, Presented at Offshore Technical Conference, Dallas, Texas.

Koons, C. B., C. D. Uchuliffe and F. T. Weiss. 1976. "Environnental Aspects of Produced Waters froe Oil and Gas Extraction Operations in Offshore and Coastal Vaters." OTC 2447, Presented at the Offshore Tochnical Conference, Dallas, Texas.

Lerellen, I. S. 1971. 'A Reviev of Conf ined Vortex Flous.' NASA CR-1772.

Listewnik, J. 1984. "Sone Factors Influencing the Perfornance of De-oiling Hydrocyclones for Marine Applications." In Proceedings of the Second International Conference on Hydrocyciones, P. 191, ed. R. Piekford, BHRA, Cranfield, Bedford, England.

Lucas, R. S. 1976. 'Separation and Wonitoring of Oily Bilge Vater.' OTC 2206, Presented at the Offshore Technical Conference, Dallas, Texas.

Mezhati, X., and M. T. Thew. 1987. 'Aapects of the Perforance and Scaling of Hydrocyclones for Use vith Light Dispersions." In Proceedings of the Third International Conference on Hydrocyclones, p. 167., ed. P. Nood, Elsevier, Landon.

Rietena, K. 1961. 'Perfornance and Design of Hydrocyclones: I-IV.' Chen. Eng. Sci., 15:298.

Robertson, D. S., 日. J. Oswald, D. A. Colman and U. T. Thew. 1984. "Hydrocyclone for the Treataent of Oil-Spill Enulsions." In Proceedings of the Second International Conference on Hydrocyclones, ed. R. Pickford, BHRh, Cranfield, Bedford, England. 
Sell in, R.H.J., and R. T. Uoses. 1984. Drag Reduction '84. Third International IAHR Conference on Drag Reduction, July 2-4, 1984, Bristol.

Serck Baker. 1984. 'Oilspift. Technical Bulletin. Serck Baker, Glouceater, England.

Sheng, H. P., J. R. Velker and C. M. Sliepcevich. 1974. "Liquid-Liquid Separations in a Conventional Hydroeyclone." Can. J. Chen. Eng. 62:487.

Simkin, D.J., and R. 8. Olney. 1958. 'Phase Separation and Mass Transfor in a Liquid-Liquid Cyclone.' AIChE Journal. 2:545.

Svarovsky, L. 1984. Hydrocyclones. Holt, Now York.

Thew, M. T. 1984. "Pilot Scale and Field Trials of Oil-Water (Gas) Centrifugal Separators." In Proceedings of the 9th Lecture Series on Two-Phase Flow: Separation and Separators. p. 201, ods. L. N. Persen and N.T.H. Trondheis, Tapir Press, Trondheil.

Thew, M. T. July/August 1986. "Hydrocyclone Redesign for Liquid-Liquid Separation." The Chen. Eng. 17.

Thex, U. T. 1987. "Hydrocyclones for Liquid-Liquid Separation." Lecture 8, An Intensive Short Course, Oxford, 28-29 Sept. (1987). BHR, Cranfield, Bedford, England.

Thomas, G. E., B. Dabir and C. A. Petty. 1984. "The Effect of Drag Reducing Polyners on the Performance of Hydrocyclones." p. D.3-1 in Drag Reduction '84, IAHR, Bristol, England.

Union Carbide. 1985. "Polyox Nater-Soluble Polyners are Unique." Tech. Bulletin, Union Carbide Corporation, Danbury, Connecticut.

Van Rossua, J. J. 1953. 'Separation of Eaulsions in a Cyclone." 1st Syaposiun on Cyclones, Utrecht, 3rd June (1953), p. 110 in Cyclones in Industry, eds. K. Rietena and C. G. Verver. Elsevier, Nen York.

Virk, P. S. 1975. 'Drag Reduction Fundanentals.' AIChE Journal. 21:625.

Vallace, L. B., 8. Dabir and C. A. Petty. 1986. IPreliainary Findings on the Effect of Polyacrylanide on Particle-Liquid Separation in Hydrocyciones.' Ches. Eng. Connun. 7:27.

Wyer, R. H., H. D. Yan Cleave and K. E. Biglane. 1975. "Evaluation of Wastewter Treataent Technology for Offshore Dil Production Facilities." OTC 2232, Presented at the Offshore Technical Conference, Dallas, Texas. 


\subsection{EFICIENT RECOVERY OF FINELY DIVIDED MINERAL PARTICLES BY CENTRIFUGATION}

Kenneth N. Han

Department of Wetallurgical Engineering

South Dakota School of Vines and Technology

\section{ABSTRACT}

An efficient recovery of heavy and finely divided nineral particles from light gangue minerals has been investigated by imposing a delicate balance between centrifugal and surface tension forces on these particles.

A mixture of galena and silica fines of $460 / 500$ mesh size was used in this study as a nodel systen. Hydrophobic and heavy galena fines were separated easily fron hydrophilic and light silica particles in water/organic liquid under centrifugal force. Better than $90 x$ recovery $\mathbf{w i t h} 85 \mathrm{x}$ purity was possible in a two-liquid systen consisting of water and carbon tetrachloride with a centrifugal force less than ten times greater than the force produced by gravity. In the experiaents conducted, the of fect of surfactant concentration, different organic liquids, angular velocity, anount of organic liquid, and flow rate of slurry on the metallurgical efficiency of upgrading of galena was invostigated.

\subsection{INTRODUCTION}

The fineness of processing plant feed is increasing because of increased wine mechanization. Also, as the grade of ores diminishes, fine grinding is needed to liberate mineral matter before any upgrading operation can occur. Grinding is one of the most energy-intensive processes in mineral processing, consuming treatendous amounts of energy in producing fine particles. Unfortunately, the fine, potentially useful, mineral particles that are produced during the upgrading process and that exist in processing streans are not being recovered. Because of insufficient technology, mineral industries nationally and abroad are losing willions of tons of valuable winerals, such as clay wineral, iron taconite, tin oxide, and tungsten.

Another incentive for renoving fine particles is environmental. The renoval of suspended solids fron aine waste waters and effluent streans of mineral processing plants is a continuing environmental concern. The ineral industries generate more than $78 \%$ of the total suspended solid particles produced in the United States. Wore inportantly, however, is the mineral industries' rate of production of suspended solid particles. For exaaple, in 1975 about 47 aillion tons of suspended solids in nine waste streans were produced, and the projected production in 1985 (based on a 1980 prediction) was 144 uillion tons. Therefore, an urgent need exits to renove these suspended solid particles officiently at a reasonable cost.

Numerous suggestions and laboratory-scaie attempts have been made to recover such fine winerals by using various processing techniques such as flotation and flocculation. However, only a few of these techniques have proven to be econonically viable.

\subsection{CONCEPT DESCRIPTION}

A major inherent problen in treating fine particles is that their saall size makes it is extrenely difficult to remove fines fron the major streans of water flow. As the particles become saaller, density has less effect on the eotion of the particles. Consequently, separation of heavy particles from light particles because of gravitational force alone becones very difficult, if not impossible, for all practical purposes. Therefore, one of the most important factors affecting the upgrading of certain mineral particles is to have the motion of these 
particles under control. Sone industrial centrifuges can accelerate the notion of particles 60,000 times over that obtained with gravitational force alone. This investigation is aimed at recovering selectively useful, heavy, and hydrophobic mineral particles from light and hydrophilic gangue minerals by using controlled centrifugal forces and by introducing a heavy organic liquid mediun.

In this study, centrifugal force is used to control the sotion of finely divided particles of less than 37 microns (460 mesh). A prelininary study in our laboratory indicated that it was possible to produce an offective separation of galena particles (specific gravity=7.5) fron silica (specific gravity=2.65) using centrifugal forces only two to three times that produced by gravity. The key to this successful separation with such a low centrifugal force is in using the surface properties of these minerals together with an organic heavy liquid. Being a sulfide, galena particles are hydrophobic, while silica particles are hydrophilic.

When the mixture of these two aineral particles is introduced into a centrifuge containing two inaiscible liquids--water and heavy organic liquid--hydrophobic particles will pass through water and easily penetrato into the organic phase, while hydrophilic silica particles vill not easily cross the interface of the water/organic liquid. However, as the centrifugal force increases, silica particles will also be pulled into the organic phase as long as the density of the organic liquid is less than that of silica. Therefore, a delicato balance exists between gravitational and surface tension forces. Sowe organic liquids have densities greater than that of silica; however, those liquida are usually too expensive and therefore impractical to use.

A laboratory centrifugo has been used to effect this separation process, as shown in Figure 2.1. A 1 lurry consisting of water and a sixture of two minerals, galena and silica in this study, was introduced into the centrifuge through the feed inlet located in the aiddle of the centrifuge bowl. The heavy and hydrophobic galena particles reached the water/oil interface earlier than did the light and hydrophilic silica particles. Furthermore, the hydrophobic particles easily penetrated the organic liquid, while the hydrophilic gangue ninerals did not. Figure 2.2 shows an industrial-size centrifuge that can be slightly modified and used to offect the separation on a larger scale.

When both the desirable and undesirable particles are hydrophilic, such as scheelite/silica or magnetite/silica, the surface of the desired particles can be modified to be hydrophobic using a surfactant before the above technique is applied.

\subsection{EXPERIMENTAL OBSERVATIONS}

A slurry consisting of two minerals, a heavy and desirable mineral and a gangue mineral with a predetermined solid concentration, was placed initially in a reservoir tank. A surfactant was added into this tank, when desired. The slurry was then fod at a preset flow rate into a continuously running centrifuge at a given angular volocity ranging frow 18 to $390 \mathrm{rad} / \mathrm{s}(2 \mathrm{~g}$ to $640 \mathrm{~g}$ ). Heavy organic liquid can be introduced continuous ly near the centrifuge wall through an inlet tube, as indicated in Figure 2.1. However, in this study, a semi-continuous mode of operation was adopted, where a known aaount of a heavy organic liquid was placed inside the centrifuge and only slurry was introduced continuously. Salient properties of the heavy liquids chosen for the investigation are listed in Table 2.1.

Galena and silica particles of $400 / 500$ mesh (25 to 37 vierons) have been used as a model systen. An $x$-ray diffraction unit was used to analyze the aixture of minerals after the separation process was carried out. All the experiments vere conducted at $25 \mathrm{C}$ and at neutral pH. In those experinents, the effect of surfactant concentration, different organic liquids, angular velocity, amount of organic liquid, and flow rate of slurry on the netallurgical efficiency of upgrading of galena was investigated. Each is discussed in the following sections. 


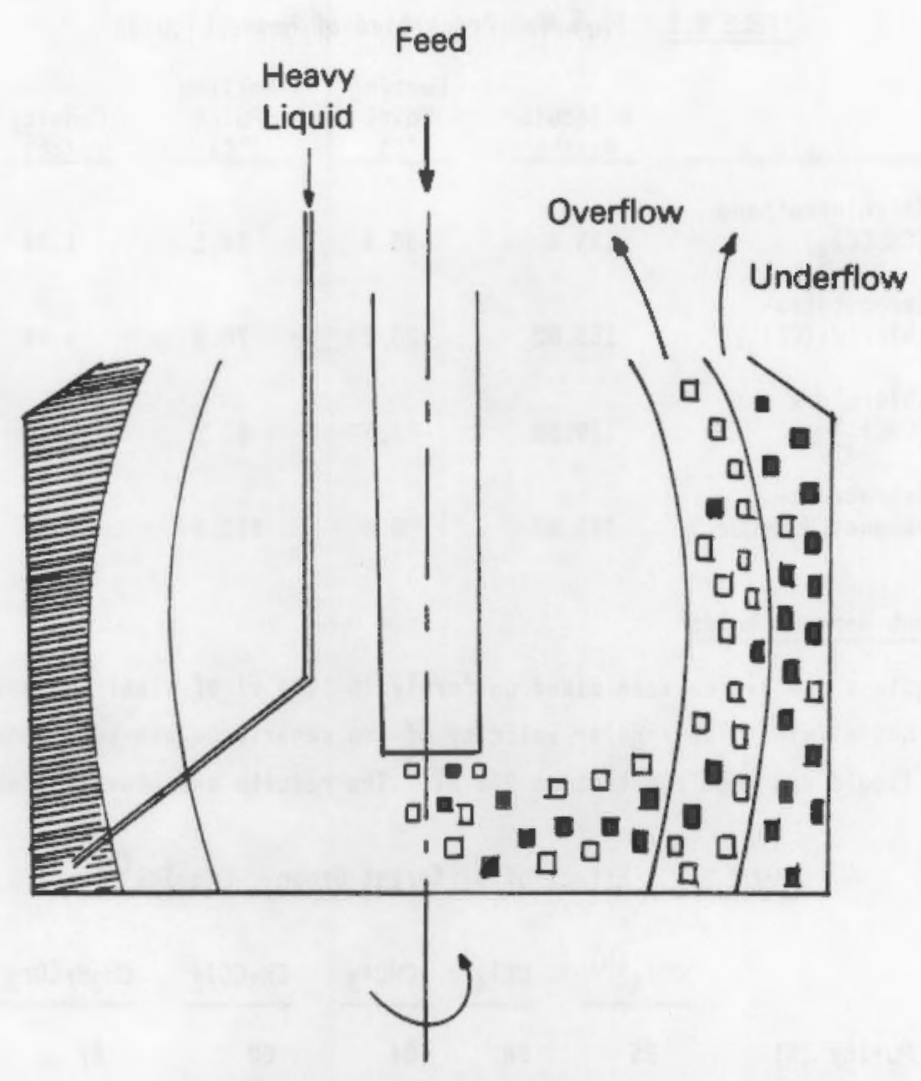

FICURE 2.1. Laboratory Centrifuge Basket

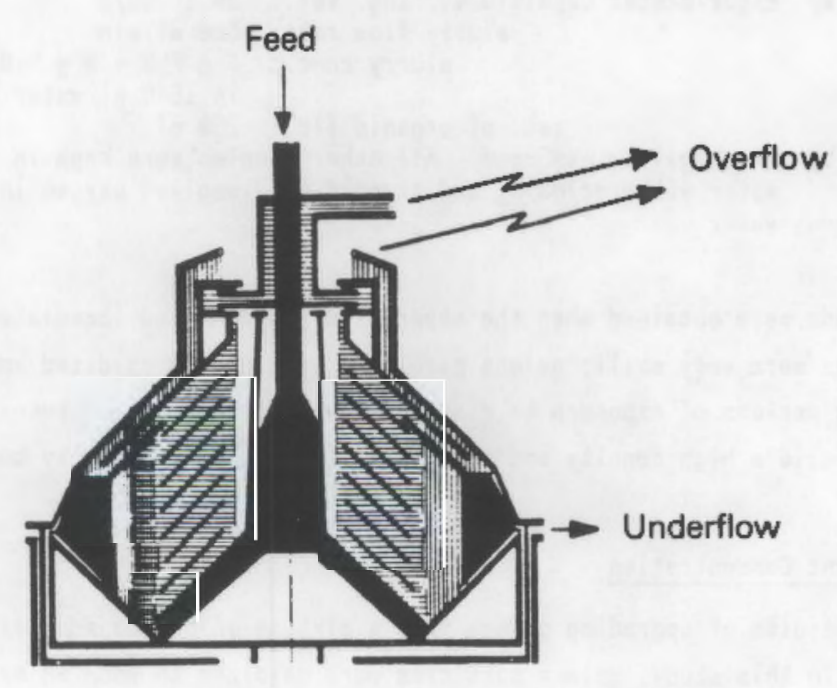

FIGURE 2.2. Industrial Centrifuge Basket 
TABLE 2.1. Physical Properties of Heavy Liquids

\begin{tabular}{|c|c|c|c|c|}
\hline Liquid & $\begin{array}{l}\text { Wolecular } \\
\text { Meight }\end{array}$ & $\begin{array}{l}\text { Weeting } \\
\text { Point } \\
\left({ }^{\circ} \mathrm{C}\right) \\
\end{array}$ & $\begin{array}{l}\text { Boiling } \\
\text { Point } \\
\text { (C) } \\
\end{array}$ & $\begin{array}{l}\text { Density } \\
(a / c c)\end{array}$ \\
\hline $\begin{array}{l}\text { Trichloroethane } \\
\left(\mathrm{CH}_{3} \mathrm{CCl}_{3}\right)\end{array}$ & 133.4 & -30.4 & 74.1 & 1.34 \\
\hline $\begin{array}{l}\text { Carbontetra- } \\
\text { chloride }\left(\mathrm{CCl}_{4}\right)\end{array}$ & 153.82 & -23.6 & 76.8 & 1.59 \\
\hline $\begin{array}{l}\text { Chloroform } \\
\left(\mathrm{CHCl}_{3}\right)\end{array}$ & 119.38 & -63.5 & 81.7 & 1.48 \\
\hline $\begin{array}{l}\text { Tetrabromo- } \\
\text { ethane }\left(\mathrm{CH}_{2} \mathrm{BrCBr}_{3}\right)\end{array}$ & 345.67 & 0.0 & 112.0 & 2.87 \\
\hline
\end{tabular}

\subsubsection{Effect of Different Heavy Liquids}

Five grams each of galena and silica were mixed uniformly in 1500 al of distilled water, and this slurry was introduced at a rate of $600 \mathrm{~m} / \mathrm{min}$. The angular velocity of the centrifuge was kept constant at $39 \mathrm{rad} / \mathrm{s}$. The amount of heavy organic liquid was kept constant at $250 \mathrm{al}$. The results are shown in Table 2.2.

TABLE 2.2. Effect of Different Organic Liquids ${ }^{(a)}$

\begin{tabular}{|c|c|c|c|c|c|}
\hline & $\mathrm{CCl}_{4}{ }^{(b)}$ & $\mathrm{CCl}_{4}$ & $\mathrm{CHCl}_{3}$ & $\mathrm{CH}_{3} \mathrm{CCl}_{3}$ & $\mathrm{CH}_{2} \mathrm{BrCBr} 3$ \\
\hline Purity (x) & 85 & 68 & 64 & 66 & 67 \\
\hline Recovery (x) & 90 & 98.4 & 99.1 & 95.6 & 30.5 \\
\hline
\end{tabular}

(a) Experinental Conditions: ang. vel.: $39.1 \mathrm{rad} / \mathrm{s}$ slurry flom rate: $600 \mathrm{al} / \mathrm{min}$ alurry conc.: $5 \mathrm{~g} \mathrm{PbS}+5 \mathrm{~g} \mathrm{SiO}_{2}$ ant. of organic liq.: $250 \mathrm{al}$

in 1500 al water

(b) Fresh galena was used. All other samples were kept in water after grinding and exposed to dissolved oxygen in water.

High recovery and grade were obtained when the separation was achieved immediately after grinding. However, because the particle sizes were very small, galena particles were easily oxidized and therefore obtained hydrophilicity after long periods of exposure to dissolved oxygen. Galena was recovered in tetrabromo-ethane because of the organic liquid's high density and an insufficient angular velocity to compensate far the liquid's excessive density.

\subsubsection{Effect of Surfactant Concentration}

Table 2.3 shows the results of upgrading galena from a mixture of galena and silica as a function of amyl xanthate concentration. In this study, galena particles were oxidized to such an extent that a surfactant had to be added to recover galena. The table shows that as the anount of anyl xanthate added increased, the metallurgical efficiency increased until the anount of the surfactant added exceeded $0.03 \mathrm{lb} /$ ton of slurry. 
TABLE 2.3. Eifect of Concentration of Aayl Xanthate (a)

Aayl Xanthate added (lb/ton of siurry)
Purity (x)
Recovery (x)

\subsubsection{Effect of Angular Velocity}

Tablo 2.4 shows the purity and recovery values of galena when two angular velocities of the centrifuge wore used. An expected, the higher the angular velocity reached, the greater the recovery becane. However, this occurred at the expense of the grade.

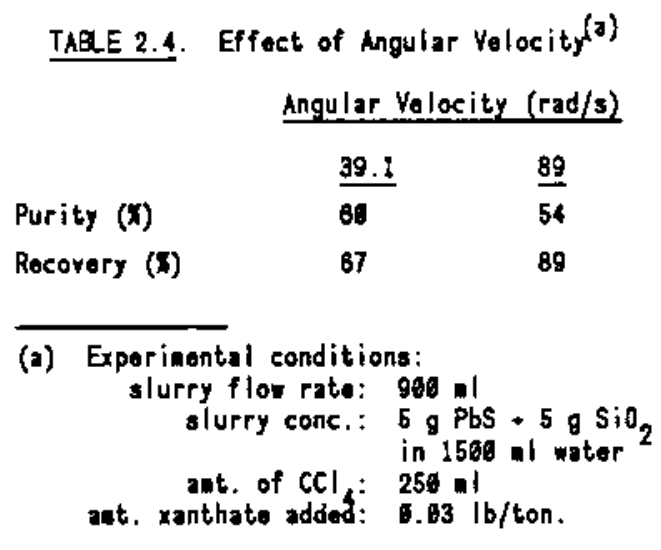

\subsubsection{Effect of Organic Liquid Added}

Table 2.5 shows the metallurgical efficiency of upgrading galena as a function of the amount of CCl, addod. As the tabte shows, there is an optiuun anount of the heavy organic that should be added. In generai, 250 al of $\mathrm{CCl}_{4}$ offers the best matallurgical efficiency.

TABLE 2.5. Effect of Organic Liquid Added (a)

\begin{tabular}{|c|c|c|c|c|c|c|c|c|}
\hline & \multicolumn{8}{|c|}{$\mathrm{CCl}_{4}$ added $(\mathrm{al})$} \\
\hline & 8 & $\underline{110}$ & $\$ 50$ & $\underline{180}$ & $\underline{228}$ & $\underline{250}$ & $\underline{290}$ & $\underline{326}$ \\
\hline Purity (x) & 52 & 54 & 88 & 65 & 67 & 88 & 61 & 51 \\
\hline Recovery $(x)$ & 99.5 & 94 & 97 & 96 & 98 & 98 & 84 & 72 \\
\hline
\end{tabular}

(a) Experimental conditions: ang. vel.: $39 \mathrm{rad} / \mathrm{s}$ slurry flion rate: $880 \mathrm{~m} / \mathrm{min}$ slurry conc.: $5 \mathrm{~g} \mathrm{PbS}+5 \mathrm{~g} \mathrm{SiO}_{2}$ in 1500 al wator ant. xanthate addod: $0.03 \mathrm{lb} / \mathrm{ton}$. 


\subsubsection{Effect of Flov Rate of Slurry}

The flow rate of elurry introduced into the centrifuge is also inportant to notallurgical officiency. Table 2.8 shows that one optinun flow rate offers the best result.

TAQEE 2.6. Effoct of Slurry Flow Rato(a)

\begin{tabular}{lccc} 
& \multicolumn{3}{c}{ Slurry Flow Rate $(-1 / m i n)$} \\
\cline { 2 - 4 } & $\frac{426}{86}$ & $\frac{600}{68}$ & $\frac{960}{60}$ \\
Purity (x) & 67 & 98 & 90
\end{tabular}

(a) Experinental conditions:

ang. rol.: $39 \mathrm{rad} / \mathrm{s}$

slurry conc.: $5 \mathrm{~g} \mathrm{PbS}+5 \mathrm{~g} \mathrm{SiO}$

ant. of $\mathrm{CCl}_{4}$ : 250 .

in 1500 of water 2

ant. of xanthats: $0.03 \mathrm{ib} / \mathrm{ton}$.

\subsubsection{Practical Application}

The results obtained in this study wore based on asal-ecale seni-batch tests. However, industrial centrifugas are available already in the arket to treat fine particle slurry on a larger scale. For exanple, basket-type centrifuges are manufactured by Centrico, Inc., cylindrical-conical boul contrifuges and disc contrifuges by $\theta i r d$ Uachine Company, Ine., and basket/scroll centrifuges by Tons Systens, Inc. Woat of these centrifuges aro ade to separate oil fron water, and, therofore, the spoed of rotation is nore than wat nay be required for the current investigation. However, with a littlo codification, these centrifuges can be used to treat these fine particles. A simple calculation indicates that the cost of treating $5 x$ slurry would be $84 /$ ton of 20 ids.

\subsection{FUTRE CONCEPT DEYEOPUENT}

Uineral industries are currently losing any eillion tons of desirable ninerals aach year siaply because of a lack of technology that can be used to treat fine particles. Wre than $20 x$ of tungsten ore slines all over the world, 505 of the tin ore ained in Bolivia, and substantial anounts of taconite ore in the United States are discarded because of a lack of technology.

This study has deanstrated that finely divided heary and hydrophobic particles can be separated by centrifuga force in a two insiscible liquid systes. Further investigations should be carried out on two oxide syateas such as scheelite/silica, cossiterite/silica, and iron oxide/silica.

In these eystems, because both minerals are originally hydrophilic, a surfactant must be added to ake the desirable mineral hydrophobic. For exanple, hydroxanate or sodiun oleate are good examples of such surfactants for these ninerals. Further studies pursuing these concepts should be conducted.

A careful study on solid-liquid separation after the separation process should be conducted to make an overall assesseent of the process. Wo conducted a prolicinary investigation on the separation of ainerals fron the organic phase and found that more than 9EX of organic liquid can be recovered and roused without distillation. Further investigation along this line should be carried out.

\subsection{LITERATURE SURVEY}

No literature information is available rolating directly to the concept used in this study. However, the fluid behavior in a centrifuge has been well docunented (Coulson and Richardson 1978; Hau 1981; Svarovaky 1977). Many investigations have concerned separation of eineral particles using two inaiscible liquids. Prudich and 
Henry (1978) have attempted to separate coal particles fron gangue ninerals by an oil/water syston. Other investigators have developed force balances between gravity and surface tonsion on particles placed in liquid (Uaru, Wasan and Kintner 1971; Yinitzer 1973; Huh and uson; Rapachietta and Neumann 1977). Qthers have attempted to separate particlos by liquid-liquid contacting (Albertason 1971; Raghavan and Fuerstenau 1875).

The literature survey reveals a need to devolop a fundanental approach to particlo behavior in two inmiscible liquid aystems under the influence of centrifugal force.

\subsection{REFERENCES}

Albertseson, P. A. 1971. Partition of Cell Particles and yacromolecules. 2nd Edition, Viley-Int., Nev York.

Coutuon, J. M., and J. F. Richardson. 1978. Chenical Engineering, Yol. II, Porganon Press, Mes York.

Hsu, H. 1. 1881. Separation by Centrifugal Phenomena. John Tiley \ Sons, Ner York.

Huh, C., and S. G. Mason. 1974. J. Coll. Int. Sei. 47(2):271.

Maru, H. C., D. T. Wasan and R. C. Xintnor. 1971. Ches. Eng. Sci. 28:1615.

Prydich, U. E., and J. D. Honry, Jr. 1878. AlChE. 24:788.

Raghaven, S., and D. I. Fuerstenav, 1875. AIChE Sye. Ser. 150(71):58.

Rapachietta, A. Y., and A. T. Neunann. 1977. J. Coll. Int. Sci. 58(3):555.

Svarovsky, L. 1977. Solid-Liquid Separation. Buttorworths, London.

Vinitzer, S. 1973. Separation Sci, B(1):45. 


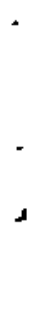


BIOTECHNOLDGY SEPAMTIONS 


\author{
S. K. Kawatra and T. C. Eiselo \\ Department of Wotallurgical Engineering \\ S. T. Bagley \\ Biology Department \\ Michigan Tochnological University
}

\title{
ABSTRACT
}

The use of aicroorganises, particularly lithotrophic bacteria such as Thiobacillus (T.) ferrooxidans, was investigated as a cost-offective method for recovering coal that is currently discarded as being too dirty to burn. The bacteria are used to modify the surfaces of the pyrite particlea contained in the sulfur. By altering the surface of the pyrite, it can be separated fros the coal by the froth flotation process, a separation that mould not be possible without pretreatwent.

Experiments were conducted using two straina of lithotrophic bacteria, throe species of nonfithotrophic bacteria, and one species of yezst. Results indicate that, while all eicroorganisns showed considerable ability to alter the pyrite surface and thus prevent flotation, the most offective was one of the strains of T. ferrooxidans, wich produced nearly complote suppression. The tests also deterained that the suppression is caused by direct celfuiar attachaent and the action of intracellular enzynes, not by extracellular enzynes released into solution.

\subsection{INTRODUCTION}

In nost coal nines, 265 or nore of the mined coal consists of material that is finer than 6.5 ailliceters and contains large anounts of ash and sulfur. Bacause of the difficulty of cleaning this fine coal, it is frequently discarded. Therefore, nuch of the heating value of the coal is lost because of a lack of a sufficiently of fective cleaning technique.

Bacteria and other aicroorganisas provide a pronising way to improve the officiency of processing coal and other ainerals. Because bacteria apply biotic onergy in materials cycling, replacing fuel, eicroorganises can be considered as the equivalent of energy (Decker 1895). Also, using bacteria can provide opportunities for reducing capital and labor costs. Applying bacterial techniques to fine coal processing could not only save energy, but could also inprove cleaning efficiency enough to allow coals currently considered to be too dirty to burn to be recovered and used.

Bacteria have long been known to be ablo to leach inpurities stch as pyrite from coal, thus reducing tho sulfur content. However, no coal preparation plants use bacteria in their processes, fargely because of two factors; 1) pyrite leaching by bacterially catalyzed dissolution is fairly slow, and 2) pyrite leaching processos do not reduce the coal ash content. Therefore, an unconventional application of bacteria in aineral processing is needed.

\subsection{CONCEPT ASSESSINENT}

In the following sections, the concept is described, and its potential onergy savings, technical feasibility, and status are discussed.

\subsubsection{Concept Description}

The proposed concept uses bacteria and bacterial enzyes to alter the surface of the pyrite particles in coal. This surface alteration occurs very rapidly and allows the coal to be recoved from the pyrite by froth 
flotation. If the pyrite surface is not altered, the performance of froth flotation in reacing pyrite, and therefore in reducing sulfur, is poor.

Froth flotation is based on the preferential attachment of air bubbles to surfaces that are hydrophobic, or have los affinity for water. Then air is dispersed in a eixture of finely ground ainerals in wator, the hydrophobic particles attach to the air bubbles and are carried to the surface, leaving the hydrophilic, or waterloving, einorals behind. Various reagente are added to adjust the surface cheaistry of the einaral particlas and to alter the properties of the einaral-laden froth on the surface, therefora affecting the perforance of the process. This technique is particularly suitable for coal because coal surfeces are naturally hydrophobic, thereas eost of the asoceiated ainerals are hydrophilic (Aplan 1878).

The major drasback to using froth flotation for cleaning fine cosl particles is that, unlike other ainerals in coal, pyrite is naturally hydrophobic. Pyrite is therefore floated along with the coal, increasing the sulfur content of the froth product. This probles increases as the pyrite particles becone sealler because the pyrito's density is not able to keop the pyrito froc floating. The only solution is to solectively alter the surface of the pyrite particles froe hydrophobic to hydrophilic, thuo preventing their flotation, but vithout adversely affecting the hydrophobicity of the coal.

Lithotrophic ("rock-eating") bactoria such as T. ferrooxidans vill catalyze the oxidation of pyrito to a soluble forn. Thile complete dissolution of the pyrite requires several woka, the bactoria attach to and alter the pyrito surface in a mattor of einutes. This alteration wa predicted to change the pyrito surface from hydrophobic to hydrophilic, thus allowing the froth flotation process to float the cosl any froe the pyrite.

Experinents wre conducted at Michigen Technological University (NTV) to test the ability of bactoris to reduce the tendency of pyrite to float. The resulte are shom in Table 3.1 . In the experiente, pure pyrite at $\mathrm{pH}=2 \mathrm{~ms}$ used. In addition to two atrains of $\mathrm{T}$. forrooxidans, three other species of unrelated bacteris (Pseudomoanas fluorescens, Klebsielle terrigena, and Lactobecillus acidophilus), and one apecies of yeast (Saccharonyces cerevisciae) were used. In the table, the lowed values of the percentage of pyrite flosting indicate that the efficiency of the pyrite depression has increased.

The experiments at uTU showed that, whilo live cultures of $T$. forrooxidans are nost effoctive for deprossing the flotation of pyrite, other becteria also exhibit the ability to reduce (depreas) pyrite flotation, even if the bacteria have ne specific capability to dissolve pyrite. The depression is therefore at least partly the result of the pyrite particles beconing coated by eicrobial protoins. In addition to the goneric action, T. ferrooxidans specifically attach to and oxidize the pyrite aurface, thus producing a nore effective depression

TAQE 3.1. Rosults of Bactorial Dopression Tosts Conducted at ITU

Nicroorganisa Used

Controls, Ho nicroorganisns

T. ferrooxidans

T. forrooxidana, strain PA1

Pseudonoanas fluorescens

Klobaialla torrigena

Lactobacillus acidophilus

Saccharonyces cererisciae
Porcentago of Pyrito Floating (oan value for all tests)

$21.8 \pm 2.1 \times$

$6.78 \pm 0.07 x$

$2.48 \pm 0.068$

$5.4 \pm 1.5 x$

$4.5 \pm 0.28$

$7.6 \pm 0.5 \%$

$2.6 \pm 0.35$ 
of the pyrite. The pyrite is oxidized by intracellular onzymes that are not released into the suspending nediz, so vither whole bacteria or bacterial extracts are needed for this process.

The proposed process would be conducted in throe stages using a bacterial culture tank, a conditioner, and a froth flotation bank. Bacteria would be cultured in the culture tank, using high-sulfur coal tailings and aall quantities of trace ainerals as bacterial nutrients. The cultured bacteria rould then be added to the conditioning tank, along with the coal to be processed, and wixed for a short period to allow the bacteria to conplotely attach to the pyrite. The pyrite and ash minerals would then be removed in the froth flotation staga, leaving a clean, low-ash, fine coal product that could be burned to produce power with winimal emission control.

The optinum conditions for the coal flotation solution, such as pH and reagent dosage, vary greatly for coals obtained frow various seans. In many cases, the solution conditions will not allow living eultures of T. forrooxidans to be used because they vill be rapidly killed by high pH values. In those cases, two options aro available. Either the relevant enzynes can be extracted fron the bacterial culture and added to the conditioner in the absence of living colls, or a culture of bacteria that can tolerate the solution conditions can be used. Thesa modifications ill allor the process to be applied to nearly all coals that can be aade to eeet sulfur standards by the renoval of pyritic sulfur.

\subsubsection{Potential Egergy Sarings}

The bacterially enhanced flotation process vill recover the heating value that would othersice be fost, vithout adversely affecting the onvironsent. With little additional expenditure of processing energy and capital, delivered heating value of the aine product can be increased by $20 x$. Overall environaental iupact may actially be teduced because leas coal would have to be eined if $20 x$ were not diacarded.

Unlike many other processes for coal desulfurization, the proposed process does not use expensive or dangerous chesicals, and the waste is in a solid forn that can easily be disposed of. The largest nonconventional requiresent is the bacterial culture tank. However, the foed for this culture tank can be supplied fron by-products of the cleaning plant; therefore, the tank is quite inexpensive to operato.

\subsubsection{Tectinical Feasibility}

Experiments conducted to date have used pyrite mined fron pure deposita of the aineral, Using that type of pyrito, bacteris are very effective for suppressing flotation. However, the pyrite actually contained in coal appears to have different surface propertiea because of its formation and long residence in the presence of complex organic alecules. Flotation of coal pyrite is therefore nore difficult to prevent than is flotation of pure aineral pyrite. Further work is needed to inprove the effectiveness of depressing coal pyrito by bacteria. The of factiveness can be inproved by adjusting the treatment tige and solution conditions.

The bacterially onhanced flotation process may be usoful for all coals that are currently too high in pyritic sulfur to meet EPA standards. For exanplo, in some cases coats that currently aro suitablo only for power generation may be sufficiently upgraded for use as higher-value netallurgical coal. Also, this process could be used in sall portable plants to process coal wasto dumps and therefore recover usable coal without the expense and high energy consurption of mining.

Coals containing substantial anounts of organic sulfur ill also be iaproved by this process but ill bo primarily suitable as 'blend products' that can be used with low-sulfur coals, or to reasov part of the load from power plant stack-gas scrubbers. Coals that are very high in organic sulfur (3x) cannot be sufficiently desulfurized by any known, econonically practical process. Coals lacking natural hydrophobicity cannot be treated by the proposed process.

A process rolated to the propesed concept could be applied to the leaching of precious eetals fron refractory ores. Precious metals often occur as finely divided particles dispersed in a pyrite-rich matrix. To treat these ores by cyanide leaching, the rock wust be ground until the procious metal inclusions are oxposed to the cyanide 
solution. This requires trenendous amounts of onergy because grinding is a very inefficient process. However, if T. ferrooxidans were used to lightly leach the pyrite atrix, the porosity of the rock rould increase sufficiently to wake extensive grinding unnecessary. A great deal of energy would be saved because bactorial leaching is a spontaneous process that does not require any external onergy inputs. Bacterial protreateont is potentially of great use to the precious notals industry as wll.

\subsubsection{State-of-the-Art}

Several physical and cheaical techniques have been investigated for cleaning and desulfurizing coal wastes. However, the physical separation of coal and pyrite usually is not sufficiently solective at fine sizes, and cheaical techniques tand to be expensive and often produce toxic wasto produets that are difficult to dispose of. lost interest has concentrated on developing physical soparations rith inproved selectivity because such processes have low onough costs to be useful (Kawatra and Eisolo 1997).

Because puroly physical separations appear to be approaching thoir ultimate liuits for renoving sulfur from coal, other technology is needed to achieve further inprovenents. Biological processing, thich possesses any of the advantages of chenical processing at less expense, is a prouising mothod for achieving these improvements (Kayatra, Eisele and Bagley 1987).

The nost videly investigated application of bacteris to wineral processing is as catalyste for leaching operations. The bactoris increase the rate of diseolution processes, wich norally occur very slowly, such as oxidizing and diseolving pyrito in acid solutions. Pyrito dissolution ia accolerated soveral hundred-fold by the action of bacteria such as $I$. forrooxidans and Sulfolobus (S.) acidocaldarius (Ehrlich 1988). Theso bacteria have therefore been axtensively investigated for lesehing pyritic sulfur from coal. Hovever, conplobs leaching of pyrite by I. ferrooxidans sypically requires soveral moks (Hoffmann ot al. 1981), and the high-teaperature organise S. acidocaldarius, thile more rapid, atill roquires processing times of about one week (Kargi and Robinson 1985).

The large capital investment required for a leaching tank of sufficient volune makes cosl desulfurization by bacterial loaching ispractical at current coal prices. Fork conducted at wT has shown that intense aeration shortens the neceesary ieaching tine by soveral days, but the process is still too slor to bo econouical.

Keapton ot al. (1980) discovered that conditioning very high sulfur coals vith T. ferrooxidans improved the ability of oil aggloneration to remove pyrite fron the coal. Unfortunatsly, oil aggloneration is not a particularly econonical process because of the cost of the large anounts of oil used. However, the phenomena responsible for the perfornance of oil agglomeration are ainilar to those involved in froth flotation, so the bacterial pretreatsent that as successful for oil agoloneration iv equaliy applicable to froth flotation (Attia and Elzeky 1985; Dogan et al. 1985). The major barrier to applying this procesa rowaine the peculiar characteristics of cosl pyrite relative to pure aineral pyrite, which akes depression of the coal pyrite in flotation more difficult than vould bo expected.

Yarious chenicals have beon found in the past to depress the flotation of pyrite (Baker and Niller 1971). Howaver, these chomicals also depress the flatation of cosl to some extent, which is not true for bacterial pyrite depression, and are no more effective for depressing pyrite than is the bacterial nethod. The bactorialiy assisted process therefore is superior to existing techniques.

\subsection{FUTURE COMCEPT DEVEOPNENT}

The nost inediate step required to further develop the concept is to inprove the offectiveness of bacterial depression of coal pyrita. Inproving the of fectivenese ill involve using a oodified conditioning technique, consisting of vigorous, forced aeration at high bactaria and solids concentrations. Also, the salts in solution -ill be adjusted to the optinue concentrations deternined in earlior leaching oxperinonta. Using this nodified 
conditioning tochnique rill allow the pyrite to be nore strongly depressed in the froth flotation stage. This also -ill proferentialiy dissolve the extrenely fine pyrite inclusions that are difficult to physically separate from coal. Further work is also needed to develop bacterial pretreateent of refractory precious eetal ores to reduce grinding costs.

After the laboratory test work has been conpleted, a sall pilot circuit that uses bacterially assistod flotation rill be designed and constructed. Samples of fine coal currently being discarded froe various plants because of high sulfur content will be collected, and the pilat circuit's capability to treat these coals rill be deterained. Then the pilot teats have been conpleted, arrangenents will be made with a coal cleaning operation to treat oither a coal waste dump or a plant waste strean using the pilot circuit, as a final test of the concept.

\subsection{REEBREME}

Aplan, F. S. 1970. "Coal Flotation." Flotation. 2:1235-1264. od. L. C. Fuerstenau, Maerican Institute of Uining, Lotallurgical, and Petroleun Eggineers, Mon York.

Attia, Y. A., and U. A. Elzeky. 1985. 'Biosurfoce Lodification in the Soparation of Pyrite fron Coal by Froth Flotation. Processing and Utilization of High Sulfur Coala. ed. Yo. A. Attia, El sovier, Aasterdas, The Notherlands.

Baker, A. F., and K. J. Millar. 1971. Hydrolyzed Hatal Iona as Pyrite Depressenta in Coal Flotation: A Laboratory Study.' Report of Investigation 7518, U.S. Bureau of Wines, Departeent of Interior, Washington, D.C.

Decker, R. F. 1985. 'Biotechnology/Haterials: The Growing Interface.' Marican Society for Hatals, Edrard Dellille Canpbell Lecture, Vichigan Technological University, Houghton, Michigan.

Dogan, y. Z., et al. 1985. "Bacterial Leaching Yersus Bacterial Conditioning and Flotation in Desulfurization of Coal. In Proceedings of the 15th International Uineral Processing Congress, Yol. 2, pp. 304-313, Cannes, France.

Ehrlich, H. L. 1988. What Types of Uicroorganisna are Effoctive in Bioleaching, Bioaccunulation of Lotals, Ore Beneficiztion, and Dosulfurization of Fossil Fuals." In Biotechnology and Bioengineering Symposium No. 16, pp. 227-237. John Niloy Sons, Nor York.

Hoffaan, U. R., ot al. 1981. 'Kinotics of the Resoval of Iron Pyrite fron Coal by Vicrobial Catalysis." Applied and Envi ronmental Uicrobiology. 42:259-271.

Kargi, F., and J. M. Robinson. 1985. 'Biological Ronoval of Pyritic Sulfur fron Coal by the Thernophilic Organism, Sulfolobus Acidocaldarius." Biotechnology and Bioengineering. 27:41-49.

Kawatra, S. K. and Eisele, T. C. 1987. "Coluan Flotation.' In Fine Coal Processing, ed. R. R. KIitupel, Noyes, Park Ridgo, Nev Jersey.

Karatra, S. K., T. C. Eisole and S. T. Bagley. Noveuber 1987. "Coal Desulfurization by Bacteria." Uinerals and vetal lurgical Processing. pp. 189-192.

Keapton, A. O., et al. 19ad. Removal of Pyrite fron Coai by Conditioning ith Thiobacillus ferrooxidans Fol lowed by Oil Aggloneration." Hydronetallurgy. 5:117-125.

\subsection{BIBLIOGRAPHY}

Beier, E. 1985. "Renoval of Pyrito from Coal Using Bacteria." In Processing and Utilization of High Sulfur Coals, pp. 643-672. Coal Science and Technology F, Elsevier, Msterdan, The Netherlands.

Brock, T. D. 1978. Thernophilic Microorganisns and Life at High Tomperatures. Springer Yorlag, Now York.

Capes, C. E., at al. Novenber 1973. 'Bacterial Oxidation in Upgrading Pyritic Coals.' CIU Bulletin, pp. $88-91$.

Dugan, P. R. 1988. "Wicrobiological Desulfurization of Coal and Its Increased Monotary Value." In Biotechnology and Bioengineoring Symposium No. 16, pp. 185-293. Sohn Viley \& Sons, Nov York. 
Isbister, J. D., and E. A. Kobylinski. 1985. Mierobial and Desulfurization of Coal.' In Processing and Utilization of High-Sulfur Coals, pp. 627-841. Coal Science and Technology fo, Elsevier, Nisterdan, The Natherlands.

Kargi, F., and J. H. Robinson. 1986. 'Renoval of Drganic Sulphur fron Bituninous Coal." Fuel. 65:397-399.

Honticello, D. J., and R. R. Finnerty. 1985. Uierobial Desulfurization of Fossil Fuels. Annual Reviens of Microbiology. 39:371-389.

Wurphy, J., ot al. 1985. "Coal Desulfurization by Vicrobizl Processing." In Processing and Utilization of High-Sulfur Coals, pp. 843-652. Coal Science and Tochnology \$8, Elsovier, Mesterdan, The Netherlands.

Mational Uaterials Advisory Board. 1981. 'Comeinution and Energy Consumption.' Publication Nuab-384, National Acadeny Press, Washington, D.C.

Norris, P. R., L. Parrott and R. M. Warsh. 1988. "Loderately Thernophilie Mineral-oxidizing Bactoria.' In Biotechnology and Bioengineering Symposiun No. 18, pp. 253-282. John Wi loy L Sons, Ner York.

Silverman, U. P. 1987. 'bechanisn of Bacterial Pyrito Dxidation." Journal of Bactoriology. 94:1646-1051.

Singer, P. L., and 1. Stuan. 1976. 'Acidic Uine Drainage: The Rato Detoraining Stop.' Seience. 187:1121.

Vaseen, Y. A. 1985. 'Conercial Vicrobial Desulfurization of Coal.' In Processing and Utilization of High-Sulfur Coals, pp. 699-715. Coal Seience and Technology f8, Elsovier, Amstordan, The Notherlands.

Yang, D. C. 1984. IStatic Tube Flotation for Fine Coal Cleaning. In Bth International Symposiue on Coal Slurry Conbustion and Technology, Pp. 582-597. Pittaburgh Enorgy Tochnology Conter, Pittsburgh, Pennsylyania. 
4.6 PERIDDIC, CROSS-FLOW SEPARATION OF LARGE MOLECUES, ESPECINWY PROTEINS, ACCDRDING TO THEIR DIFFUSION CDEFICIENTS
1. B. Baratuci
L. J. Cornotl
R. J. Adler

Departnent of Chenical Engineering Case Vestorn Reserve Univeraity

\section{AESTRACT}

A method is being developed for separating relatively large nolecules that have different diffusion coefficients. The molecules, in solution in their natural solvent onvironment, are separated by tro mutually perpendicular coordinated flows, both periodic and bi-directional. The molecules are subjected to only gentlo shear. Wore rapidly diffusing species concentrate at one ond of a separator tube, white nore stouly diffusing species concentrate at the other end. The cut point is continuously adjustable vithout requiring hardware changes, as is the tradeoff betwen sharpness of separation and production rate. Sharp separations of noleculos having slightly different diffusion coefficients are possible. The new wothod can be viewed as a combination of field flow fractionation and paranotric pumping.

The nem concept is potentially attractive for separating aixtures of delicate biochenicals, and hazardous or expensive inorganics. The anticipated rapid gronth of pharmaceutical proteins produced by recombinant oNh technology provides a prite potential morket. Other possible warkets are flavors and fragrances, and expensive or hazardous inorganics such as those found in nuelear fuel reprocessing.

A mathenatical model was developed and used to predict the perforance of the anthod on a binary mixture of proteins in aqueous solution. The proteins are assumed to have molecular diffusion coefficients of $0.9 \times 10^{-7}$ and $1.6 \times 10^{-7} \mathrm{~cm}^{2} / \mathrm{s}$. Separation is ealeulated to occur in : hour with recoverios and purities oxceeding 99x. Calculations indicate that higher recoveries and purities asy be readily achieved with soneshat more processing tino; for example, 99.3X recovery and purity would requice 2 hours of processing tias. The feed protain concentration is approximatoly $0.4 \times$. and the rate of processing is about 1 gram of protein per liter of separator tube volune per hour.

The next logical steps in developing this concept are to use the mathenatical model to explore a wide range of operating conditions. Also, the new process should be discussed with pharnaceutical and possibly other conpanies and with equipment manufacturers. If these contacts are encouraging, the aethod should be explored further with laboratory-scale proof-of-prineiple experiaents and then production-scale experiments.

\subsection{CONCETT ASSESSMENT}

This section includes a description of the concept, and diseussions of the concept's potential energy savings, technical forsibility, and present status.

\subsubsection{Description of the Concept}

This concept involves a mothod for separating large wolecules vith different diffusion coefficients. The separation is eaused by the coordination of two types of eutually porpendicular, coordinatod periodic floss that are bi-directional. A periodic cross-flow produces short-range, tine-varying partial separationa, and a periodic axial flow astiplies and converts the short-range separations into useful separations in the axial direction.

The molecules, in solution in a low molecular wight solvent, are processed in a tube of rectangular cross section. Two parallel walls consist of neabranes that are permeable to the solvent but not to the nolecules being separated. The other two walls are completely impermeable, and the ends of the tubes are alternately inlets and outlets for axial flow. 
The method is inherently very flexible. The number of separation stages rithin a single tube can be yaried from a for to any hundreds without hardware nodifications; the change is ade sinply by varying user-controlfed operating parameters. Both batch and continuous operation are foasible. The nolecules that diffuse nore slowly are concentrated and renoved fron one end of the tube, while the eolecules that diffuse core rapidly are concentrated and removed at the other end of the tube. Alternatively, the nethod can be operated in a chronatographic node where nolecules energe at one end of the tube sequentially in the order of their molecular diffusion coefficient values.

The concept can be viered as a suecessful conbination of fiold flor fractionation (Giddinge ot al. 1986; Janca 1988) and paranetric punping (Tilhele ot al. 1988). Wany of the best features of those processes are captured, and the less desirable features are avoided.

Holecules are procesesed in their natural solvent environments and are subjected only to very gentle shear. The delicate cheaicals and biochesicals should not be harned. The process aay be espocially holpful for such types of molecules as proteins, enzynes, nacronoleculos, flayors, fragrances, and costly or environmentally hazardous inorganics. Wo temperature, $\mathrm{pH}_{1}$ ionic strength, or other intensive variable changes are required in this separation procese (except nodest preasure variationa for driving the flows). Taste streans are not generated because no reagents or separating agents are added.

Figures 4.1 and 4.2 heip explain the concept. Figure 4.1 shows the hardwere used and Figure 4.2 explains a batch separation sequence. Each is discuesed in moro detail in the following subsections, followed by general discussions of the proposed process operated in continuous and chronatographic nodes.

\section{Schenatic of Hardware}

Figure 4.1 is a schenatic of a laboratory batch version; the center section, dram with thick lines, comprises the soparator tube and associated chabbers, all of rectangular cross section. The two horizontal dashed lines represent nenbrane sheets that fore two parallel walls of the separator tube 2 . These nesbranes are perpendicular to the plane of the drasing. The other two wals of the tube (parallel to the plane of the draving) are inperneable. The ends of the tube adjacent to $A$ and $a$ are open and permit inflor and outflor.

The separator tube 2 is long and thin. Its dieensions are typically a fos centimeters in the $A, B$ direction; wuch less than 1 mo in the C, D direction; and a for centiesters in the direction perpendicular to the plane of the fraving. Auxiliary chabers 1 and 3 are adjacent to the eain separator tube.

The auxiliary equipeent surrounding the separator tube and associated chanbers consists of four syringes $A, B, C, D ;$ suall-bore connecting tubing (not labeled); and on-off valves $a, b, c, \ldots, p$ for connecting the syringes to different parts of the separator tube 2 and associated chanbers 1 and 3 . Syringes $A$ and $B$ can produce axial $f$ lov of solution through the separator tube, wile ayringes $C$ and $D$ allow the cross-flor of solvent through the aenbrane malls.

\section{Sequence of Operations Comprising a Cycle}

Figure 4.2 focuses on the separator tube 2 of Figure 4.1 and showa a sequence of six steps conprising a cycte that is repeated indefiniteiy to bring about the separation. For elarity, a bateh separation of two species in solution is described; ganaralizations are discussed later. Each of the six lines in figure 4.2 shows the action taken during a stop and the state resulting from the action, i.o., the state resulting at the ond of the step.

The separator tube 2 is filled initially with a solution of uniforn conposition containing two species, $F$ and $S$. For this example, $F$ will be the faster diffusing species, and $S$ the lover diffusing species. The steps to be described concentrate $F$ at the end of the tube adjacent to $A$ and sinultaneously concentrate $S$ at the end of the tube adjacent to $\theta$. 


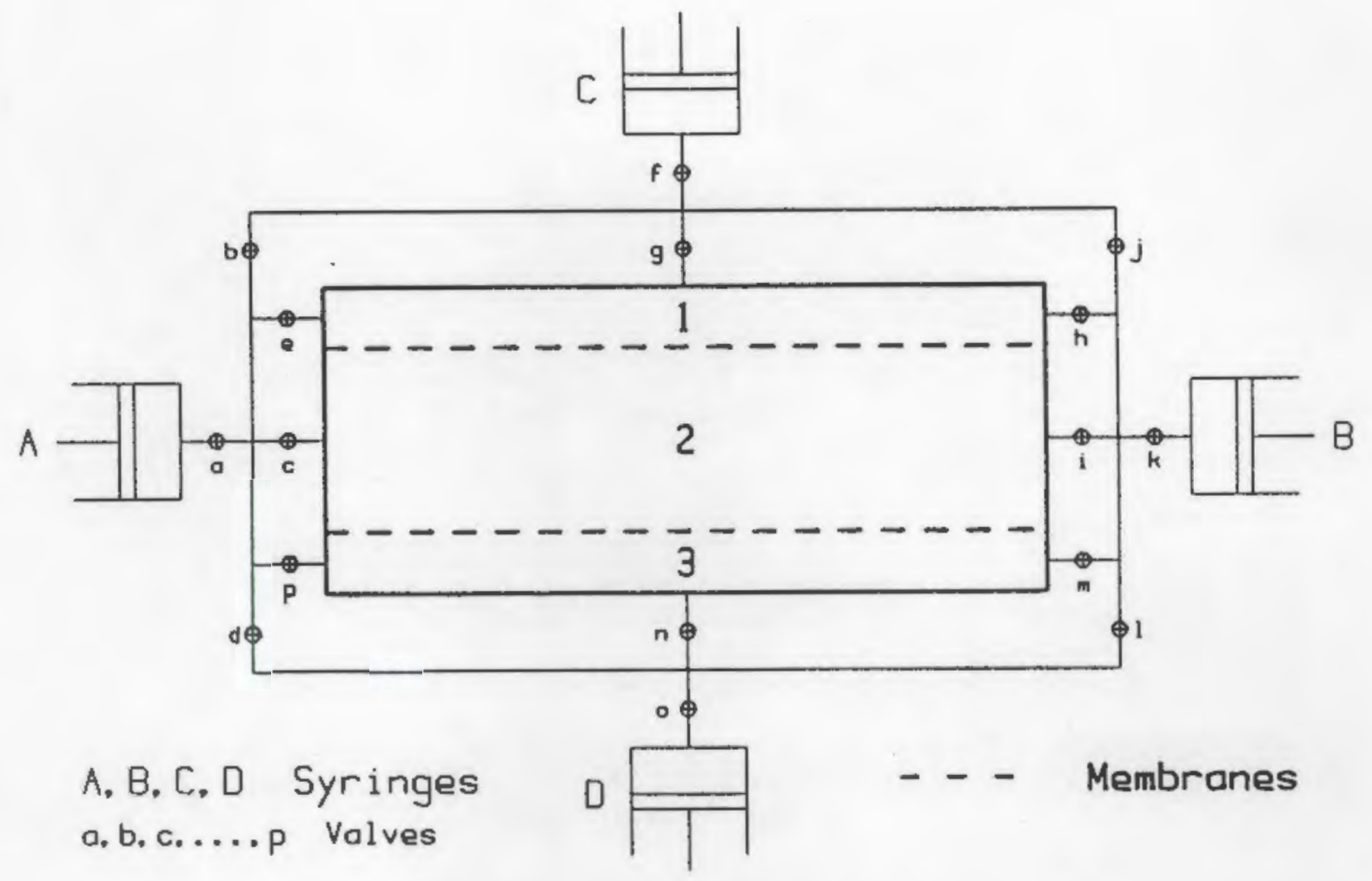

FIGURE 4.1. Schematic of the Concept

Step 1 involves a cross-flow of solvent inte separator tube 2 through the upper menbrane, across the tube, and out through the lower membrane. This cross-flow of solvent originates from syringe $C$ and flows through valves $f$ and $g$ into auxiliary chanber 1 . It then flows through the upper menbrane, across separator tube 2 , through the lower nembrane, into auxiliary chamber 3 , through valves $n$ and 0 , and into syringe 0 . The cross-flow convects $F$ and $S$ nolecules in the separator tube to the inner surface of the lower nembrane mill, eatabliahing a thin superiapesed layer of concentrated $F$ and $S$ molecules innediately adjacent to the menbrane.

Step 2 involves an immediate and rapid flow of pure fluid toward $B$. The $F$ and $S$ molecules do not nove appreciably because they are still positioned in a thin boundary layer adjacent to the lower menbrane. The average distance the fluid is noved, $x_{2}$, is selected to achieve a zero net flow of fluid over the cycle.

Step 3 is a quiescent period during which no flow occurs. The duration of step 3 is selected to allow the concentration polarization of both species established during step 1 and remaining at the end of step 2 to relax partially by molecular diffusion perpendicular to the membrane wall. At the end of step 3 , the nolecules are in two partially superimposed layers, one containing $F$ and the other containing $S$ molecules. The $F$ layer is thicker than the $S$ layer; that is, the $F$ layer extends farther fron the membrane surface into the tube than the $S$ layer because the diffusion coefficient for $F$ is greater than it is for $S$. If the initial concentration polarization layer is nuch thinner than the thickness of the separator tube, then the diffused layer thicknesses are proportional to the square roots of their respective molecular diffusivities. If the initial layer thicknesses are appreciable, a more complicated analytical relationship exists.

In step 4, a fast but laninar axial flow in the direction of $B$ to $A$ displaces a small fraction of the fluid in the tube in a relatively short time before additional molecular diffusion occurs. Because the axial flow is laninar, it typically moves the $F$ nolecules farther than the $S$ aolecules since the $F$ molecules typically extend farther into the tube cross-section than do the $S$ molecules. Lot $x_{4}$ be the average axial displacenent of the 


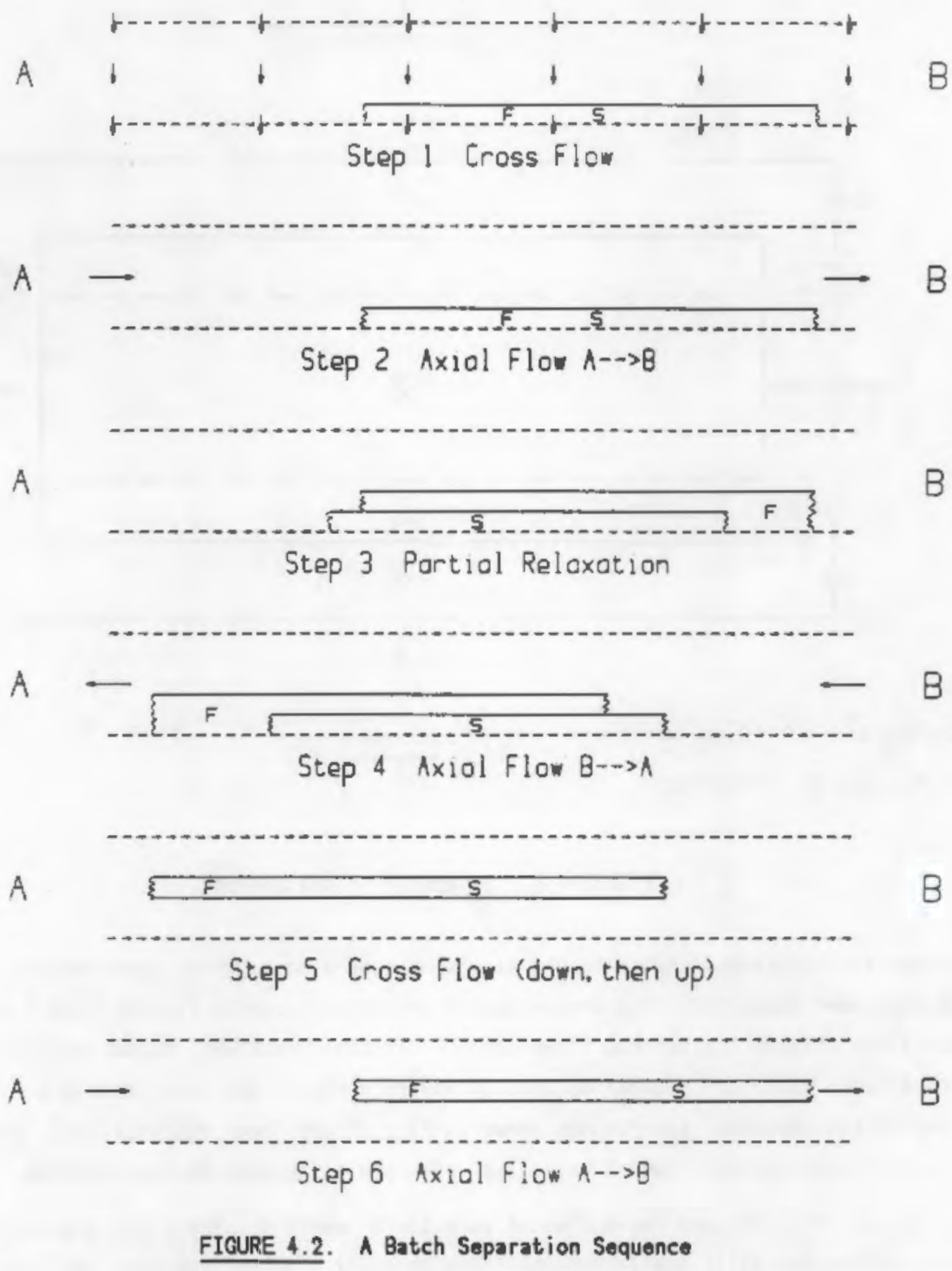

fluid, $x_{4 F}$ be the average axial displacenent of the $F$ nolecules, and $x_{4 S}$ be the average axial diaplacement of the $S$ molecules. All of these displacements are negative because the flow is toward $A$. Fron the above considerations, $x_{4}<x_{4 F}<x_{4 S}$. The second of these inequalities, $x_{4 F}<x_{45}$, represents sone separation in the axial direction. The separation distance $\left|x_{4 F}-x_{45}\right|$ in the axial direction is proportional to the fluid displaceaent $x_{4}$.

Step 5 conaists of a fast downward cross-flow to re-establish the concentration polarization present at the end of steps 1 and 2 . This downward cross-flow is followed by fast upward cross-flow to convect the layer of concentrated $F$ and $S$ molecules to a plane aidway between the two nenbrane walls.

In step 6, fast axial flow in the direction A to B through the separator tube displaces a small fraction of the fluid in the tube. This sixth step moves both the $F$ and $S$ molecules toward $B$ by the same distance, say $x_{B}$.

Over a cycle comprising these six steps, the average axial positions of the $F$ molecules and the $S$ molecules are controlled by the axial displacements in steps 4 and 6 . Because the displacements $x_{4 F}$ and $x_{45}$ are proportional to $x_{4}$, the magnitude of $x_{4}$ determines the separation distance $\left|x_{4 F}-x_{45}\right|$. Further specification of $x_{6}$ determines 
the direction of motion of the $F$ and the $S$ molecules. If, for example, we choose $x_{8}=-\left(x_{4 F}+x_{4 S}\right) / 2$, then the average distance the $F$ molecules move toward $A$ is $\left|\left(x_{4 F}-x_{4 S}\right) / 2\right|$ and the average diatance the $S$ molecules move toward $B$ is the same distance $\left|\left(x_{4 F}-x_{45}\right) / 2\right|$.

To have a zero not flow of fluid over the cycle comprising steps 1 through $6, x_{2}$ is selected to satisfy $x_{2}$ * $x_{4}+x_{6}=0$. Thus, over the six-step cycle, $F$ nolecules nove, on the average, a distance $\left|\left(x_{4} F-x_{45}\right) / 2\right|$ toward $A$; $S$ molecules nove the same distance toward $B$; and the net flow of fluid is zero.

Although the separation produced by the above cycle is aodest, repeating the cycle wany tines can result in a sharp separation with $F$ nolecules at the $A$ end of the separator tube and $S$ molecules at the $B$ end.

\section{Chronatographic Operation}

The separation can also be done in a chromatographic mode, for example, by selecting the displacenent $x_{6}$ in step 8 such that both species move toward $B$. The necessary condition is $x_{8}=k\left|x_{4 F}\right|$, where $1<k<$ inf inity. As $k-\rightarrow$ infinity, the tise of the chromatographic process becones short, but the separation between the $F$ and 5 pulses degrades. As $k \rightarrow>1$, the time of the chromatographic process grows without bound, but the separation between the $F$ and 5 pulses also increases without bound. In the above chromatographic operation, the slower diffusing species 5 energes first.

The provious examples were both batch mode and described separation of molecules of two species. The process vill actually be applied in a continuous aode and can be used sequentially in several continuous separations to separate mixtures of molecules having more than two sizes.

\section{Continuous Operation}

Continuous operation can easily be achieved by introducing the feed steadily or discretely into the separator tube at an internediate axial position, preforably where the tube and foed concentrations match nost closely, and withdrawing product streans simultaneously fros syringes $A$ and $B$.

\section{Multicomponent Mixtures}

In the batch mode, a logical extension for multicomponent mixtures is to concentrate and reaove the species one at a time in the reverse order of the magnitudes of their diffusion coefficients. However, in the continuous mode, the separation splits the feed strean into two streans and several separate separations would be required. The cut point is controlled by the selection of the axial flows. Species with diffusivities greater than the cut-point diffusivity aigrate toward $A$, and the species with diffusivities lower than the cut-point diffusivity nigrate toward 8 .

\subsubsection{Potential Energy Savings and Other Benefits}

A likely growth area over the next several decades in the United States, Japan, and Vestern Europe is biochemicals, especially therapeutic high value proteins produced using recombinant DNA approaches. A wide variety of products are under laboratory development, and product values from this new industry are estimated to total several tens of billions of dollars annually by the year 2006. Exanples products include human insulin, human growth hormone, interieukin anticancer agents, interferons for cancer and viral infections, and super oxide disnutase for limiting heart danage to blood driving reperfusion after heart attacks.

One of these products, human insulin, is already boing produced on a large scale in the United States by Eli Lilly Company using human genes in E. coli bacteria. Thirty-one steps of separation and purification are involved. The cost in capital, losses of product, consuned reagents, chromatographic packings, and other adsorbents is considerable. Of great ieportance is the yield per step. For example, a yield of $96 x$ per separation step when applied to 31 steps in series produces an overall yield of only 3.8x. All of these losses and operating costs translate into significant amounts of wasted onergy. 
If the proposed process is developed, it could dranatically reduce the cost of separations in a growing industry where separations loom as a major operating cost. Saving capital and operating costs, ospecially in consumable reagents and supplies, and increasing yields can reduce energy consumption. While estinating is difficult, we believe savings from $\mathbf{s 1}$ to $\mathbf{3 1 0}$ billion per year are feasible by the year 2900 . Engineering contributions of the type proposed here are essential to the international competitiveness of the U.S. biochenical industry as it develops recombinant DNA products.

A sinilar but saller market is the flavers and fragrances industry. The process way also be desirable for separating inorganic salts that are unusually valuable or hazardous, as in nuclear fuel reprocessing.

\subsubsection{Technical Feasibility and Impediments to Wide-Scale Use}

Because the proposed nethod of separation has only recently been conceived, its theoretical and practical characteristics are unknown. To date, a conceptual base has been established, and a theoretical analysis has been conducted based on reasonable matheastical modeling. Yet to be done are the practical design, impleaentation, proof-of-principle experiments, experimental ovaluation of process characteristics, and determination of the most pronising classes of uses.

An approximate mathematical model for the batch version of the process has been devaloped. Each of the six steps in a cyele have been described by classical equations free of unknown or adjuatable parameters. Although space liaitations do not allow the model to be presented here, the model has been used to evaluate the offects of equipment dimensions and modes of operation on performance.

Table 4.1 provides selected simulation results for an equinolar binary mixture of proteins with diffusion coefficients $0.9 \times 10^{-7}$ and $1.0 \times 10^{-7} \mathrm{~cm}^{2} / \mathrm{s}$. The table describes how a process with a separator tube thickness, $d$, and length, $L$, will perform given that the purity ratio, $R_{p}$, is attained at both onds of the separator tube and that relaxation tiee, $t_{3}$, is allowed in step 3 . These caleulation results are discussed in the following subsections along with consideration of Stariing flow, scaleup, and the inplications of the approval policies of the Food and Drug Adninistration (FDA).

\section{Cycle and Separation Time}

The cycle tiee, $T$, in Table 4.1 is the total tine of a six-step eycle. The relaxation tine, $t_{3}$, accounts for most of the cycle time. The product of the cycle time and the number of cycles, $N$, is the total time required for the separation, or the residence time. The residence time is the ratio of the separator tube volune to the volunetric flow rate of the feed.

To achieve shert cycle tines, the relaxation tine, $t_{3}$, nust be short. This relaxation time is controlled by 1) the nolecular diffusion coefficients of the proteins, assumed here to be about $\left.10^{-7} \mathrm{cn}^{2} / \mathrm{s}, 2\right)$ the thickness of the diffused layer present at the end of step 3 , and 3 ) the ratio of the diffused layer thickness to the polarized layer thickness present at the end of steps 1 and 2 . This ratio nust be about 2 or nore to achieve a reasonable separation per cyele. If the desired relaxation tine is about 1 second, the above constraints indicate a polarized layer thickness of about $2 \times 10^{-4}$.

\section{Sharpness of Separation}

Very sharp separations with high purities of both products are feasible. In Table 4.1, the processing requirements for purity ratios of 100,200 , and 500 are given. This purity ratio, $R_{p}$ is the ratio of the concentrations of species $F$ to $S$ in the F-rich product strean (tube end $A$ ) and also the ratio of the concentrations of $S$ to $F$ in the S-rich product (tube end $B$ ). Symmetrical separation has been required to ensure high product recovery as mell as high product purity. 
TAQLE 4.1. Simulation Results

\begin{tabular}{cccccccccccc}
$\mathrm{R}_{\mathrm{p}}$ & $\mathrm{t}_{3}$ & $\mathrm{~d}$ & $\mathrm{~L}$ & $\mathrm{x}_{4}$ & $\mathrm{~T}$ & $\mathrm{~N}$ & $\tau$ & $\mathrm{Q}$ & $\mathrm{C}_{\mathrm{f}}$ & $\mathrm{m}$ & $\mathrm{m} / \mathrm{V}_{\text {tube }}$ \\
\hline 100 & 1 & 0.001 & 100 & 1.20 & 1.16 & 2988 & 3463 & 10.4 & 0.040 & 416 & 41.6 \\
100 & 1 & 0.01 & 100 & 3.41 & 1.18 & 2983 & 3523 & 102.2 & 0.004 & 409 & 4.09 \\
100 & 1 & 0.02 & 100 & 6.55 & 1.21 & 2987 & 3622 & 198.8 & 0.002 & 398 & 1.99 \\
100 & 1 & 0.03 & 100 & 9.70 & 1.24 & 2988 & 3716 & 290.6 & 0.0013 & 388 & 1.29 \\
100 & 1 & 0.04 & 100 & 12.85 & 1.28 & 2988 & 3811 & 377.9 & 0.001 & 378 & 0.94 \\
100 & 1 & 0.05 & 100 & 16.00 & 1.31 & 2989 & 3906 & 460.9 & 0.0008 & 369 & 0.74 \\
100 & 1 & 0.10 & 100 & 31.80 & 1.47 & 2985 & 4394 & 823.3 & 0.0004 & 329 & 0.33 \\
& & & & & & & & & & & \\
200 & 1 & 0.03 & 100 & 8.44 & 1.23 & 3434 & 4225 & 255.6 & 0.0013 & 341 & 1.14 \\
200 & 2 & 0.03 & 100 & 6.34 & 2.21 & 3209 & 7090 & 152.3 & 0.0013 & 203 & 0.68 \\
100 & 2 & 0.03 & 100 & 7.29 & 2.22 & 2791 & 6195 & 174.3 & 0.0013 & 232 & 0.77 \\
500 & 1 & 0.03 & 100 & 7.19 & 1.22 & 4031 & 4905 & 220.2 & 0.0013 & 294 & 0.98 \\
500 & 1.5 & 0.05 & 100 & 10.05 & 1.75 & 3853 & 6726 & 267.6 & 0.0008 & 214 & 0.43
\end{tabular}

vomenclature

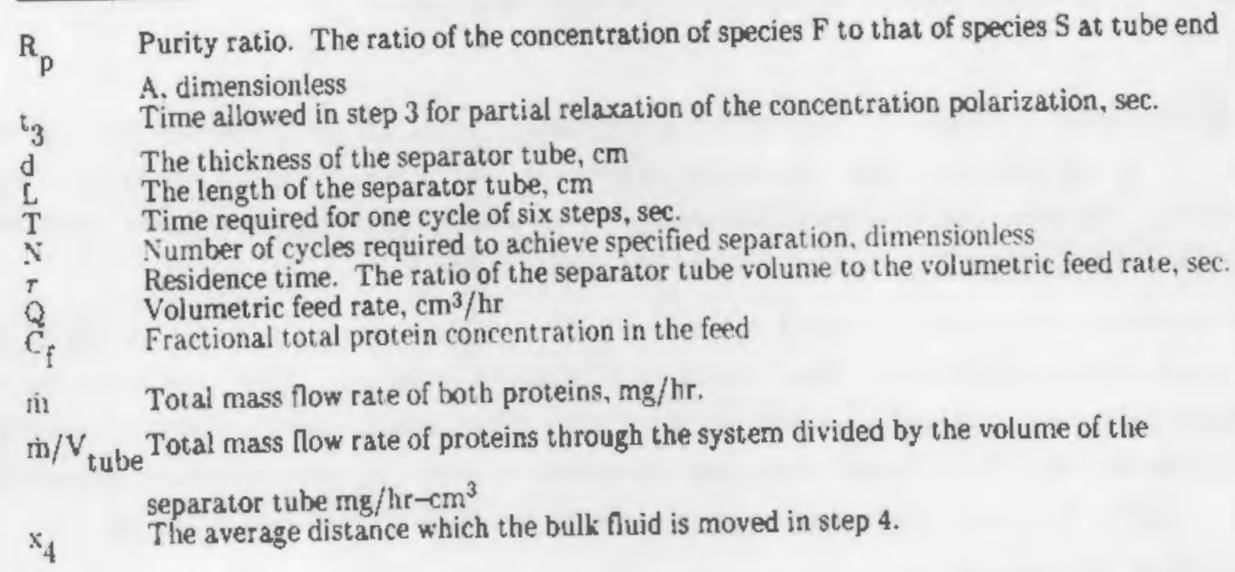

Lines 4, 8, and 11 in Table 4.1 show that high purity ratios can be achieved with reasonable processing tines. The processing tine for a purity ratio of 100 is 62 minutes. The processing times for purity ratios of 260 and 560 are 72 and 112 inutes, respectively.

\section{Waxinum Feed Prote in Concentrations}

The maximus concentration of protein that is practical in the feed is not known precisely at this time, but an order-of-magnitude estimate is $\mathbf{8 . 1 \mathrm { X }}$ to $1.0 \mathrm{x}$. This estimate is based on considering the maximum thickness that is reasonable in the polarized protein layer at the inner surface of the lower membrane at the end of step 1 and the maxinum practical concentration of protein in that layer. We ostimate that the thickness of the polarized layer should not exceed $2 x$ or $3 x$ of tube thickness so that the diffused layer present at the end of step 3 can be several times thicker but still not project beyond $19 x$ to $20 x$ of the tube width.

The naxinum concentration of protein in the polarized layer is probably from $10 x$ to $56 x$ in order to avoid blocking the cross-flow through the membrane. Assuning $2 x$ of tube thickness for the layer thickness and $26 x$ for the concentration of protein in the polarized layer iaplies a feed protein concentration of 6. 4\%. We therefore

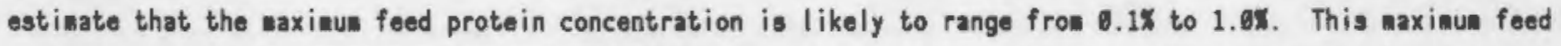
protein concentration is based on a tube thickness of $6.61 \mathrm{~cm}$. This maximun is inversely proportional to tube thickness. Therefore, thicker separation tubes require more dilute feed.

\section{Rates of Production}

A meaningful criterion for comparing rates of production is the quantity $\mathbf{i} / \mathbf{Y}_{\text {tube }}$ in the last coluan of Table 4.1, the mass of protein processed per unit tise per unit volune of separator tube. This quantity depends 
most strongly on $d$, the tube thickness. As the tube thickness is increased, the concentration of protein in the feed must be decreased in order to linit the protein concentration in the polarized layer at the end of steps 1 and 2. The reasoning for this linitation is discussed above in "Maximum Feed Protein Concentrations." Thus, although a thicker tube can process a greater volume of feed per unit tine, the mass of protein processed per unit tine does not increase.

\section{Starling Flow}

The axial flows in steps 2, 4, and 6 of the six-step cycle have associated axial pressure gradients. These pressure gradients also cause what is called Starling flow through the membrane walls. In the upstrean half of the tube the Starling flow leaves the separator tube 2 and enters chanbers 1 and 3 (Figure 4.1). In the downstrean half of the tube, the Starling flow returns from chambers 1 and 3 into separator tube 2 . Starling flow is undesirable because it degrades the separation.

Starling flow can be oliainated by flowing fluid through chambers 1 and 3 at the rate that causes the same pressure gradient along these chanbers as exists in the separator tube.

\section{Scaleup}

As al ready discussed in "Rates of Production," the processing capacity per tube does not increase by increasing the thickness, $d$, of the separator tube. Therefore, scaloup is best acconplished by sinply stacking separator tubes in parallel. The stacking arrangement automatically oliminates Starling flow in the interior tubes and conveniently enables the cross-flow to pass through the tubes in series.

Although the sinulation results in Table 4.1 show a higher production rate per unit volume of separator tube for thinner tubes, there are practical lower limits on thickness. However, little loss in production rate occurs per tube when thickness is increased. Therefore, the choice of separator tube thickness is governed by practical mechanical considerations. The thinnest tube possible should be used, in both laboratory and production-scale equipant, to minimize the total tube volune and to maximize the feed protein concentration.

\section{Inplications of FDA Approval Practices}

When the FDA approves a drug, the approval normally encompasses not only the drug's conposition, but its nethod of manufacture, including separation and purification mothods. What is approved are the reaction, separation and purification methoda used in the laboratory to manufacture the drug samples tested in the field. Later inprovenents in separation and purification methods cannot be adopted unless costly new field tests are perforaed. In practice, the methods first used in the laboratory tend to become the production mothods.

Therefore, attractiveness and widespread use as a laboratory aethod are important positive factors in promoting a separation and purification method for production. The proposed process has characteristics that wake it attractive for both laboratory and production uses. In the laboratory, flexibility, speed, and a high degree of resolution are desirable characteristics. The proposed method retains all of these attributes and is easily scaled up by stacking wany laboratory size tubes in a sandwich arrangement as discussed in the previous subsection.

\subsubsection{Current Status and Competing Technologies}

The methods of separation and purification used and presently planned for the recombinant DNA industry are of ten scaledup versions of laboratory separation aethods. Very proninent are centrifugation, precipitation, extraction, adsorption, ultrafiltration, and chromatographic separations. In the latter stages of separation very specific adsorbents, based on monoclonal antibodies, are used if the cost in dollars and time required to develop them are permissible. In addition to these existing sethods, we believe that significant research efforts are under way in the areas of electrophoresis and affinity chromatography. 


\subsection{DEVEOPMENT PROGRAM}

Two urgent steps need to be taken for the future development of the concept: 1) use the mathematical model to explore more completely feasible ranges of design and operating conditions and 2) discuss the new process with pharnaceutical companies and equipment manufacturers. Additional steps that are needed to implement widespread use of the concept are as follows:

- design and build laboratory-scale apparatus

- perfor proof-of-principle experiments on a representative binary protein mixture

- refine and validate the mathematical model

- evaluate and compare the new method against coupeting technologies for laboratory analysis applications

- design and build a prototype production-scale apparatus

- test and refine the production-scale apparatus

- evaluate and compare the new method against competing technologies for production-scale applications

- coapare econonics with current and potential future technologies

- establish suppliers and marketers of laboratory and production-scale equipment.

- provide technical support and aonitor progress.

\subsection{REFERENCES}

Bailey, J. E., and D. F. Ollis. 1988. Biochenical Engineering Fundamentals. McGraw Hill, New York.

Giddings, J. C. 1986. 'Cyclical-Field Field-Flow Fractionation: A New Lothod Based on Transport Rates.' Anal. Chen. 58:2652-2056.

Janca, J. 1988. Field-Flow Fractionation: Analysis of Macromolecules and Particles. Marcell Dekker, Ine., New York.

Wilheln, R. H., A. Rice, R. Rolke and K. H. Sweed. 1968. IParanetric Punping: A Dynanic Principle for Separating Fluid Hixturea." I.L E.C. Fund. 7(3):337-349. 



\title{
5. RECOVERY OF DILUTE AQUEOUS BUTANOL BY ADSORPTION ON LIGNIN
}

\author{
Michaol R. Ladisch, Yiqi Yang, and Christine M. Ladisch \\ Laboratory of Renewable Resources Engineering \\ and \\ Textile Science, CSR \\ Purdue University
}

\section{ABSTRACT}

This concept addresses a novel technique for concentrating dilute aqueous butanol and acetone for recovery, using lignin derived from sulfuric acid hydrolysis of bionass. Billions of pounds of butanol are produced annually from petroleun for producing plastics, solvents, and coatings. Butanol spocifically can be used in producing butyl acetate, butyl acrylate, and dibutyl phthlate. In addition, butanol is a solvent in the manufacture of oils, drugs and perfuses and in the production of urea-formaldehyde finishing compounds (Sherman 1978). The finishing compounds are videly used in the textile industry in anufacturing durable press finishing agents for cotton fabrics. Butanol also aixes well with gasoline, diesel, and regetable oil fuels. It extends water siscibility tolerance of methanol aixed in gasoline and is less sensitive to phase separation in the presence of water when wixed alone with gasoline.

Butanol and acetone were derived through the acetone:butanol:athanol (ABE) fermentation (vith Clostridiun spp. icroorganisns) before 1930. After 1930, the feraentation route was gradually abandoned because of the development of chenical processes that synthesized butanol and acetone fron less expensive petroleun. The current U.S. markets for butanol and acetone are 860 million and $1.6 \mathrm{billion}$ pounds/year, respectively. The values

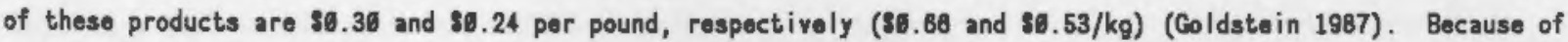
their price and volune, butanol and acetone are considered comaodities, and profitabilities are particularly sensitive to incremental changes in production costs. In producing alcohols from biomass, conmercial viability depends on developing low-cost, energy officient, recovery processes.

\subsection{INTRODUCTION}

Butanol fermentations are carried out under anaerobic conditions with Clostridiun spp. Such fermentations are the major source of butanol and acetone in South Aaerica. Before 1930, butanol produced by fermentation was also the eajor source of the alcohol in the United States. As synthetic routes were developed for producing butanol from cheap petroleun, fermentation processes were abandoned. However, a recent analysis has suggested that if production costs of formentation butanol can be reduced (Coldstein 1987), fermentation routes using Clostridiun acetobutylicun may once again be potentially conpetitive with rhodium-catalyzed petroleun routes based on hydroforation of butanol from propylene.

Butanol is not only a product of the anaerobic C. acetobutylicun fermentation, but also the major toxic substance responsible for bringing a pronature end to the ferwentation at a concentrations of ca. 1.5K (Kuhn and Linden 1987). It appears that butanol tolerance can be onhanced by eanipulating the cell menbrane's fatty acid composition. Even so, the solvent concentrations that are possibie ( $2 x$ to $3 x$ ) would still be relatively low in the context of a comercial plant. Consequently, large improvements in recovery efficiency during fermentation are needed. Siaultaneous benefits include 1) recovery of butanol, 2) higher fernentation productivity, and 3) reduced downstrean separation costs. 


\subsection{ASSESSMENT OF THE CONCEPT}

In the following sections, the proposed concept is described, and its technical feasibility, potential energy savings, current technologies, and potential markets are discussed.

\subsubsection{Description of the Concept}

Lignin is a relatively inexpensive material that occurs as a significant by-product fros biomass processing Its fuel value (based on Btu content) is about 2.5 to 4 cents/lb. If only $10 x$ of the available cellulosic biomass is converted to oxygenated chemicals through bioconversion processes, an estimated additional 10 billion pounds/yr of by-product lignin could be produced (Sundstron and Klei 1982). Lignin would be readily available in large quantities at the point of use, as a by-product of a biomass conversion process for producing butanol.

Preliminary research in our laboratory shows that lignin will adsorb butanol and acetone from dilute aqueous solution. Regeneration can result in a solution that is several-fold concentrated in butanol. This may prove significant in lowering the cost of subsequent distillation of the butanol. Nore importantly, the lignin adsorbs the alcohols but not the sugar from a liquid (aqueous) solution at ambient tenperature. Thus, by combining adsorption with the fermentation to renove the inhibiting products, butanol, and acetone as they are forned, productivity could be significantly increased. Increasing fermentor productivity has been identified as a key problen to be solved to improve the econonics of butanol production from bionass.

A typical acetone/butanol/ethanol (ABE) formentation with Clostridiun acetobutylicun yields butanol:acetone:ethanol at a molar ratio of ca 8:3.7:1 (Atkinson and Mavituna 1983). Because butanol and acetone are toxic to the microorganisn, the fermentation is stopped at a product concentration of less that $2 x$. Products other that butanol are formed and include othanol, isopropanol, and hydrogen. Lignin can selectively remove butanol, acetone, and ethanol (without removing sugar) at room conditions fron liquid solutions.

\subsubsection{Technical Feasibility}

Lignin was packed into a coluan as a dry powder using standard procedures for chronatography columns. The lignin was obtained by acid hydrolyais of black locust trees, first in $5 \% \mathrm{H}_{2} \mathrm{SO}_{4}$, under reflux, for 4 to 5 hours. The material was then washed, and hydrolyzed again for 4 to 5 hours in $20 \% \mathrm{H}_{2} \mathrm{SO}_{4}$, under rof lux. The reaaining material was washed over a Buchner funnel until the wash water was at pH 5 . The solids were then air dried. For purposes of this paper, this material will be referred to as "lignin," although this material most likely also contains residual cellulose. The effects of acid strength and other factors on hydrolysis are discussed in Bienkouski ot al. (1984). Properties of lignin obtained by acid hydrolysis have recently been characterized by Glasser and Strickland (1987).

The dimensions column were $6 \mathrm{~mm}$ in dianeter $\times 52.5 \mathrm{~cm}$ long, with a volume of $14.8 \mathrm{al}$. The outlet and inlet of the colunn were capped with a 10-micron end fitting in order to rotain the lignin. The weight of lignin packed was 10.88 grans (dry weight basis). Runs consisted of injecting 20 aicroliter sanples of 10 to $2 \pi$ solutions of the conponents shown in Table 5.1, and then eluting with water at a flow rate of $0.60 \mathrm{ml} / \mathrm{min}$ and a teaperature of $36 \pm 0.65^{\circ} \mathrm{C}$ in the type of apparatus shown in Figure 5.1. The results were used to characterize sorbent properties using standard calculations (see Ladisch, Voloch and Jacobson 1984; Neunan, Rudge and Ladisch 1987) and chromatography operating procodures (Ladisch and Tsao 1978).

The void fraction of volume external to the lignin particles was 8.40 (based on dextran). Most of the pores appear to be smaller than about 20 to $30 \&$ (based on polyethylene glycol (PEC) elution). The internal and external void fraction of the colunn is about 9.63 (based on $\mathrm{NaCl}$ ). There is little or no adsorption of glucose (separates at about the same tine as $\mathrm{NaCl}$ ), and strong adsorption of butanol (separates at $27.2 \mathrm{nl}$ volune), with an estimated capacity factor for butanol of 3.6 (which is quite large). Based on an analysis first presented by 
TABLE 5.1. Elution Voluse of Conponents Injected into a Colunn Packed with Lignin

\begin{tabular}{|c|c|c|}
\hline Component & $\begin{array}{l}\text { Wolecular } \\
\text { Woight }\end{array}$ & $\begin{array}{c}\text { Elution } \\
\text { Volune (n) }\end{array}$ \\
\hline Dextran & 5 to $46 \times 10^{8}$ & 5.9 \\
\hline PEG & 29,609 & 7.4 \\
\hline $\mathrm{NaCl}$ & 58.5 & 9.4 \\
\hline D-Glucose & 180 & 9.9 \\
\hline $\mathrm{MeOH}$ & 32 & 11.0 \\
\hline EtOH & 46 & 11.8 \\
\hline Acetone & 58 & 15.7 \\
\hline ВuOH & 74 & 27.2 \\
\hline
\end{tabular}

Lapidus and Amundson (1956), the volume of feed, $\nabla$, which will saturate a column packed with adsorbent, is given by

$$
\nabla=V_{0}+K V_{s}
$$

This assunes linear equilibriun. The paraneter $\boldsymbol{\nabla}$ represents the point of inflection on a breakthrough curve, and coincides vith the peak maximum of chronatographic peak for a small sample size. On this basis, a first measure of coluan capacity can be estinated for the alcohols and acetone, based on $\nabla$, and assuning that the breakthrough profile is sharp. The result is as follows (data fron Table 5.1):

$$
\begin{aligned}
x & =\frac{\left(\nabla-v_{0}\right)\left(0.01 \frac{\text { g butanol }}{! !}\right)}{16.8 \mathrm{~g} \text { lignin }} \\
& =\frac{(27.2-5.9 \mathrm{al})\left(0.01 \frac{\mathrm{g} \text { butanol }}{\mathrm{l}}\right)}{10.8 \mathrm{~g} \text { lignin }} \\
& =0.02 \frac{\mathrm{g} \text { butanol }}{\mathrm{g} \text { lignin }}
\end{aligned}
$$

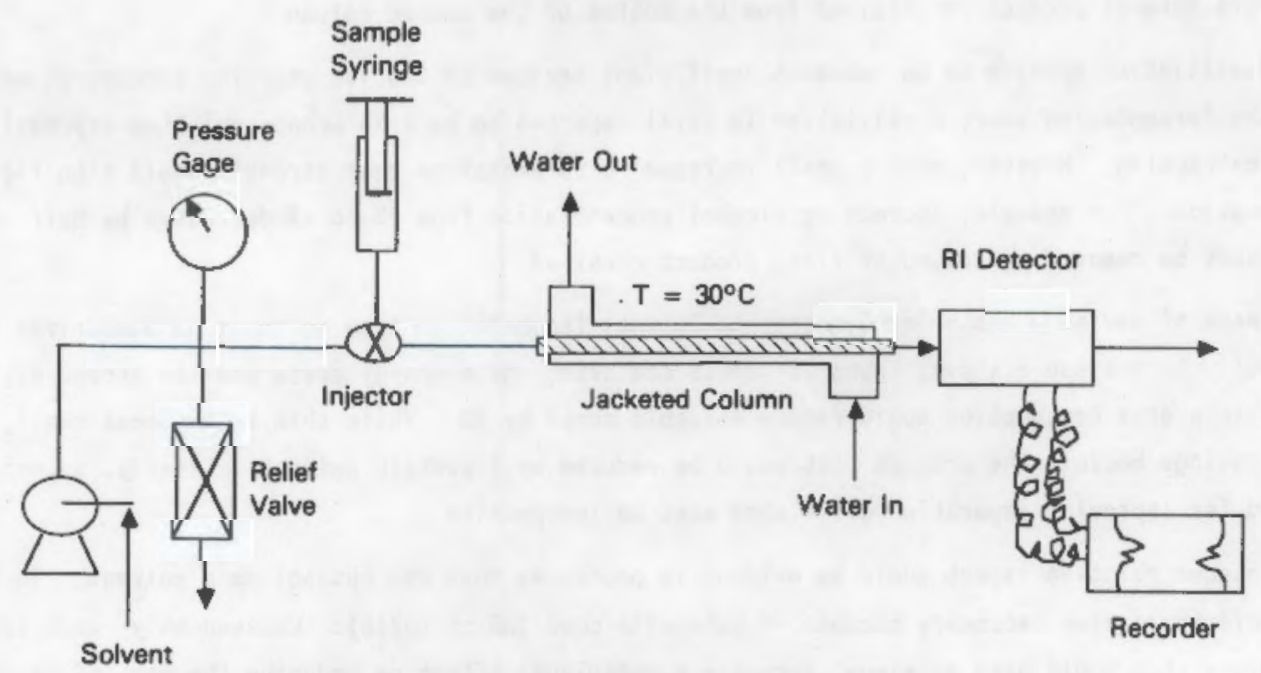

FICURE 5.1. Apparatus for Evaluating Lignin Adsorption Propertios 
(i.e., the loading is $2 x$ ). On a similar basis the capacities for acetone, ethanol, and methanol were estimated to be:

- methanol - $6.5 \%$

- ethanol - 6.58x

- acetone - .9.9\%.

The apparent capacity is expected to increase significantly with decreasing tenperature and increasing alcohol concentration. If the adsorbent proves stable under repeated use, its cost could be negligible. For example, the assuning lignin is used for 100 cycles, the sorbent cost per pound of butanol recovered would be about 1 cent.

Other preliminary research shows that adsorption and regeneration with hot $\mathrm{CO}_{2}$ (a gas) yields an $8 x$ alcohol product (wich is 4 times as concentrated as in the bear). After regeneration, the lignin still retains adsorption capacity. Thus, the possibility exists that a relatively inexpensive adsorbent obtained as a by-product of biomass hydrolysis can be used in connection with an ABE fermentation to adsorb alcohols as they are formed and increase productivity by relieving inhibition. The research reported here ovaluates improvenents in the officiency of the acetono/butanol/ethanol (ABE) fermentation based on the assunption that an adsorption process is combined with the fermentation. The offect of adsorption characteristics on inproving energy officiency and econosic potential of the ABE fermentation is discussed in the following section.

\subsubsection{Potential Energy Savings}

The behavior of butanol and water is complex. At concentrations bolow 3 mol $x(11.3$ wgt $x)$ and above $40 \mathrm{nol} \times(73.3 \mathrm{gt})$, the liquid composition is hosogeneous (i.e., single phase). Between these concentrations two layers will form in the liquid phase. At equilibriun the compositiona of these phases are 3 nol $\mathbf{x}$ butanol for the bottom layer and $40 \mathrm{~mol} \times$ for the top layer. At $25 \mathrm{~mol} \times(57.8 \mathrm{wgt} \mathrm{n})$, a heterogeneous azeotrope forms and thus the vapor and average liquid compositions are equal. However, the liquid at 25 mol $x$ mill be separated into two layers with one layer at $3 \mathrm{~mol} \times$ and the other at $40 \mathrm{~mol} \times$. Traditional distillation involves diatilling off neutral solvents (butanol, acetone, and othanol) with sone water fron the fernentation of beer. The overhead vapor is condensed. The resulting liquid separates in a decanter into two phases (since the butanol concentration is between 3 and $400 \mathrm{~m}$ ). The lower phase is returned to the first distillation column while the upper phase is fed to subsequent colunns for further purification. In the case of butanol and water alone, the renaining water with some butanol is boiled off in a second colunn. This vapor ie condensed and returned to the decanter. Pure butanol product is obtained fron the bottion of the second colunn.

While distillation appears to be somerhat inefficient because of the low starting concentration of neutral spirits in the fermentation beer, distillation is still reported to be more econonical than crystallization or traditional extraction. However, even a suall increase in fermentation beer strength would significantly reduce energy consumption. For example, increasing alcohol concentration fron $2 \pi$ to $4 \%$ decreases by half the anount of water which must be removed per pound of final product obtained.

An estimate of variable costs for the acetone-butanol fermentation from molasses is summarized in Table 5.2 (Hacking 1986). As the table shows, substrate costs doninate, while energy costs are the second major item. A 50x decrease in energy consunption would reduce variable costs by 5\%. While this value seens anall, it is a significant savings because the product cost would be reduced by 1 cent/lb solvent. Clearly, an econonically viable method for iuproving separation officiency must be inexpensive.

A much bigger relative inpact would be evident in processes that use butanol as a solvent. In this case solvent recycle would seen necessary because of butanol's cost (30 cents/lb). Consequent/y, cost savings in the solvent recovery step would have an aleost directly propertional affect on reducing the cost of using the solvent. 
TABLE 5.2. Approxiante Variable Costs per $1060 \mathrm{~kg}$ Solvent (a)

\begin{tabular}{|c|c|}
\hline Wolasses, 5 te ${ }^{(b)}$ at $58 \sigma /$ te & 8406 \\
\hline Aasoniua Sulphate, $168 \mathrm{~kg}$ at $380 /$ to & 8 \\
\hline Calciun Carbonate, $140 \mathrm{~kg}$ at $850 /$ te & 7 \\
\hline Stean, 2.25 te at $326 /$ to & 45 \\
\hline Total & 3460 \\
\hline $\begin{array}{l}\text { (a) Refers to acetone - butanol } \\
\text { (b) Hetric ton. }\end{array}$ & \\
\hline
\end{tabular}

The overall manufacturing cost of butanol will be 80.36 to $89.4 \%$ /pound in an economically viable process (Coidstein 1987). The estinated costs of current process technologies are two to three tians higher, according to Coldstein, in part due to low formentor, volumetric productivities. Adsorption of the alcohols by lignin may also increase productivity, by partially resoving inhibition and thereby lowering fermentation costo.

\subsubsection{Current Technologies}

The practical and technical option for butanol recovery appears to be distillation, which was suamarized in Section 5.2.2. Another option recently described in the literature involves using liquid menbranes to concentrate butanol and acetone by pervaporation (latsunura and Kataoka 1987). That process ontails supporting oleyi alcohol on a hydrophobic nenbrane. In this systen, concentration of butanol from $0.4 \%$ to $49 \%$ was reported, vith the membrane having a separation factor (butanol/water) of 180 and an operational stability of at least 160 hours. The liquid menbrane systen is technically interesting, but at this time information on meabrane cost is insufficient, particularly concerning potential oleyl alcohol losses and the cost of these losses.

\subsubsection{Potential Markets}

Markets for adsorption technology using lignin include feraentation processes that produce butanol and industrial processes that use butanol. Those markets include the following:

1. fermentation processes for butanol production (a long-tere prospect because the United States currently has few, if any, coneercial plants).

2. dehydration and recovery of butanol in order to recycle the alcohol in an alcohol pulping process

3. general solvent recovery of water discharge streans containing low lovels of butanol.

Other uses will becone apparent as research proceeds.

The emphasis of bionass research in recent years has been on the converting cellulosic residues to ethanol. However, the sugars obtained from biomass can be fermented to other key products, including acetone and butanol, which are "building blocks" for the chenical industry. Examples of key interaediates that can be derived fron butanol and acetone include butyl acrylate, butyl acetate, and methyl methacrylate. Therefore, depending on the selectivity of a lignin adsorbent, this technology may find use in these other applicationa.

\subsection{FUTURE CONCEPT DEVELOPUENT}

Industrial-scale fermentation is currently carried out in South Africa using $C$. acetobutylicum in the Woizann Process to produce ABE in a two-day formentation. On a wight basis, this formentation produces butanol:acetone:ethanol in a 6:3:1 ratio with $\mathrm{CO}_{2}$ and $\mathrm{H}_{2}$ as the other by-products. The yield of major products based on the sugar formented is $39 x$ solvents, $50 \% \mathrm{CO}_{2}$, and $2 x \mathrm{H}_{2}$. The characteristics of the microorganism are 
such that during the exponential grouth phase, acid production predoninates; whereas, during the stationary phase, solvent production is enhanced. The pH of the fermentation also affects the types of products formed. At high pH conditions, organic acid production is enhanced; at low pH solvent, production is favored. As the discussion above indicates, the fermentation nust be carefully controlled to obtain the desired product. Inhibition of the fermentation is the najor practical problen.

If the lignin is to be useful in a practical adsorption process, it must be capable of boing regenerated. Desorption using $89 x$ ethanol at $20^{\circ} \mathrm{C}$ gave good results. When excess liquid in the colunn was blown out with air and then a volune of $4.5 \mathrm{al}$ of $89 \mathrm{x}$ ethanol was passed through the coluan at $20 \%$, all of the butanol (as deternined in experinental accuracy) was washed out. Surprisingly, the butanol desorbed initially was concentrated by a factor of almost two tines. The desorption curve obtained was quite sharp. This run showed not only that the lignin could be regenerated but also that the butanol is separated in a nore concentrated fora. Further offorts are now needed to characterize desorption characteristics, and adsorbent stability. Studies with feraentation broths that contain cell debris and other aedia components also need to be conducted.

\subsubsection{Steps Innediately Required}

Our prelisinary research has shown that lignin has the potential to solectively adsorb butanol, acetone, and perhaps ethanol from fermentation broth containing augar and salts. After adsorption, the lignin can be regenerated by passing $\mathrm{CO}_{2}$ gas at $99^{\circ} \mathrm{C}$. The lignin was shown to retain its adsorption capacity after regeneration with $\mathrm{CO}_{2}$. Further prolininary runs are now needed to define adsorption capacity and to specify an approximate range of desired operating conditions.

\subsubsection{Additional Steps Needed for Inplenentation}

Prolininary research confiras the hypothesis that lignin sorption of butanol can signifieantly reduce butanol production costs. Further developmental offort should be vigorously pursued. Specifically, engineering data for designing large-scale systeas should be obtained, and a scaleup trial should be pursued. Other sources of lignin from the pulping industry should also be oxanined.

If scaleup trials are successful, the next step would be to seek a suitable conpany that either manufactures butanol or needs to recycle this solvent. At the sase tiee, a conpany should also be identified that can build turnkey sorption systens and provide technical services to users of a lignin sorption systen. Negotiations on technology transfer could than be initiated.

\subsection{REERENCES}

Atkinsen, B., and F. Mavituna. 1983. Biochenical Engineering and Biotechnology Handbook. Nature Press, UacMillan Publishers, Great Britain.

Bienkorski, P., M. R. Ladisch, M. Voloch and G. T. Tsao. 1984. 'Acid Hydrolysis of Pretreated Lignocellulose fron Corn Residue.' Biotechnol. Bioeng. Symp. Ser. 14:512.

Glasser, 1. G. and R. C. Striekland. 1987. IProliainary Evaluation of an $\mathrm{H}_{2} \mathrm{SO}_{4}$-Wood Saceharification Lignin for Use in Phenolic Resins.' Bionass. 13(4):235.

Coldstein, ע. E. 1987. "Econonic Facters in Relationship to Specialty Chenical Products by Biocatalysis." Biotechnol. Bioeng. Syap. No. 17:783.

Hacking, A. J. 1988. Eeononic Aspects of Biotechnology. Canbridge University Press, Canbridge, England.

Kuhn, R. H., and J. C. Linden. 1987. "Effects of Tenperature and Lanbrane Fatty Acid Composition on Butanol Tolerance of Clostridiun acetobutylicun." Biotechnol. Bioeng. Syap. No. 17:197.

Ladisch, M. R., and M. Yoloch and B. Jacobson. 1984. "Davelopeents in Bioseparations." Biotechnol. Bioeng. Symp. Ser. No. 14:512.

Ladisch, M. R., and G. T. Taao. 1978. Theory and Practice of Rapid Liquid Chromatography Using Water as Elvent." J. Chromatogr. 168:85. 
Lapidus, L., and M. R. Anundson. 1952. Mathenatics of Adsorption in Beds.' J. Phys. Chen. P. 984.

Hataunura, M., and H. Kataoka. 1987. 'Separation of Dilute Aqueous Butanol and Acetone Solutions by Pervaporation Through Liquid Mosbranes." Biotechnol. Bioeng. 36:887.

Neuman, R. P., S. R. Rudge and U. R. Ladisch. 1987. ISulfuric Acid-Sugar Separation by Ion Exclusion." Reactive Polyeers. 5:55.

Shernan, P. D. 1978. 'Butyl Alcohols." In Encyclopedia of Chenical Technology, Vol. 4, ed. H. F. Mark, D. F. Othaer, C. G. Overberger, and G. T. Seabery, J. Wiloy and Sons, Inc., New York.

Sundstroe, D. M., and H. E. Xlai. 1982. "Use of By-Product Lignins from Alcohol Fuel Processes." Biotechnol. Bioeng. Syap. Ser. No. 12:45-58. 

WASTE/FUE RECOVERY 


\subsection{POTENTIAL FOR BROADER APPLICATIONS OF EXTRACTING HYDROCARBONS USING LIQUID-CORE POLYAPHRONS}

\section{Felix Sebba Gerhard H. Beyer Donald L. Michelsen}

Department of Chemical Engineering

Virginia Polytechnic Institute and State University

\section{ABSTRACT}

A proposed concept is being developed to extract the bitumen from tar sands at low tenperatures using liquid butane nade up into a water-continuous polyaphron as the extractant. The sand breaks up the polyaphron so that the mixture separates into three layers: sand at the bottom, an internediate aqueous layer, and a butane-bitumen solution on top, which can easily be separated fron the other layers. Fron that solution, the butane can be boiled off and recovered to be reliquefied and reused. This should be a cheaper procedure than the hot water extraction nethod currently in use.

Evaluation of the proposed concept revealed the following:

1. Tar sands represent a significant energy reservo.

2. Hot water extraction as practiced in Alberto is energy intensive and unique in that many tar sands require different treatment.

3. Aphrons made of kerosene or butane can effectively renove bitunen fron tar sands that are not suited to hot water treatment.

4. Liquid butane in polyaphron fora as the extracting solvent has potential for simple cold separation and can be recycled.

\subsection{INTRODUCTION}

Many countries have vast reserves of hydrocarbons that are tied up in a highly viscous structure ranging from deformable oily sands to rock-like tar sands. These hydrocarbons are known as bitumen, tar, oil, or sometimes as heavy crude sands. They are characterized by an organic component that is valuable but virtually inmobile because of its high viscosity. The structure of this component is made up of high-molecular-weight carbonaceous chenicals containing less hydrogen than occurs in crude oil. Enbedded in this mass is a considerable quantity of inorganic mineral matter made up of sand, silt, and clay with a small anount of kerogen, a solid organic residue that is insoluble in aost solvents.

Recovering the bitumen, as the sticky organic matter is sometimes called, poses a considerable engineering problem because its high viscosity makes it difficult to separate from the inorganic particles which, being finely divided, tend to adhere firmly to the bitumen. It is important to distinguish between these minerals and oil shales which contain virtually no oil, just kerogens. The proposed concept cannot be used for extraction froa oil shales.

Tar sands are common in many regions containing oil deposits. The largest deposits are found in Venezuela, although they do not appear to have been conmercialized. The North American continent has vast deposits in Alberta, Canada, where commercialization is occurring. Considerable, but little known, deposits are found in the central part of the United States, particularly in Utah, but these too have not yet been comnercialized. Kentucky also has considerable deposits, but past attempts to develop then have failed and no further attempts appear to have been made. 


\subsection{EXISTING TECHNOLOGY FOR RECOVERING BITUMEN}

The only comercially successful method for separating the bitunen from the sand is operating in Alberta, Canada. That nethod involves reducing the bitusen's viscosity by raising the temperature using stean, until the droplets of oil coalesce, and then separating the oil droplets fron the inorganic material. However, this methods only works on the type of deposits found in Alberta, where the inorganic mineral is sheathed in a very thin aqueous layer that separates the mineral from the oil. That type of deposit is unusual; in many deposits, the oil itself wets the minerals so that separation involves the step of replacing the oil adhering to the surface of the mineral with water.

A second problem with the existing method occurs after the separation stage and poses a possible environmental hazard. Because the clay particles are so smail, they tend to reain suspended in the water and are very difficult to flocculate or settle. The wash water therefore cannot be discharged into rivers and requires very large dans for storing the offluent.

\subsection{CONCEPT DESCRIPTION}

The viscosity of bitumen can be reduced by using a solvent in the form of a polyaphron biliquid foan. If liquid butane is used as the solvent (instead of kerosene, for example) in the biliquid foam, the solvent can be recycled without consusing much energy.

In the following sections, the feasibility of using polyaphrons for extraction is discussed in general. That discussion is followed a more detailed discussion of kerosene (used in earlier experiments) and then liquified butane as the solvent.

\subsubsection{Polyaphrons}

Biliquid foans exist, in which a nonpolar liquid, instead of gas bubbles, are found in the spaces between the continuous aqueous layers. The nonpolar liquid, like a gas bubble, is oncapsulated in a thin soapy fila. A polyaphron is a concentrated biliquid foan that can contain up to $96 \%$ of the nonaqueous phase dispersed in water in globules that have wicron or subaicron dianeters (Sebba 1984). Such polyaphrons are stable enough to last for years, but will break under certain conditions. Because of those conditions, kerosene-based polyaphrons are opening up a novel extraction method that of fers many advantages.

By juxtaposing minute kerosene globules to a detergent solution that can wet the solids and coat then, the oil can be prevented froe re-adhering to the solids. This offectively is the sase as the detergency process known as "rolling up." Although the encapaulating soap file surrounding the aphron is very tenacious, it is readily broken on contact with a hydrophobic material. In this way, the kerosene becones available to dilute and mobilize the bitumen. However, the ingredients for making aphrons are still there, so the aphrons can be spontaneously reconstituted and reused (Sebba 1984, 1987).

The polyaphrons used in recovering bitumen must fulfill two requirenents, so not all types of polyaphrons are equally suitable. The first requirement is that the surfactant in the aqueous phase nust not have a tendency to adhere to the solid mineral with the hydrophobic end facing outward. That adhesion would anke the solid nonwettable by water and would introduce a tendency for the oil to wet it. Because clays and silica are usually negatively charged, cationic surfactants cannot be used. Because their head groups are negatively charged and therefore repelled by the negatively charged solids, anionic surfactants could be used; in particular, sodiun dodecylbenzene sulfonate has been found useful because it stabilizes good polyaphrons. The second requirenent is that the oil used in the polyaphron must have a good solubility for the bitumen and be relativaly cheap. Kerosene has shown itself able to fulfill these requirements. 


\subsubsection{Effectiveness of a Kerosene Polyaphron Extraction}

Considerable, as yet unpublished, work has demonstrated the effectiveness of the extraction on many different samples of tar sands, both from the United States and Canada. When the extraction is performed batchuise in beakers, the residual sand has been found to be virtually free of oil.

A continuous process using a revolving tube, somewhat like a coment nixer, has been developed and tests to date have been most encouraging. However, one economic difficulty needs to be overcome: the amount of kerosene needed to liquefy the bitumen and the amount of bitumen that is recovered is about the same. Recovering the kerosene for reuse would require a distillation process that would add onergy costs to the process. Nevertheless, the polyaphron extraction might prove to be preferable to present extraction aethods because it is a cold process.

If the extract were to be used as a fuel oil and burnt, the kerosene may not need to be recovered. However, a possible alternative that would allow the solvent to be recycled without consuning much energy uses liquefied butane in polyaphron fors as the extracting solvent.

\subsubsection{Extraction by Liquid Butane}

Butane has a boiling point of $-6.3^{\circ} \mathrm{C}$, and is a liquid at pressures above 2 atmospheres at room temperature. Experiments have shown that liquid butane, just like any hydrocarbon, can be converted into a polyaphron. It has also been shown that other hydrocarbons such as hexane, gasoline, and limonene can extract bituaen from tar sands. Experinents have confirmed that a butane polyaphron can behave in a siailar way. The butane polyaphron has to be produced and extracted under pressurized conditions, if performed at roon teaperature, but the pressure required would be low enough not to present any problens.

The advantage of using butane as the solvent is that when the extract is decompressed to atmospheric pressure, the butane boils off and can be recompressed and reused. The energy savings should be significant. However, if the butane is kept below its boiling point of $-5.3^{\circ} \mathrm{C}$, it can be converted into a polyaphron at anbient pressure.

Procedure for Extraction by Butane

Butane, obtained fron a cylinder, has been converted into a polyaphron by the following procedure:

1. One hundred $a l$ of butane was transferred into a stoppered conical flask already containing 0.5 al of tergitol 15-S-3, an oil soluble non-ionic surfactant, which was resting in a cold bath at $-5^{\circ} \mathrm{C}$.

2. Another sinilar flask cooled to the same temperature hold 5 al of water containing the surfactant dodecylbenzene sulfonate at a concentration of $5 \mathrm{~g} /$ lliter.

3. The solution in this second $f$ lask was converted into a foan by shaking the flask. The butane was then added by shaking only a fow drops at first, but increasing the amounts in an approximate geonetric progression. This method fairly quickly incorporated all the butane into the water in the form of a biliquid foan. This produced a product in which the butane globules were no more than a few microns in diameter, encapsulated in a thin soapy file and dispersed in the aqueous phase in the form of a biliquid foan, or polyaphron. As long as this biliquid foam was kept below the boiling point of the butane, it renained stable.

4. Ten grams of tar sands obtained from Utah were broken into nuggets about the size of small nuts sinply by hamer blows. (Mechanical crushing of tar sands into smaller fragnents is not easy because of the plastic nature of the matrix.)

5. After they were precooled, these nuggets were shaken into the previously prepared polyaphron and shaken vigorously for a few minutes, taking care to keep the mixture cold.

8. The aphrons immediately attacked the tar sands, liquefying the bitumen because of the presence of the butane, and thus liberating the sand that becane wetted by the water, which in turn displaces the bitunen. Adding a 
further small amount of water allowed the bitumen to be completely separated from the sand. Because the bitumen is lighter than water, it floated above the surface of the water.

7. The mixture quickly separated into three clearly denarcated layers:

- the sand settled on the botton, al ready renarkably clean

- water containing sone dispersed clay and a saall amount of colloidal oil globules formed the internediate layer

- the major part of the oil floated on the surface of the water, where it could easily be removed.

If the teaperature were raised to ambient temperature, the butane could be distilled from the bitunen, recondensed and converted into a polyaphron, and recycled.

Although the residual sand was very clean, some black particles were dispersed through it. At first these particles were thought to be residual tar sands and therefore the separation to be incomplete. It was later found that the actual quantity of oil in the particles was minute. In fact, these particles turned out to be water globules coated with a thin layer of sand mixed with oil, which proved to be an effective barrier to the coalescence of the water giobules.

These structures have some resenblance to what have been called invert aphrons, that is water globules stabilized by a thin coating of minute aphrons. Grinding these particles with polyaphrons broke then up, but the quantity of oil recovered in this way most likeiy would not justify this further treatment. Because the number of particles renaining fron the procedure seen to increase as the quantity of dilution water increases, only as much water as would enable the bitumen-butane solution to be floated should be used.

The efficiency of the extraction process was shown by another experiment. Thirty-five grams of tar sands fron an unknown source in Colorado were shaken with $80=1$ of a butane polyaphron of PVR 10. (PVR or phase volune ratio is the ratio by volume of oil phase to the water). The tenperature was kept at $-5^{4} \mathcal{C}$. After the liquid was decanted off, another 86 al of the polyaphron was added and the process repeated. The oil was removed by decantation after a saall quantity of water was added. After the sand was dried and weighed, it was found that $69 \%$ of the oil had been extracted.

\subsection{POTENTIAL ENERGY SAVINGS}

If butane polyaphron extraction method can be made operational, considerable energy should be saved compared with the current state of the art. The method practiced in Alberta uses stean that has to heat up not only the bitumen but also the underlying sands. Because these comprise $90 \%$ of the tar sands, considerable amounts of heat are wasted. Butane extraction would work at ambient tenperature if the operation were conducted under slight positive pressure and then boiled off simply by reducing the pressure. Some energy would be consuned in compressing the butane, but this physical process at such a small pressure requires considerably less energy than does stean generation or distillation.

A possible spinoff of this work, although not undertaken in this project, is that it could provide preliminary experience on pressurized polyaphrons, which would encourage future work on using butane polyaphrons, or possibly carbon dioxide polyaphrons, for tertiary oil recovery. Unfortunately, in the oil recovery industry many factors besides technological problems prevail, such as politics and econonics.

The price of oil will eventually increase, which will allow alternative sources to be exploited and nake tar sands a competitive source of oil. This novel extraction technology might make it conpetitive now. Most important, however, is that oil is a limited but vital resource in any country, and tar sands provide an alternative source that is available in large quantities in some countries, including the United States. Therefore, this country should be in a position to develop this alternative resource at very short notice, if the need arises. 


\subsection{FUTURE DEVE}

Further experience with this extraction method is expected to significantly improve its officiency. This method, like the hot water extraction, has the disadvantage that the water layer still contains sone finely dispersed oil and clay. This can be removed by a combination of colloidal gas aphron flotation and flocculation by aluninum ions, such as has been offectively used for cleaning the waste waters in Florida phosphate operations.

It must be stressed that, when working in the area of surfaces, extrapolation may be wisleading. For exaaple, it would be thought that if the aphrons were made snaller the extraction would become nore efficient. Experinents have disproved that idea because the encapsulating soap filn has to be broken to release the solvent that is to liquefy the bitunen. This fila is broken because fine spikes of hydrophobic tar sand, when they touch the outer surface of the soap $\mathrm{film}$, create a high contact angle and penetrate the soap filn, breaking it. If, however, the aphron is snall compared with the irregularities on the tar sand, geonetric considerations will prevent this penetration, and the process will not work. For that reason, the procedures suggested in this proposal nust be tested experimentally.

\subsection{REFERENCES}

Sebba, F. 1984. 'Proparation and Properties of Polyaphrons (Biliquid Foans)." Chen. and Ind. p.387.

Sebba, F. 1987. Foans and Biliquid Foans-Aphrons. John il loy and Sons, Chichester, Engiand. 



\subsection{FUE FROM MUNICIPAL SLUDGE}

Janes H. Johnson, Jr., Ranesh C. Chawla, Joseph N. Cannon Manadou S. Diallo, Lily tan, and Kenneth G. Henley

Howard University

School of Engineering

\section{ABSTRACT}

A proposed process is being assessed for separating a significant fraction of organic aaterial from municipal sludge by acid extraction and for reconstituting the extracted organic material as a solid fuel. Organic conpounds that have unshared electron pairs or unsaturation in the form of double bonds or conjugated double bonds protonate and dissolve in concentrated protonating acids, such as sulfuric acid. These dissolved organic compounds can be recovered unchanged, by precipitation, when diluted with water.

Experinental results demonstrated that $86 x$ of the solids can be dissolved during acid oxtraction, and up to 25\% of the initial solids can be precipitated when diluted vith water. The precipitated product was a high organic (96x to 98x) solid and represented up to $36 x$ of the initial organics. Prelininary econonic estimates show this process to be conpetitive with other sludge disposal and reuse alternatives for wastewater treatment plants serving one million people or more. The economic picture can be greatly iaproved by incorporating the negative cost of sludge disposal.

The assessment results suggest that future work is needed to optiaize the protonation process and operating conditions, to select and design an acid recovery system, and to recover and reuse the inorganic residue. The proposed activities would provide a basis for a detailed econonic analysis and pilot plant design.

\subsection{CONCEPT ASSESSMENT}

In the following sections, the results of the prelininary concept assessment are presented. First, the proposed concept is described. Then, the results of the analyses of its technical feasibility and econonics are discussed. Finally, current and competing technologies and potential markets for the concept are described.

\subsubsection{Description of the Concept}

Thermal energy recovery from wastewater sludge by direct conbustion is theoretically achievable for woisture contents as high as $26 x$. However, because of the high ash content of the sludge (26x to $36 x$ ), its fuel value is very low. The purpose of the proposed concept is to separate a significant fraction of the organic material fron the sludge by extraction and to reconstitute the extracted organic aaterial as a solid fuel.

When sludge (a mixture of organic and inorganic compounds) is contacted with an acid (in this case, sulfuric acid), the acid may behave as a solvent or reactant, or aay have no inpact on the organic naterial. The nost desirable option for producing a high-grade solid fuel is to solubilize the organic fraction of the sludge. Solubilization allows the organic fraction of the sludge to be dissolved and reconstituted as a solid in a dilute (sulfuric) acid solution. Concentrated sulfuric acid, in behaving as a solvent, resenbles water in that it selfprotonates to produce acidic $\left(\mathrm{H}_{3} \mathrm{SO}_{4}{ }^{+}\right)$cations and basic $\left(\mathrm{HSO}_{4}{ }_{4}\right.$ ) anions. When an organic coupound is placed in a highly protonating solvent (such as sulfuric acid), the hydrogen ion from one nolecule of sulfuric acid will often preferentially protonate the organic molecule rather than another molecule of sulfuric acid, as shown in Equation 1.

$$
\mathrm{RNH}_{2}+\mathrm{H}_{2} \mathrm{SO}_{4} \rightleftharpoons \mathrm{RNH}_{3} \cdot \mathrm{HSO}_{4}^{-}
$$


Organic compounds that have unshared electron pairs available for bonding and compounds that have unsaturation in the form of double bonds or conjugated double bonds protonate and dissolve in concentrated sulfuric acid (Liler 1971), as shown in Equation 1.

To use the dissolution character of organic materials in concentrated sulfuric acid, it is necessary to protonate (dissolve) the organic conpounds, separate the dissolved from the undissolved materials, deprotonate (precipitate) the dissolved organics, and separate the precipitate fron the deprotonating liquid. The proposed process flowsheet, shown in Figure 7.1, includes facilities for sludge and acid storage, protonation and deprotonation reactors, a settling tank, two centrifuges, a dryer, and storage facilities for final product and undissolved residue. All proposed processes use standard unit operations equipment that has protection against acid corrosivity. No details of the acid recovery systen are included at this time.

\subsubsection{Technical Feasibility}

The technical feasibility of the proposed process concentrated on three ajor areas:

- identifying offective acid solvents

- establishing reasonable operating conditions

- determining the product's recovery and conposition.

Each areas is discussed below, followed by a discussion of two process impediments that were identified.

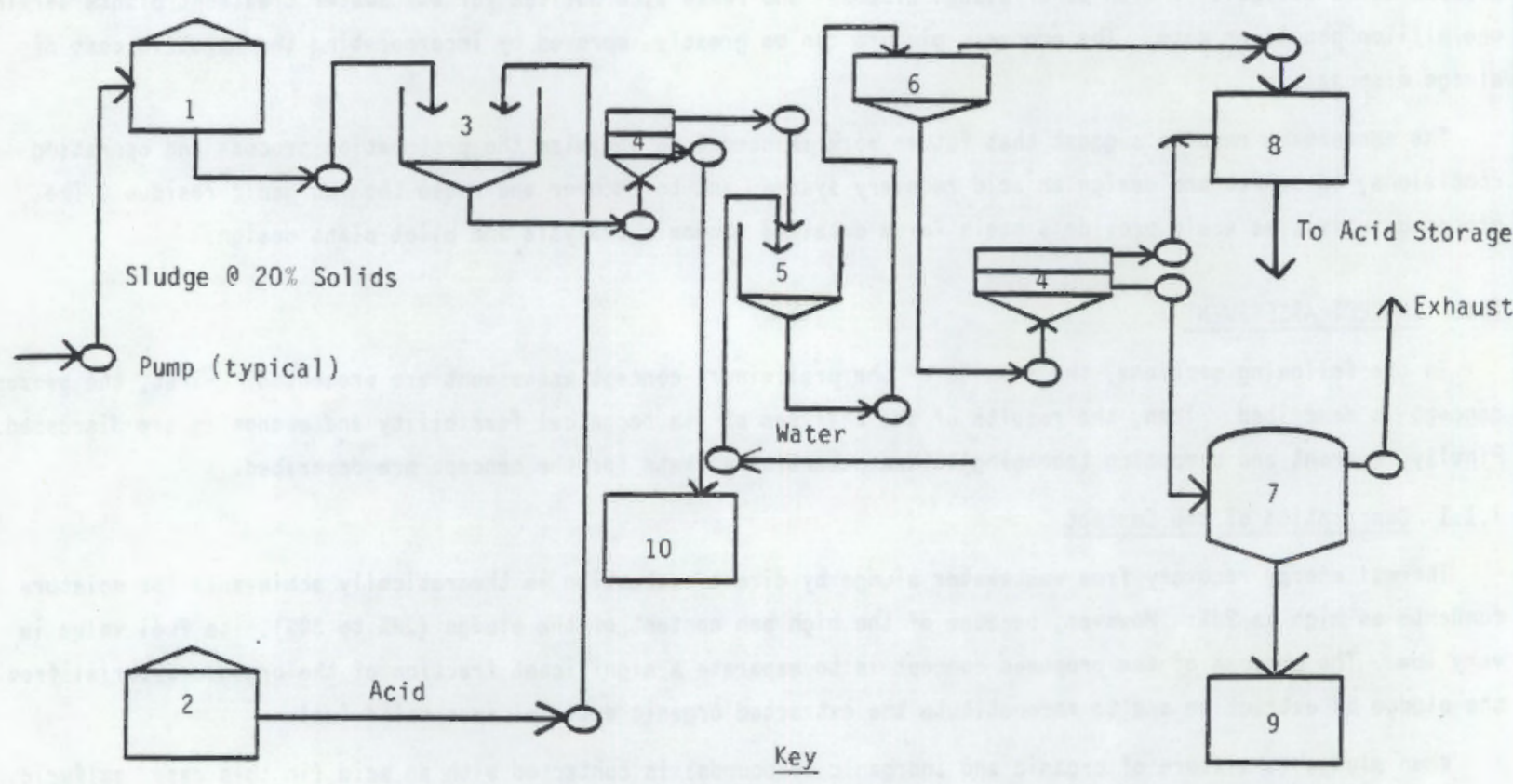

1. Sludge Storage Tank

6. Settling Tank

2. Acid Storage Tank

7. Dryer

3. Protonation Reactor (Mixer)

8. Acid Recovery System

4. Centrifuge

9. Dried Product Storage

5. Deprotonation Reactor

10. Solid Residue Storage

FIGURE 7.1. Flowsheet for a Proposed Sludge-to-Solid Fuel Processing Plant 


\section{Identifying Effective Acid Solvents}

An extensive literature search was conducted to identify acid solvents that would selectively oxtract the organic fraction fron municipal sludge. The search identified several articles (Gillespie and Leisten 1954; Gillespie and Robenson 1959) and a comprehensive treatise on reaction mechanisms of organic conpounds in strong acid media (Liler 1971). This literature supported protonation as the controlling factor in the offectiveness of acids to selectively dissolve (extract) the organics from a matrix of organic and inerganic compounds. The literature also indicated that acids with high protonating ability are the most effective in dissolving organic base.

Much of the reported work has centered on the specific study of acid-catalyzed reactions. In those studies sulfuric acid/water aixtures were used because of their high degree of self-protonation. Dther acid solvents that have a self-protonating ability siailar to that of sulfuric acid are the mixturas of hydrogen fluoride/boron trifluoride and fluorosulfuric acid/antimony pentafluoride. Strong acids such as nitric acid and hydrobromic acid, and superacids such as perchloric acid would also be expected to have protonating abilities sinilar to those of sulfuric acid (Liler 1971). Sulfuric acid was selected as the solvent for this study because it has a high autoprotalys is constant.

\section{Eatabl ishing Reasonable Operating Conditions}

A series of bench-scale batch experiments were conducted with sulfuric acid to establish 1) reaction tine and optimun acid strength and 2) reactant ratios. The results of the experimental progran, discussed below, were used to establish practical (prelininary) processing conditions for an economic analysis of the industrial-scale sludge-to-solid fuel process shown in Figure 7.1 .

The tine required for the maximun extraction of the soluble fraction of the dry sludge and the ultinate product yield and quality vary with acid strength, teaperature, and the degree of agitation (mixing). The criteria for the optimu strength of the acid are deterained based on considerations of acid effectiveness for diseolving and reconstituting organics. Because acid strengths of less than 20 Normality (N) were ineffective, acid strengths of only $38,27.5$ and $20 \mathrm{~N}$ are reported in this study. Figure 7.2 shows the dissolution of total solids for the three acid strengths as a function of tiae at roon temperature. For all experiaents the acid-to-dry sludge ratio was held constant at $26 \mathrm{ml} / \mathrm{g}$.

The data suggest that maxinum dissolution of sludge is accomplished at about 24 hours for 27.5 and $36 \mathrm{~N}$ acid strengths. Although the dissolution increases with time for $20 \mathrm{~N}$ acid strength, other experiments show that the final product recovery is poor.

To exanine the effect of varying the reactant ratio on the percentage of dry sludge dissolved, various volunes of $27.5 \mathrm{~N} \mathrm{H}_{2} \mathrm{SO}_{4}$ were used for a fixed weight of dry sludge $(3 \mathrm{~g})$. Three local maxima in "the percentage of sludge dissolved as a function of reactant ratios' wore observed. The maxima occurred near ratios of 20, 40, and $85 \mathrm{ml}$ of $27.5 \mathrm{~N} \mathrm{H}_{2} \mathrm{SO}_{4} / 9$ of dry sludge. This pattern is sinilar to that observed by Senftle et al. (a) and is expected to vary with changes in tenperature and acid strength.

Deternining Product Recovery and Composition

The anount of solid fuel product and the percentage of organics in the product recovered fron the sulfuric acid solution were studied as a function of reaction time for different strengths of the dissolving acid solvent and are shown in Table 7.1. The aaxiaum recovery of the solid product ranges from about 20x to 25x using $38 \mathrm{~N} \mathrm{H}_{2} \mathrm{SO}_{4}$. This recovery is a function of the dilution factor and the temperature. (a) In a siailar study with $\mathrm{H}_{2} \mathrm{SO}_{4}$, $\mathrm{product}^{2}$ recovery as high as $35 x$ was obtained, with over $99 x$ of the product being organic aaterial. (a) In this study the

(a) Senftle, F., et al. 1988. 'Low-Ash Solid Fuel Via Acid Extraction fron Sowage Sludge.' U.S. Geological Survey, Conf idential Report. 


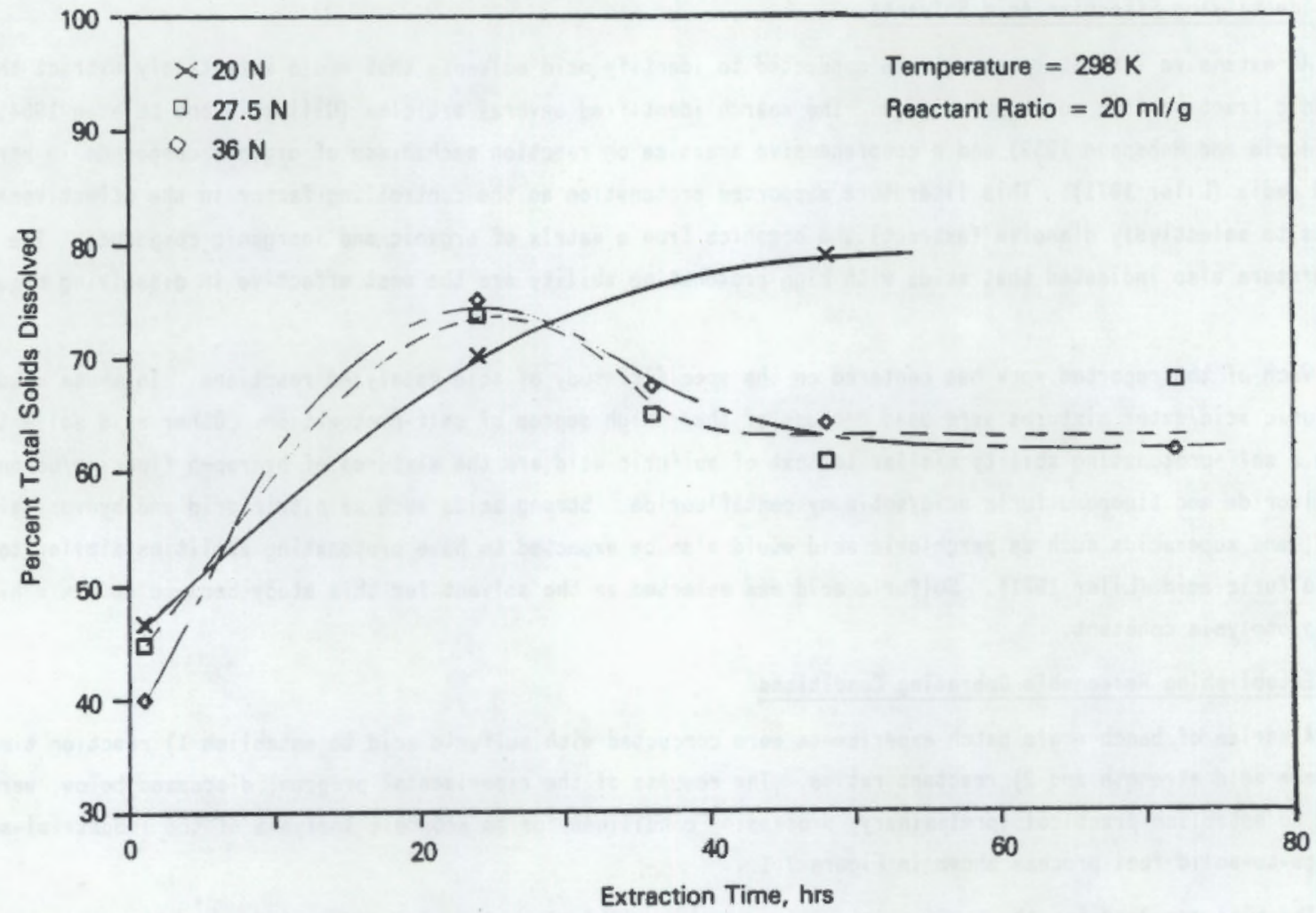

FICURE 7.2. Dissolution of Total Solids for the Three Acid Strengths as a Function of Time at Room Temperature

final product is also rich in organies (greater than $90 \%$ in all cases). Results of $C, O, H$, and $N$ analyses reported by Hackney $(a)$ in a prelininary study indicate that heating values of the final product (obtained from a similar process) vary froe $31 \times 10^{6} \mathrm{~J} / \mathrm{kg}$ to $34 \times 10^{6} \mathrm{~J} / \mathrm{kg}$.

\section{Process Impediments}

Although the process for extracting organic material fron the municipal sludge has been technically demonatrated, two process impediments have been identified based on the results to date.

The first impediment is the relatively low yield of the process. As indicated by the experimental results, reconstitution of less than $25 \mathrm{X}$ of the original product was achieved after deprotonation. Although the reconstituted material was very low in ash content, it represented oniy $26 x$ to $36 x$ of the theoretically recoverable organics. The recovery appears to be limited by the thermodynanics of the process. The composition of the sludge needs to be analyzed to determine if the undissolved materials are of the saturated hydrocarbon type, in which case, a multistage acid extraction systen aight be applicable, or whether adjustment of experinental conditions (e.g., temperature, type of solvent) night enhance the dissolution and reconstitution of the organic fraction.

The second impediment is the need to develop an acid recovery system and a way to recover and recycle any other additives used in the protonation or deprotonation steps. Concentrated sulfuric acid has been extensively used as a catalyst and as a reaction modiun for fertilizer production, pignent and paint preparation, etc. Acid

(a) Hackney, P. 1988. 'Low-Ash, Low-Sulfur Fuel Via Sulfuric Acid Extraction of the Organic Matter in Sewage Sludge." ME Thesis, Howard University, Mashington, D.C. 
TAQLE 7.1. Solid Fuel Product After Deprotonation(a)

\begin{tabular}{|c|c|c|c|c|}
\hline $\begin{array}{l}\text { Dissolving Acid } \\
\text { Strength, Normality }\end{array}$ & $\begin{array}{l}\text { Protonation } \\
\text { Reaction } \\
\text { Tine, Hours } \\
\end{array}$ & $\begin{array}{c}\text { Solids (b) } \\
\text { Recovered } \\
\end{array}$ & $\begin{array}{c}\text { Xrganics } \\
\text { Recovered } \\
\end{array}$ & $\begin{array}{l}\text { Organics } \\
\text { In Recovered } \\
\text { Sol ids } \\
\end{array}$ \\
\hline & 1 & 5.42 & 8.92 & 95.8 \\
\hline & 24 & 11.60 & 14.33 & 97.8 \\
\hline \multicolumn{5}{|l|}{27.5} \\
\hline & 36 & 12.88 & 16.58 & 96.4 \\
\hline & 48 & 14.94 & 19.43 & 97.5 \\
\hline & 1 & 7.99 & 16.43 & 97.8 \\
\hline & 24 & 18.59 & 24.29 & 98.6 \\
\hline \multicolumn{5}{|l|}{36} \\
\hline & 36 & 18.81 & 24.43 & 97.4 \\
\hline & 48 & 22.79 & 29.71 & 97.1 \\
\hline & 1 & 3.43 & 4.18 & 91.4 \\
\hline \multirow[t]{2}{*}{26} & 24 & 9.40 & 11.97 & 95.5 \\
\hline & 48 & 10.44 & 12.68 & 96.93 \\
\hline
\end{tabular}

(a) Reactant Ratio $=26 \mathrm{al}$ acid/gn of dry sludge. Deprotonation Dilution Factor $=$ 900 al $\mathrm{H}_{2} \mathrm{O} / 60$ al acid solution.

(b) Initial weight of dry sludge $=3.0$ grans.

(c) Initial weight of organics in dry sludge $=2.25$ grans.

recovery systens for these processes have been identified (Coers 1969; Unstead 1973; Peterson 1975). Therefore, applying the existing technology ay help remove this inpedinent.

\subsubsection{Econoaic Analysis}

One of the most important criteria for detarmining the viability of a new technology is its ability to be econonically competitive. To determine the concept's viability, the results of the concept's experimental progran were combined with reported literature results and engineering judgaent to formulate a prelininary cost estinate for conparison with other technologies.

Three significant deviations from the experinental progran results were assumed for the cost analysis:

1. The ratio of acid to dry sludge solid was established as $10 \mathrm{al}$ of acid per gran of dry solid. This ratio was selected because operation at the experimentally determined local maxima provides only marginal increase in sludge dissolved at disproportionately higher costs. (A sensitivity analysis indicated that the overall costs were wost sensitive to acid costs.)

2. The final acid normality was based upon the acid to dry solid ratio mentioned above, rather than the optiaum acid strength as suggested fron the experimental results.

3. An efficient industrial, nultistage wixer was assuned to be ablo to achieve the sane results during the protonation reaction in 38 minutes as the laboratory-scale wixer achioved in 24 hours. 
Other assumptions aade to facilitate the cost estinate are listed below (Peters and Timmerhaus 1980; Vernick and Walker 1980; U.S. Environmental Protection Agency (EPA) 1985):

- sludge production rate - $0.26 \mathrm{lb} / \mathrm{cap}$ ita/day

- foed sludge character - anaerobically digested at $20 x$ solids

- protonation reactor - $35 \%$ of solids dissolved and density of reactants same as $\mathrm{H}_{2} \mathrm{SO}_{4}$

- deprotonation reactor - 95\% of dissolved solids precipitated

- settling tank - negligible suspended solids in overflow and 4\% suspended solids in underflow

- centrifuge(s) - negligible suspended solids in supernatant and $14 \%$ suspended solids in flake

- acid recovery and protection systems - 35\% of capital and 20\% of the operating and aaintenance cost of plant

- acid and residue disposal costs - equal to value of motals/minerals recovered fron residue

- plant lifo - 20 years

- interest rate - 10x

- process water - no cost

- depreciation - not considered.

Table 7.2 presents the production costs on a dry-notric-ton basis as a function of population and efficiency of the acid recovery systen. The efficiency of the acid recovery system impacts the costa very dranatically. A $5 x$ drop in the officiency of the systen can increase costs by $15 \%(100,600$ population) to $64 \%$ (5 aillion population). For a $95 x$ acid recovery and for populations greater than 1 willion, the estimated cost is comparable to reported costs (EPA 1984) for land application (\$195), incineration (\$144), and conposting (\$161) (a) on a drymetric-ton basis.

The costs presented in Table 7.2 do not include the negative cost of sludge, i.e. the anount municipalities are paying for sludge disposal. Including this cost, which varies with the technique and the quantity of sludge disposed, would provide an even more positive comparison of this process to the conventional disposal techniques mentioned above. Unlike the competing technologies, discussed in the next section, the end product of the proposed process is a solid fuel, and the process has the potential to recover other ateriais from the sludge.

\subsubsection{Current State of the Art and Compoting Technologies}

The following sections discuss the methods currently being used to reuse or dispose of wastewater sludge and competing technologies being investigated.

\section{Current State of the Art}

Currently, five methods are videly used to reuse or dispose of wastewater sludge: land application, land filling, distribution and marketing, incineration, and ocean disposal (EPA 1984). The selection and implenentation of a particular disposal technique depend on many factors, including the source and quantity of wastewater sludge, geographic location of the conmunity, hydrogeology of the region, land use, econonics, public acceptance, and regulatory framework (EPA 1984). More often, a given aunicipality may have to use more than one technique to dispose of its sludge. Each disposal method is briofly described below.

Land application is defined as the spreading of sludge on or just below the surface of the land, whereas, land filling is the burying of sludge beneath a soil cover in a specially designated area. Currently, about $25 \%$ of the municipal wastewater sludge produced in the United States is disposed of by land application. A major impediment to future expansion of this option in urban areas will be the availability of land at a reasonable cost

Distribution and marketing of sludge products are fast growing as an option for managing sludge. This option is based on the soil conditioning and fertilizing values of sludge, and is priarily carried out by aedium- and

(a) Based on private communication in February 1988 with Mr. Francis Riddle, Water and Sewer Utility Administration, Department of Public Works, Washington, D.C. 
TABLE 7.2. Production Costs (\$/dry metric ton) for a Sludge-To-Sol id Fuel Processing
Plant As a Function of Population Size and Percentage of Acid Recovery

\begin{tabular}{|c|c|c|c|c|c|}
\hline \multirow{2}{*}{$\begin{array}{c}\text { Population } \\
\text { Served }\end{array}$} & \multicolumn{5}{|c|}{ Acid Rēcovery } \\
\hline & 95 & 96 & 85 & 80 & 75 \\
\hline 160,060 & $47 \sigma^{(b)}$ & 541 & 611 & 682 & 753 \\
\hline 260,660 & 373 & 444 & 515 & 586 & 657 \\
\hline 360,000 & 324 & 399 & 470 & 541 & 611 \\
\hline 460,860 & 360 & 370 & 442 & 513 & 583 \\
\hline 500,060 & $288^{(b)}$ & 288 & 358 & 421 & 492 \\
\hline 608,600 & 198 & 269 & 339 & 410 & 481 \\
\hline 796,600 & 191 & 282 & 333 & 484 & 475 \\
\hline $86 \sigma, 096$ & 185 & 255 & 328 & 397 & 467 \\
\hline 996,690 & 180 & 251 & 322 & 393 & 463 \\
\hline $1,000,000$ & $151^{(b)}$ & 221 & 292 & 363 & 434 \\
\hline $2,606,060$ & 131 & 202 & 273 & 344 & 415 \\
\hline $3,068,000$ & 122 & 193 & 264 & 335 & 466 \\
\hline $4,6 \sigma 6,6 \sigma 0$ & 117 & 187 & 258 & 329 & 496 \\
\hline $5,600,006$ & 112 & 184 & 254 & 325 & 370 \\
\hline
\end{tabular}

(a) Does not include the costs of sludge treatment prior to final use or disposal; the costs are per dry metric ton of raw material processed in December 1987 dollars.

(b) These values were calculated. All other capital costs were obtained by scaling the calculated values according to the following:

Capital and 0uy Costs (excluding acid) of $b=$ (costs for a) $X$ (population of b population of a) ${ }^{6}$. Acid costs were calculated in all cases.

and large-size municipalities. The coat of that option, however, way be relatively high compared with that of direct land application (EPA 1984).

Incineration is the burning of volatile eaterials in sludge solids in the presence of oxygen. This technique offers significant advantages compared with the other sludge disposal techniques because it reduces the sludge to a compact residue ash consisting of about $20 \mathrm{x}$ of the original volune of the aludge solid. Incineration also elininates some potential environmental problens by conpletely destroying pathogens and reducing many organic chemicals. However, it is a very costly technique that is only affordable for large municipalities.

Ocean disposal, although still practiced by about $4 X$ of the municipalities in the United States, is presently considered an unacceptable disposal option because of long-term environaental impacts.

\section{Conpeting Technologies}

Using sewage sludge to produce fuel oil and synthetic asphalt by direct theraochenical reactions is currently being investigated and has net with some success. Bayer and Kutubuddin (1982) have recently developed a technique to obtain oil fron sewage sludge by heating the dry sludge to $39 \sigma^{\circ} \mathrm{C}$ to $35 \sigma^{\circ} \mathrm{C}$ in an oxygen-free environment for about 30 minutes. The oil product has a heat content of 37 to $42 \mathrm{MJ} / \mathrm{kg}$ (the heat content of coal ranges from 21 to $34 \mathrm{~mJ} / \mathrm{kg}$ ).

Bridle and Campbell (1993) have repeated Bayer's and Kutubuddin's procedure using Canadian sludges and conf irm the formation of a straight chain hydrocarbon oil having a high heating value and a relatively low ash content. 
On a dry-woight basis, sewage sludge contains $36 \mathrm{X}$ ash. By converting the sludge to an oil, Bayer and Kutubuddin (1982) have been able to separate the ash, which remains in the residual sludge, from the oil to produce a lowash fuel oil with a high heating value.

Molton and Fassbender (1986) and Molton, Fassbender and Brown (1988) have demonstrated the feasibility of a continuous unit for converting primary sewage sludge to a burnable oil product. In a sludge-to-oil-reactor systen (STORS), they report a $73 x$ energy recovery in burnable products. An econonic analysis was conducted for cities with populations of $10,000,100,000$ and 1 million, and the disposal costs per ton of sludge were calculated to be S681, $\$ 114$ and $\$ 45$ (1983 dollars), respectively. These estinates were reported to be conservative and indicate that STORS has the potential for competing with incineration.

\subsubsection{Potential Markets for the Concept}

Sludge-to-solid fuel conversion, as an alternative sludge disposal technique, generates a high-grade, low-ashcontent fuel and a residue containing a variety of usoful motals. Because of this, any significant market analysis of this technology should address the following issues:

- sludge-to-solid fuel conversion as an alternative source of renewable energy

- fuel fron municipal sludge as an alternative technique for sludge disposal

- inorganic residue fron sludge-to-solid fuel conversion as source of valuable metals.

In Section 7.1.3, it was established that production costs of the sludge-to-solid-fuel process were lower than those of sludge incineration for large municipalities, if $95 \%$ of the spent acid could be recovered and recycled. A survey of 1611 treatment plants that generate $36 \%$ of the U.S. municipal wastewater sludge has shown that $32 \%$ of large treataent plants (greater than 10 MGD) use incineration before sludge disposal (EPA 1984). This suggests that a large market exists for new and cheaper sludge disposal techniques.

Although plants that convert sludge to solid fuel are not conpetitive as sources of cheap energy, the highgrade fuel they produce could be marketed without major difficulty. Also, the concentrations and types of metals in inorganic residue from such plants would depend primarily on the type and anount of industrial waste that is discharged into the municipal wastewater treatment systen. The sludge inorganic residue could contain a diversity of metals (cadniun, chroniun, copper, tin, zinc, titaniun, silver, gold), which nay have econonic potential.

\subsection{FUTURE CONCEPT DEVEOPPMENT}

This prelininary evaluation (Phase I) has determined the technical feasibility and the limits of the protonation and deprotonation steps of the proposed process. The assessment showed that the process can be economically feasible under certain conditions. The objectives of Phase II are to remove design uncertainties, to verify assumptions made for the prelininary econonic assessment, and to optinize product recovery. The results of Phase II will form the basis for a pilot scale (denonstration) unit (Phase III). This denonstration unit will be operated on a continuous or seni-continuous basis to verify technically and econonically the concept and design developed in Phase II.

The specific tasks to be conducted under Phase II are briefly described below.

Product Yield Improvenent - The product yield was quite low in our experinents, with less than 25\% of the original dry sludge being reconstituted after deprotonation. Although the reconstituted material was very low in ash content, it represented only $20 x$ to $36 x$ of the total recoverable organics. Deternining the organic components in sludge will provide information about the types of acids and the design of the protonation reactor needed to inprove the product yield. High protonating acid nixtures, acid/additive nixtures, and superacids vill be investigated.

Selection of an Acid Recovery System - The work perforned in this Phase I study identified several acid recovery systens that appear to have applicability in the excess acid extraction process (Goers 1969; Unstead 1973; Peterson 1975). A paper study of the candidate acid recovery system will be conducted to include prelininary cost estimates, 
accessibility to technology (i.e., patent-right protection), and generation of additional waste streans. The most prowising acid recovery system will be tested experientally to collect thermodynamic and kinetic data required for conaercial scaleup and detailed cost estinates.

Residue Treatment/Resource Recovery - The present work has indicated that approxinately $40 \pi$ of the solids in wastewater sludge will not dissolve under excess acid conditions in a connercially feasible time. This material, however, contains valuable winerals/aetals in concentrations that may perait their econonic recovery. This task will determine the technical feasibility of recovering these materials and the econonics of using the residue (with and without mineral recovery) as a road/construction material, soil amendment, ete. The results of this task will impact the overall detailed econonic assessment.

Optimization of Operating Conditions - Teaperature, acid normality, and aixing patterns may be the major parameters affecting the protonation/ dissolution process. Sone attempt was made to optiaize the normality for sulfuric acid in this study. Further experinents vill be conducted using the "best candidate acid/additive for product yield to deteraine optinum operating conditions. This information will provide a basis for a detailed process mass and energy balance. This data will later be used for a scaleup design of pilot and commercial units and for the overall econosic analysis.

Detailed Econonic Analysis - The economic assessment conducted in Phase I was based on generalized cost fact sheets. A detailed cost estinate based on properly sized reactors, pumps, pipes, etc., and actual costs of operation, maintenance, and supplies will be caleulated in this task. Total costs will be conputed for multiple population levels on a basis of dry ton of sludge processed. This vill facilitate a more accurate comparison of process costs to current reuse and disposal alternatives for sludge, such as conposting, land disposal, and incineration.

\subsection{REFERENCES}

Bayer, E., and A. Kutubuddin. 1982. 'Low Temperature Conversion of Sludge and taste to Oil." Proc. Int'I. Recyel. Recover Energy Uatter. Residues Iaste. ed. Thone-Kozniensky, J. E. Karl, Freitag-Verlag UaweTttech, Berlin, Gerany.

Bridle, T., and H. W. Campbell. 1983. 'Fuel Production Fron Sewage Sludge.' Proc. West Cand. Water Sewage Conf. Canada.

Donovan, J., et al. 1981. 'Physical and Cheaical Characteristics of Sewage Sludge." EPA Report 660/S2-81-242, Municipal Evvironaental Regeareh Lab., Cincinnati, Ohio.

Gillespie, R. J., and J. A. Loisten. 1954. 'The Behavior of Organie Conpounds in Sulfuric Acid." Quarterly Reviews, 40-68, Cheaical Society, London, England.

Gillespie, R. J., and E. A. Robenson. 1959. 'The Sulfuric Acid Solvent Systen." Advances in Inerganie Chenistry and Radiochenistry. Acadea ic Press, Men York.

Coers, W. E. 1969. "Purification et Concentration de I'Acide Sulfurique Contaninee par des Hydrocarbures." Freneh Patent $\mid 1,585,821$.

Liler, $M$. 1971. Reaction Mechanisns in Sulfuric Acid and Other Strong Acid Solutions. Aeadenic Press, London, England.

Molton, P., and A. Fassbender. 1983. 'Battelle-Northwest Sewage to Fuel Oil Conversion." U.S. Environmental Protection Agency, International Conf. Therwal Conversion of Municipal Envir. Res. Lab., Cineinnati, Ohio.

Molton, P. A. Fassbender and M. Brown. 1988. 'STORS: Battolle Northwost's Sludge to Oil Reactor Systen.' In Proceedings of the National Conference on Municipal Treataent Plant Sludge Management.

Poters, M. S., and K. D. Timerhaus. 1986. Plant Design and Economies for Chemical Engineers. MeGraw-Hill Book Company, New York.

Peterson, J. C. 1975. 'Apparatus for Recovering Sulfuric Acid and Ferrous Sulfate Crystals Fron Spent Pickle Solution." U.S. Patent $\$ 3,996,955$. 
Unstead, C. H. 1973. 'Evaporative Sulfuric Acid Recovery Fron Sulfuric Acids Containing Sulfate,' U.S. Patent \$3,713,786.

U.S. Environaental Protection Agency (EPA). 1984. Technology Transfer: Environmental Regulations and Technology.Use and Disposal of Municipal Wastewater Sludge. ERA 625/10-84-663-1984, Cincinnati, Ohio.

U.S. Environmental Protection Agency (EPA) 1985. Technology Transfer: Handbook Eatimating Sludge Manageaent Costs. EA 625/6-85-610-1985, Cincinnati, Ohio.

Vernick, A. S., and C. E. Walker. 1985. Handbook of Vaatewater Treataent Processes. Pollution Engineering and Technology. 19 tercell Dekker, Inc., Mei York. 
PROCESS EQUIPNENT

• 


\title{
8.0 DEVEOPMENT OF AN EEECTROSTATIC AGCLOMERATOR
}

\author{
Dr. V. J. Hruby
}

J. Bussok Co., Ine.

ABSTRACT

The objective of this work was to analytically investigate an electrostatic agglomerator that is designed to control the fine particles in industrial processes and pover plant flue gases. The operating principles of the agglomerator are simple. A flow of particle-laden gas is split into any branches. The branches are volunetrically equal, containing about the sane number of particles with about the same size distribution. The particles are charged positively in the half of the branches and negatively in the rest. Subsequently, the streans are reconbined in a manner that brings the oppositely charged particles into proxiuity. The sall distances between the negatively and positively charged particles result in significant Coulomb forces. Particles with the sane charge polarity repel each other, wile those with the opposite polarity attract each other, which leads to interparticle contact and aggloneration. The agglonerated particles are subsequently renoved from the gas strean by any conventional technique such as cyclones, filters, or an electrostatic precipitator (ESP).

Analyses have shown that the concept is feasible: particles can be charged and agglomerated, and the interparticle adhesion forces are strong enough to overcone collisional forces acting to break the agglomerates. The agglonerator can reduce both the energy consumption and the capital equipaent costs of exiating gas cleaning devices, and can reduce the costs of recycling particulate dust. The agglonerator can also reduce a respiratory health problen by increasing the efficiency of collecting subnicron particles in existing filtration devices.

Funding is now needed to further devolop the agglomerator concept. A two-phase program is recommended: Phase I would address near-term development and Phase II would address long-tern development. In Phase I, a bench scale test should be conducted to verify and refine the theoretical nodel. In Phase II, a full-scale or pilot denonstration should be conducted to obtain durability and aaintenance information, to optiaize the operational aspects of the equipment, and to dewonstrate the technology to industry. Throughout Phases I and II, a marketing effort is needed to identify the initial market niche for the agglomerator and to map out the most expedient path to comercialization.

\subsection{INTRODUCTION}

The enission of fine respirable particles or aerosols from coal-burning power plants represents a significant health and environmental risk. Fine respirable particles range in size from submicron to 10 microns in dianeter. Particles 1 micron or amailer are considered the most dangerous (Meyer and Edwards 1978). Their toxic effect is the result of one or nore of three nechanians: 1) the particles are intrinsically toxic because of their chemical akeup; 2) the particles can adsorb toxic substances on their surface; and 3) the particles interfore vith the aechanisas that norally clear the respiratory passages.

In addition to causing health risks, fine particulate enissions modify weather patterns because of their ability to absorb and scatter sunlight and to serve as condenaation or freezing nuclei. Therefore, a strong incentive exists to control and linit as auch as possible the particulate enissions from any source in general and fron pulverized coal-burning power plants in particular.

Pulverized coal is burned in flight, suspended in the hot oxidizing atmosphere of a large boiler. The pulverization, the node of conbustion, and the nature of the coal all help deternine the ash particle-size 
distribution. Figure 8.1 shows the particle-size distributions of particles enitted fron uncontrolled power plants. As the figure shows, as much as $50 x$ of the mass of all emitted particles can be belom 10 microns in diameter.

One posaible approach for controlling and liaiting particulate enissions is to remove the ash fron the coal before it is burned. Although coal beneficiation will reduce the coal's ash content, it is likely to result in the enittance of saller particies. Finer particles are produced because very fine coal pulverization is required to liberate and remove the small mineral and pyrite inclusions in the cosl. In the process of fine pulverization, the large mineral inclusions are pulverized as well. Because the officiency of most coal-cleaning processes decreases with decreasing particle size, coal beneficiation efforts can be expected to increase the fraction of

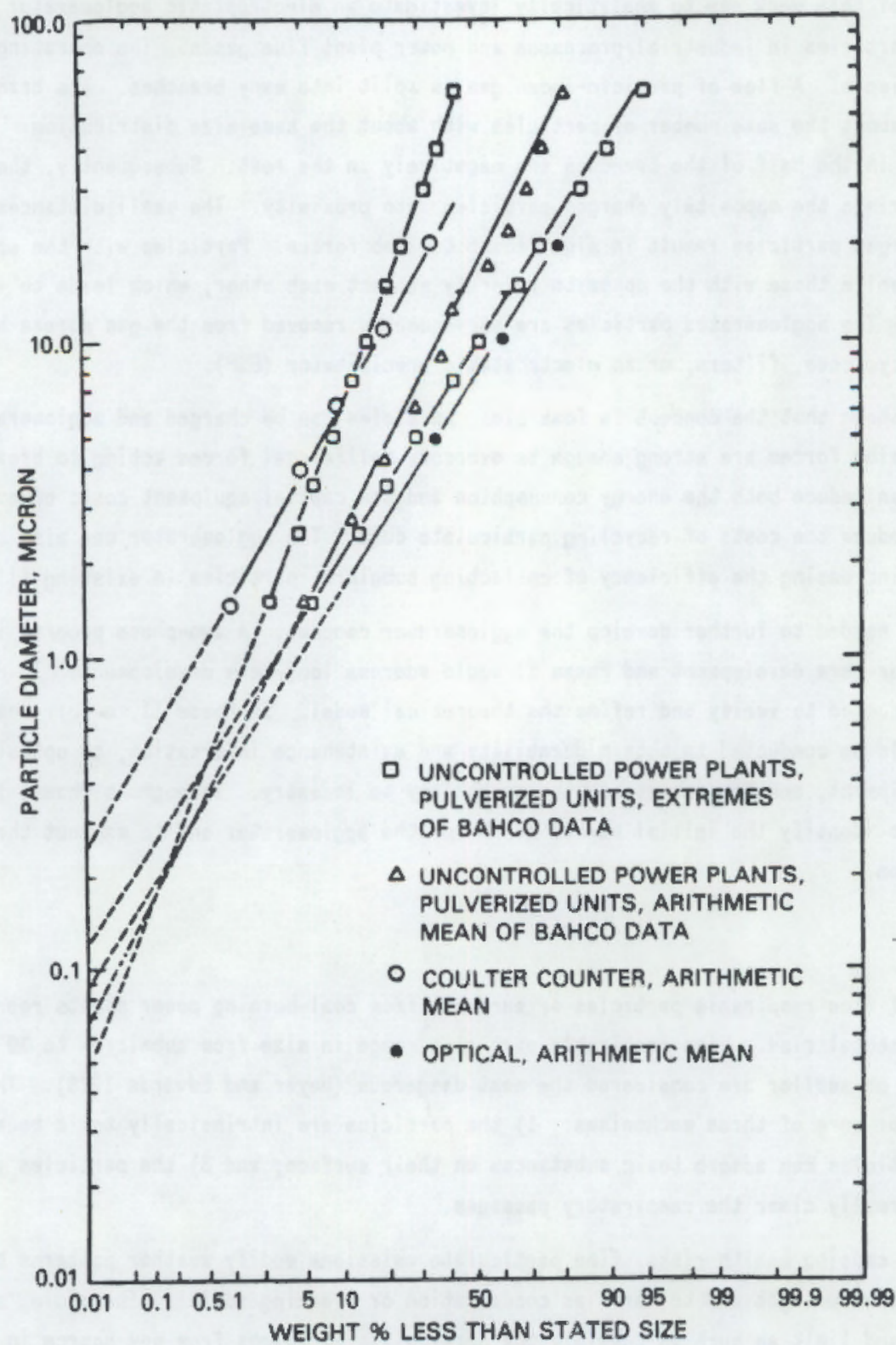

FICURE 8.1. Size Distributions of Particles Enitted fron Uncontrolled Power Plants (pulverized coal-fired boilers) (Shannon 1971) 
aicron-size particles in the boiler effluent. Therefore, flue-gas eleaning must be used to successfully reduce the particulate enissions when coal-cleaning processes are used before conbustion.

However, existing flue gas cleaning techniques and devices exhibit decreasing removal efficiency with decreasing particle size, as shown in Figure 8.2. In the figure, the efficiencies of all the conventional gas-cleaning devices are plotted against particle size (Moyer and Edwards 1978). The figure shows that for a particle diameter of 1 wicron or less, no device has a collection efficiency reaching $99 \mathrm{x}$ and that most conventional devices do not reach 99\% officiency even for particles with diameters of 5 wicrons. Therefore, to substantislly reduce the enissions of wicron or subuicron particles, the existing techniques need to be significantly improved or new approaches need to be devoloped.

\section{B.2 CONCEPT ASSESSMENT}

In the following sections, the electrostatic agglomerator concept is deseribed, and its benefits and technical feasibility are discussed. Also, impedinents to wide-scale use of the concept, state of the art of competing technologies, and its arket potential are addressed.

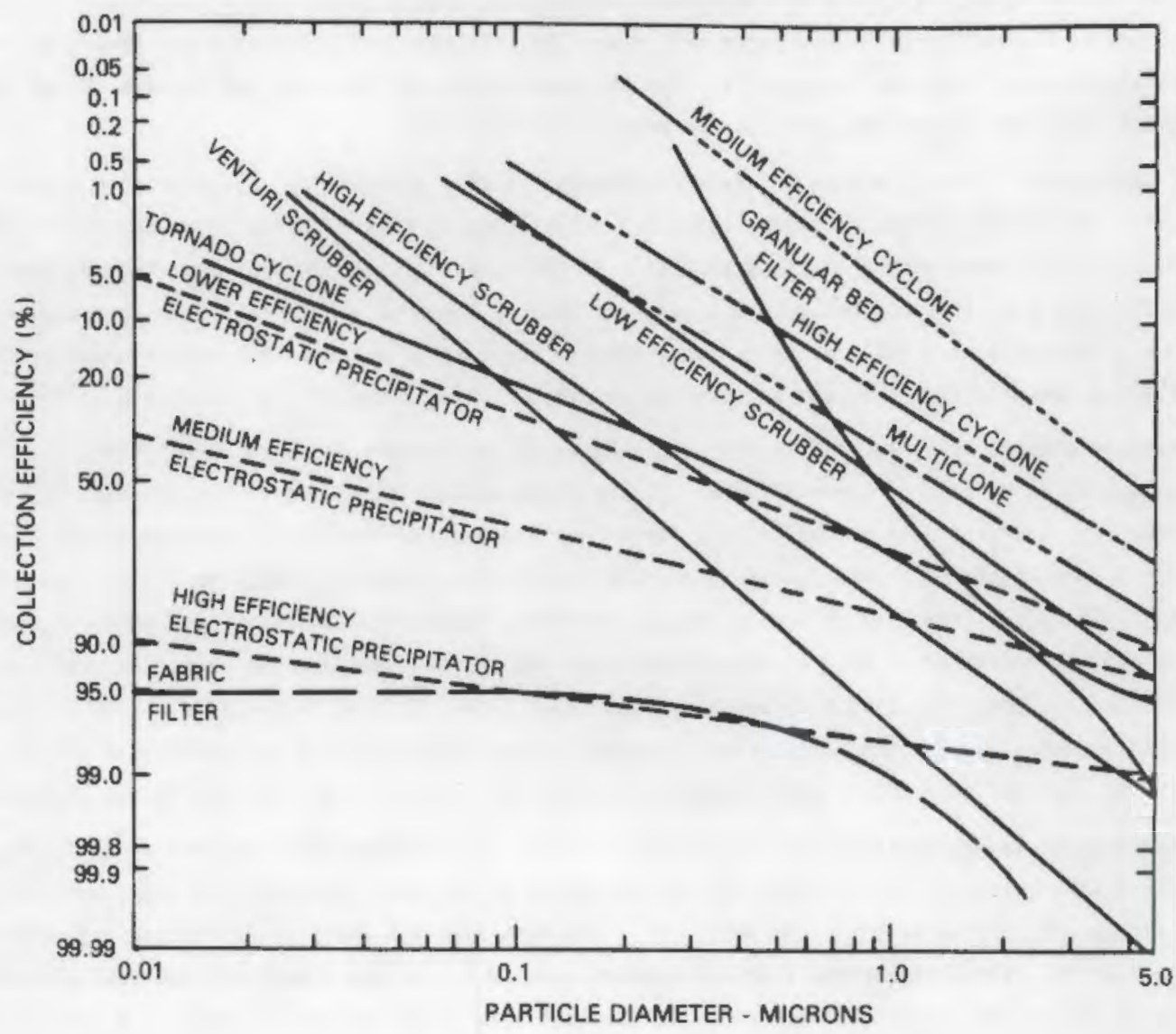

FIGURE 8.2. Extrapolated Collection Efficiencies as a Function of Particle Size for Various Filtration Devices (Moyer and Edwards 1979) 


\subsubsection{Description of the Electrostatic Agglomerator}

To significantly improve the efficiency of particulate collection, several approaches could be considered. Purely inertial separation techniques would be inappropriate for particulate sizes ranging from 0.5 to 10 microns. The following devices could be considered:

1. improved ESPs

2. natural or synthetic fabric filters

3. agglomeration of sall particles, followed by inertial or other conventional separation devices

4. innovative techniques that combine the features of the two or more devices listed above or that significantly improve then.

The proposed approach for the electrostatic agglomerator concept belongs in the third and fourth category. The operating principles are sinple. A strean of particle-laden gas is split into many approxinately equal streans, each containing roughly the same number of particles with the same particle size distribution. The particles are defined as solid or liquid droplets; they can be electrically conducted or insulating. The particles in half of the streans will be by some means charged positively and the other streans negatively charged. Then the streams will be recombined bringing the groups of oppositely charged particles into proximity, resulting in a significant mutually attractive Coulomb force. This force vill cause the particles to agglonerate and renain active until each agglomerate reaches electrical neutrality. The agglomerates can be renoved fron the gas strean using any of the conventional existing approaches, such as cyclones, filters or ESPs.

Several geometries of flow dividers and particle chargers appear suitable for electrostatic particle agglomeration. The concept chosen is shown Figure 8.3. The inconing flow is split into wany small electrically conductive channels that are square in cross-section. At the center of each channel is a high voltage corona wire. Each wire has a polarity opposite to its neighbor (oxcept those on a diagonal). In this manner the particles earerging from a channel with a positive wire, hence charged positively, are completely surrounded by negatively charged particles emerging fron the four surrounding channels. This is true for all channels in the watrix.

Each negative channel is surrounded on four sides by positive channels and vice versa. This facilitates rapid particle aggloneration because of three offects: 1) the fluid mechanical aixing of the streans, 2) interparticle Coulonb attraction/repulsion, and 3 ) the Couloab force from the applied electric field between the high voltage vires. As in a conventional ESP, the particles nigrate toward the collecting electrode (in our case the walls of the channels). Therefore, when the particlesenerge from their respective channels, high particle concentration will occur along the perineter of each channel relative to its center. Because all particles within the sane channel have the same polarity, they will nutually repel each other, forcing then into a stream of oppositely charged particles energing from the neighboring channels. Thus, both repulsive and attractive interparticle Coulonb force as well as the applied electric field force act in concert to create rapidly forming agglomerates.

The components of an agglomerator are shown in Figure 8.4. The agglomerator consists of an inlet plenum, a charger section that contains the channels, and an aggloneration section. Subsequently, agglonerates will be removed by a drop-out section or a cyclone separator. The particles are charged in the charging section and aigrate to the channel walls. When they energe from the adjacent channels, the oppositely charged particles combine because of the nutually attractive Coulonb forco. Finally, the agglomerated particles are inertially removed from the gas strean.

A typical application for an agglomerator could be a 250-ton-per-day container glass furnace vith particle laden gases flowing at 40,000 acfin. The agglomerator for this application would weigh about 12 tons and would be $7 \mathrm{ft} \times 7 \mathrm{ft} \times 2 \mathrm{ft}$. 


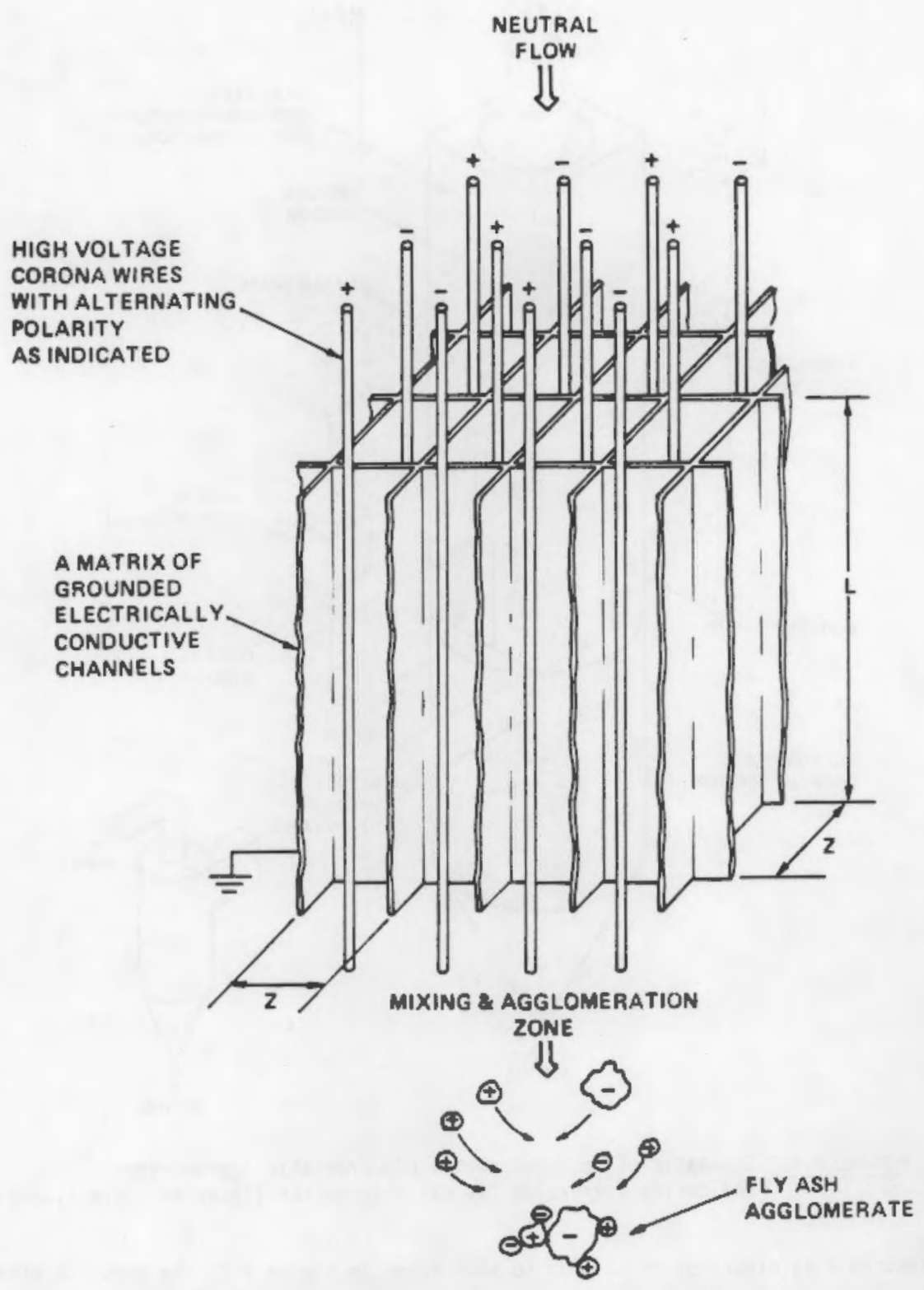

FIGURE B.3. The Proposed Electrostatic Particle Agglomerator Concept

\subsubsection{Benefits}

The agglonerator vill combine fine particles inte larger ones. In a gas strean with a single particle size uniformly distributed, the agglonerate size will be twice that of the entering particle. The agglomerate size will be larger because half the particles will be positively charged in the agglomerator and half negatively, and because each particle is likely to combine with another to becone electrically neutral. 


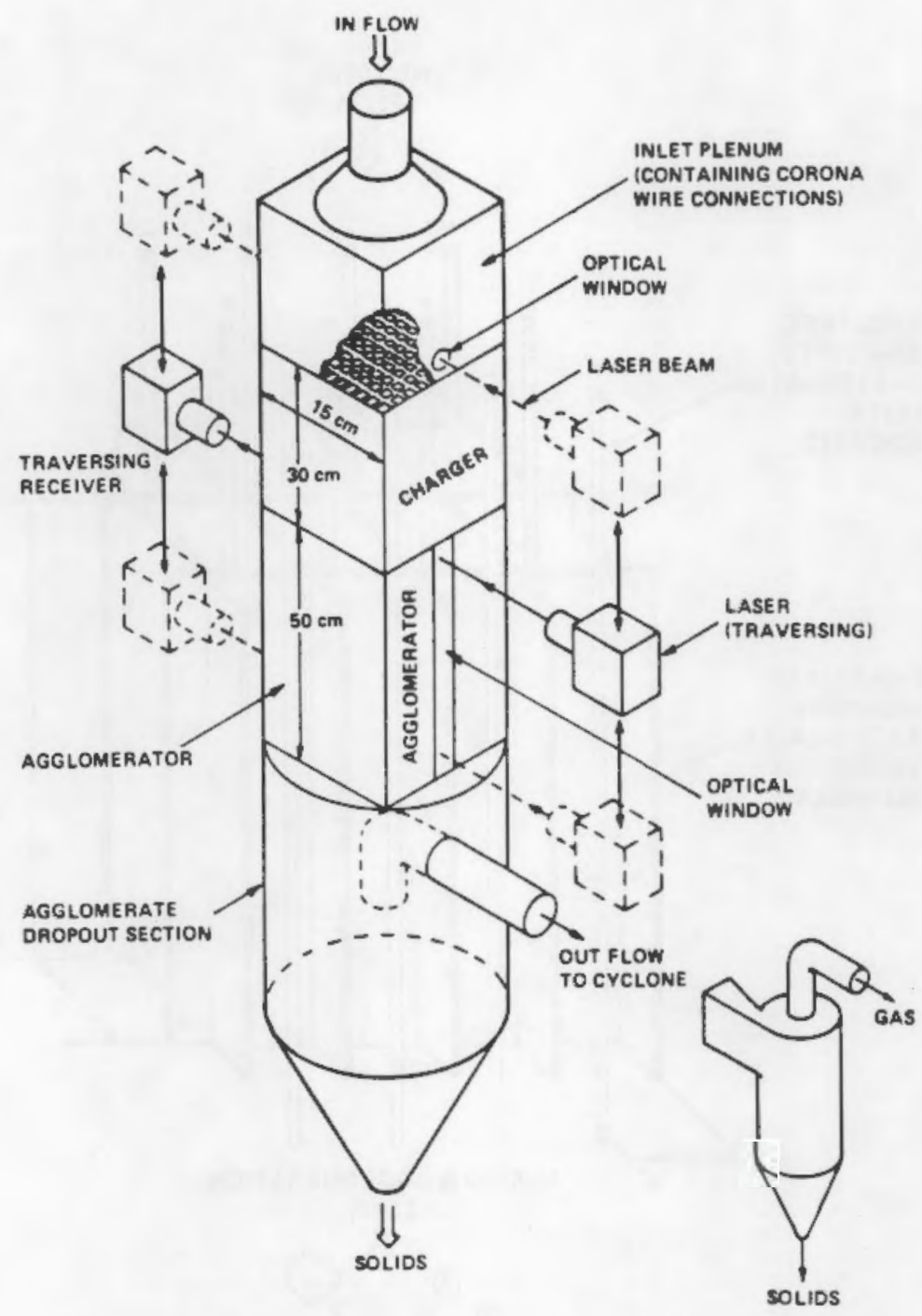

FIGURE 8.4. Scheatic of an Experinental Electrostatic Agglonerator Indicating Traversing Optical Diagnosties (laser particle sizer)

For a broad particle size distribution similar to that shown in Figure $\mathbf{0 . 1}$, the particle size change can be much more dramatic than the example described above. For example, in a gas strean with particles of two difforent sizes, a large particle can become olectrically neutral by capturing number of saller particles (N)

$$
N=\frac{r_{L}^{2}}{r_{S}^{2}}
$$

$$
\text { where } \begin{aligned}
r & =\text { radius } \\
& L=\text { large particle } \\
& S=\text { small particle }
\end{aligned}
$$

because the charge on a particle is proportional to its radius squared. A particle with a dianeter of 10 microns could capture and thus ol iminate 10,690 particles of 0.1 micron diameter before beconing olectrically neutral. 
For clarity, the above example was given for only two particle sizes. However, the offect is qualitatively the sane for realistic gas streams that have a large number of particle sizes. The resulting shift in the particle size distribution way allow the following benefits:

- reduced energy use and capital costs in flue gas clean-up equipaent

- reduced costs of recycling

- decreased health hazard from fine respirable particles.

Each of these benefits is discussed belor.

Reduced Energy Use and Capital Equipaent Costs

As Figure 8.2 shows, ESPs or fabric filters nust be used for particles below 5 microns. For a typical glass furnace, the installed costs of these devices range from $\$ 1$ million and $\mathbf{8 1 . 5}$ aillion and the operating costs from $\$ 150,900 /$ year to $\$ 250,608 /$ year.

The agglomerator's installed cost would be about \$206, 660, with operating and maintenance expenses at \$15, 600/year. A 200-m coal-fired power plant would require 8 such agglomeratora, for an installed cost of about

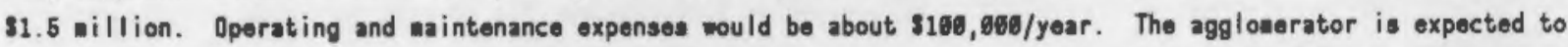
increase the particle size distribution to values larger than $\mathbf{5}$ microns, which would allon cyclones to be used. This would save about $\mathbf{3 1}$ willion on installed cost and most of the 8158,068 to 8250,960 on operating costs. The cost of the agglomerator would be low compared with the ESP because its size is estinated to be one-hundredth that of the ESP.

\section{Reduced Costs of Recycling}

In the steelaaking industry large amounts of particles are entrained in the furnace flue gas. In electric are furnaces 17 to $2 x$ of each charge is converted to dust (Horlitz and Baumann 1987). In the past this dust has been dumped, but now it is listed as a hazardous waste. If this dust could be recyeled, the hazardous waste disposal problen would be eliminated. The dust also has commercial value because of its alloy content. The agglomerater could reduce the cost of recycling this aterial by increasing the average particle size.

Decreased Health Hazard

As Figure 8.2 shows, the collection efficiency of subuicron particles is quite poor. For particles 1 aieron in dianeter or less, an ESP with average officiency, which is typical in the industry, will capture less than 9ax. Unfortunately, these particles create a significant health hazard because they can enter the respiratory system. The agglomerator will allow conventional filtration devices to remove a greater percentage of the fine respirable particles.

\section{B.2.3 Techñical Feasibility}

The technical feasibility of the agglomerator was analytically investigated by calculating the charge delivered to the particles, the forces pulling the particles togother, the trajectory and tine required for agglomeration, the interparticle adhesion forces, and the force necessary to pull apart agglonerated particles. These issues are addressed below in the order that a particle moves through the electrostatic agglonerator (i.e., charging, - lectrophoresis, adhesion, and agglomeration).

\section{Charge Delivery - Ion Bombardment and Diffusion}

The easiest wethod of charging gas-suspended particles is with a carona discharge. A corona can charge particles in one of two ways: ion bonbardaent and ion diffusion. Calculations show that for particles larger than 1 aicron ion bombardment is the dominant offect, and for subnicron particles ion diffusion dominates. 
For previously uncharged particles, Moore (1973) and Straus (1971) deterained that nearly 99x of the attainable charge is reached in the first millisecond. About $10 \mathrm{msec}$ of ion bombardment is needed for the particle to reach 99\% of the maxiaum charge. This analysis indicates that it is quite feasible to adequately charge the particles.

\section{Interparticle Forces, Trajectories, and Time to Agglonerate}

The interparticle forces are electrostatic in nature. Therefore, they are a function of the inverse of the interparticle distance raised to power of 2 (or 5 if polarization effects are conaidered). For a typical coalfired device, interparticle separation distance is calculated to be less than $1 / 2 \mathrm{~m}$. At this distance the najor - lectrostatic forces between two charged particles is the Coulomb force $\left(F_{c}\right)$. The force from polarization of the particles, which exists even if only one of the particles is charged, is two orders of magnitude lower.

In addition to the interparticle forces there are forces on each particle from the electric field between the high voltage negative and positive vires. For an electric field of $10^{5} \mathrm{~V} / \mathrm{m}$, the magnitude of the applied force $\left(F_{E}\right.$ on 16-wieron and 1-nicron particles is $8 \times 10^{-11} \mathrm{~N}$ and $8 \times 10^{-13} \mathrm{~N}$, respectively. The corresponding acceleration of 1-nicron particles is about 140 times that of the earth's gravity.

The particle trajectories were exanined to deteraine the time required for the two particles to come into contact fron the initial aximum separation distance. This exanination was done by obtaining an approxisate solution to differential equation of motion, including the inertial and aerodynanic forces. The resulting relative velocity of the two particles approaching each other is 5 to $6 \mathrm{co} / \mathrm{sec}$, resulting in closing tines of $6.01 \mathrm{sec}$ This is not a surprising result. Sieilar velocities are experienced in conventional electrostatic precipitators. However, the electrode separation, which is half the distance a particle uust travel to precipitate, can be as much as 3 orders of magnitude larger than the distance the particles must travel to agglomerate. This has obvious implications on the equipaent size and, hence, the cost. For many older coal-burning power plants, the question of size way be more impertant than cost because the plants do not have enough space to install additional largescale pollution control equipment.

\section{Interparticle Adhesion Forces and Collisional Effects}

When two oppositely charged dielectric particlea cone into contact, they adhere to each other because of the following forces:

1. interparticle Coulonb force

2. force due to polarization (dielectropheretic)

3. van der Waals force

4. surface tension/capillary force.

For aerosols the capillary force will be the doninant force. It ay also become iaportant for solid particles coated with moisture or condensing acids, which may occur under power plant exhaust conditions. It can be shown that for dry particles the van der Maals forces doninate the electrostatic forces even if the 'point of contact" - lectric field enhanceaent and, hence, Coulomb force enhancenent analyzed by Moslehi and Self (1984) is taken into account. Calculations show the van der Waals adhesion force is of the order $10^{-7}$ to $10^{-8}$ Nertons.

Having established that agglomeration of particles is feasible, the forces that may break the agglomerate apart must be exanined. The nost likely cause of agglonerate separation are nid-strean particle/agglomerate collisions. For example, in a systen of 3 particles, particle 1 , with a mass $n_{1}$, woves at a relative velocity $v_{1}$ toward an agglonerate of $m_{2}$ and $m_{3}$. Upon impact, the mass $m_{2}$ transfers nost of the $v_{1}$ monentun to $m_{3}$. We seek the relative velocity $v_{1}$ of mass $v_{1}$ that can inpart sufficient acceleration to $\boldsymbol{m}_{3}$ to cause its separation from $\boldsymbol{m}_{2}$. Assuming that particles 1 and 2 are 10 microns in dianeter and that particle 3 is a 1 eicron particle, the acceleration is

$$
d v_{3} / d t=2.5 \times 10^{6} v_{1}
$$


To overcone the van der Waals adhesion force $\left(10^{-7}\right.$ to $10^{-8}$ Newtons), the necessary acceleration of $m_{3}$ is about $8 \times 10^{6}$ to $10^{7} \mathrm{e} / \mathrm{sec}^{2}$. Fron the above equation, this yields relative volocity $\mathrm{va} / \mathrm{sec}$. It is highly unlikely that this relative interparticle velocity can be achieved in a viscous media such as air. Therefore, particle-toagglomerate collisions are not Iikely to overcome the van der Waals forces and break up the agglowerate.

\section{Sumnary}

The following conclusions can be drawn fron the above theoretical investigation:

- The particlea can be adequately charged quickly with an acceptable agglomerator size,

- The charged particles are accelerated towards one another at 5 to $6 \mathrm{ca} / \mathrm{sec}$, resulting in closing tines of 6.61 second.

- Van der Waals forces will adhere particles together.

- Collisional forces will not separate previously adhered particles.

\subsubsection{Impedinents to Wide-Scale Use}

While the agglomerator appears to offer considerable advantages, the technology needs to be developed and a full-scale denonstration is needed for industry acceptance. Specifically, the folloving needs to be done:

1. Snall-scale experinents nust be perforned to demonstrate the concept's feasibility.

2. Agglonerator operating conditions must be parametrically analyzed. These conditions include particle charging, forces pulling the particles together, the interparticle adhesion forces, and the force needed to pull apart the particles. The equations describing these physical phenonena have already been written, and some approxinate solutions have been obtained.

3. The agglomerator's energy consunption must be accurately deterained. This is influenced by particle loading and size distribution, the channel aspect ratio, whether staging is used, the agglomerator size, and the gas and particle akeup.

4. A subscale test in an industrial onvironment aust be conducted to demonstrate the technology to the end users. A technology demonstration that uses a slip strean of a typical, large piant would be ideal.

\subsubsection{State of the Art of Competing Technologies}

The proposed concept is unique and, as far as wo know, not studied in the context of the present application. However, wany studies have been conducted on the same principles of particle-to-particle attraction/repulsion in other applications. In some cases the objective is to avoid aggloneration and particle stringing (forming chains); in other cases, the objective is the opposite. For example, Nolny and Opalinsky (1983) added a saall proportion of fines ( 0.1 vol $\$$ ) to $1 \mathrm{~mm}$ polystyrene beads to neutralize the charge on the beads and to prevent their adhesion to the walls of a drying fluidizad bed. Thus, in this successful application their objective was the same as ours to agglowerate fines on larger particles.

One of the nost troublesome difficulties in electrostatic coal beneficiation is the suspected agglomeration of fine ash on oppositely charged coal particles. The proposed concept in part originated in my attenpts to prevent such aggloneration.

With the exception of the ESP, the conceptually nearest relative to the agglonerator is an electrof luidized bed (EB). Lahedi and Welcher (1976) proposed its use as a subwicron filtration device. In the EB, the large bed particles for the collection sites of the subnicron particles flowing through the bed. The inertial impaction filtration present in nonelectrified beds is enhanced and is dominated by the electrostatically induced filtration because of an imposed electric field across the fluidized bed. Experimental work confirned $99 x$ collection efficiency of submicron particles. 
An example where agglomeration or particulate chain formation is the objective are devices that use electrofluidized beds for momentum transfer, such as special clutches or brakes. Fundanental study of the momentum transfer was carried out by Dietz and Melcher (1978).

Particle/fly ash acoustic aggloweration research is being conducted at the Pennsylvania State University. However, current predictions show operating costs of this system to be as high as $8550,600 /$ year for a $250-\mathrm{Mil}$ power plant (Reethof 1985).

ESPs and baghouses can be used to remove fine particles. However, the capability of these devices in capturing the smallest particle dianeters is linited. A mediun-efficiency ESP has a 99 capture officiency vith particles sizes no saaller than 5 microns. Cyclones, while less expensive, have a $95 \%$ capture efficiency with particles no saaller than 40 aicrons. A fabric filter has an officiency in the high nineties down to a particle size of 1 to 2 nicrons. However, its capital and operating costs are high. Of course, it is possible to derate a given industrial process. This reduces particulate enission at all sizes but it also reduces production.

In the glass industry electrical boosting can be added to a furnace, thus allowing, for a given production level, less combustion gas flow and reduced particulate carryover. However, electrical boosting significantly increases the operating cost of a furnace, prinarily because of the high cost of electricity in most parts of the country.

\subsubsection{Market Potential}

The market potential for the agglomerator is quite large because many industrial processes have large amounts of particulate enissions. Table 8.1 lists several industrial sources (Shannon 1971). For example, in the steel industry alone, about 500 furnaces ranging in capacity fron 480 to 2400 tons per day could benef it from using the agglomerator. Likewise, in the glass industry about 250 furnaces ranging in capacity from 150 to 600 tons per day could benefit frow using the agglonerator.

\subsection{FUTURE CONCEPT DEVELOPMENT}

The next steps in the agglomerator's technical ovaluation are as follows:

- bench-scale testing to verify and refine the theoretical model

- systen study to deternine all of the components needed and their interrelationship and to identify the optinum configuration of the agglonerator and auxiliary conponents for various market niches.

TAQLE 8.1. Fine Particulate Eaissiong from Industrial Sources (less than 3 microns) ( $10^{3}$ tons/year)

\begin{tabular}{lll}
\multicolumn{1}{c}{ Industrial Source } & & Partic \\
Coal - Electrical Utility & & 976 \\
Iron and Steel & & 300 to \\
Pulp Mills & 319 \\
Cement & 177 \\
Carbon Black & 93 \\
Secondary Non Ferrous & 127 \\
Glass & $16(a)$ \\
Municipal Incinerators & 10
\end{tabular}

(a) Estimated by author. 
- subscale or pilot demonstration in an industrial or power plant onvironment to obtain durability and aaintenance information for optinizing the equipment's operational aapects (with end-user's participation) and to demonstrate the technology to industry

- market study to deteraine which niches are nost favorable for the agglomerator and business plan developnent to comercialize it.

A two-phase progran is recommended that will address all of the above issues.

\subsubsection{Phase I - Near-Tern Development}

A bench-scale experimental facility, as shown in Figure 8.5, will be constructed and operated. It consists of a Plexiglas (a) enclosure containing the inlet plenum (top), the charger section, channels, aggloneration section, and a cylindrical section that will be used as a particle drop-out chanber and a flow discharge plenun before the particles' entry into the indicated cyclone.

A laser particle sizer vill nonitor the particulate number density and their size distribution, traversing fron the charger inlet position to the agglonerator section exit. The working fluid will be roon temperature air provided by a centrifugal blower or wixture of $\mathrm{N}_{2}$ and $\mathrm{CO}_{2}$ stored in gas cylinders. The flow rate through the - lectrostatic agglomerator (noninally $50 \mathrm{cfm}$ ) vill be controlled by bloeding off the excess air provided by the oversized blower. The particles will be introduced into the main gas flow by a fluidized bed feeder. The particles $\approx \mathrm{ill}$ bo $\mathrm{SiB}_{2}$ and $\mathrm{Al}_{2} \mathrm{O}_{3}$ used in the optical grinding industry and conninuted fly ash purchased from a local pulverized coal-fired power piant.

After the flow passes through the agglomerater, it enters a conventional cyclone. The cyclone discharge will be sampled using a high-density filter to collect the particles and subsequentiy deternine the particulate size and nuaber density exiting the systes. Hovever, because the cyclone is not the subject of this study, the data of

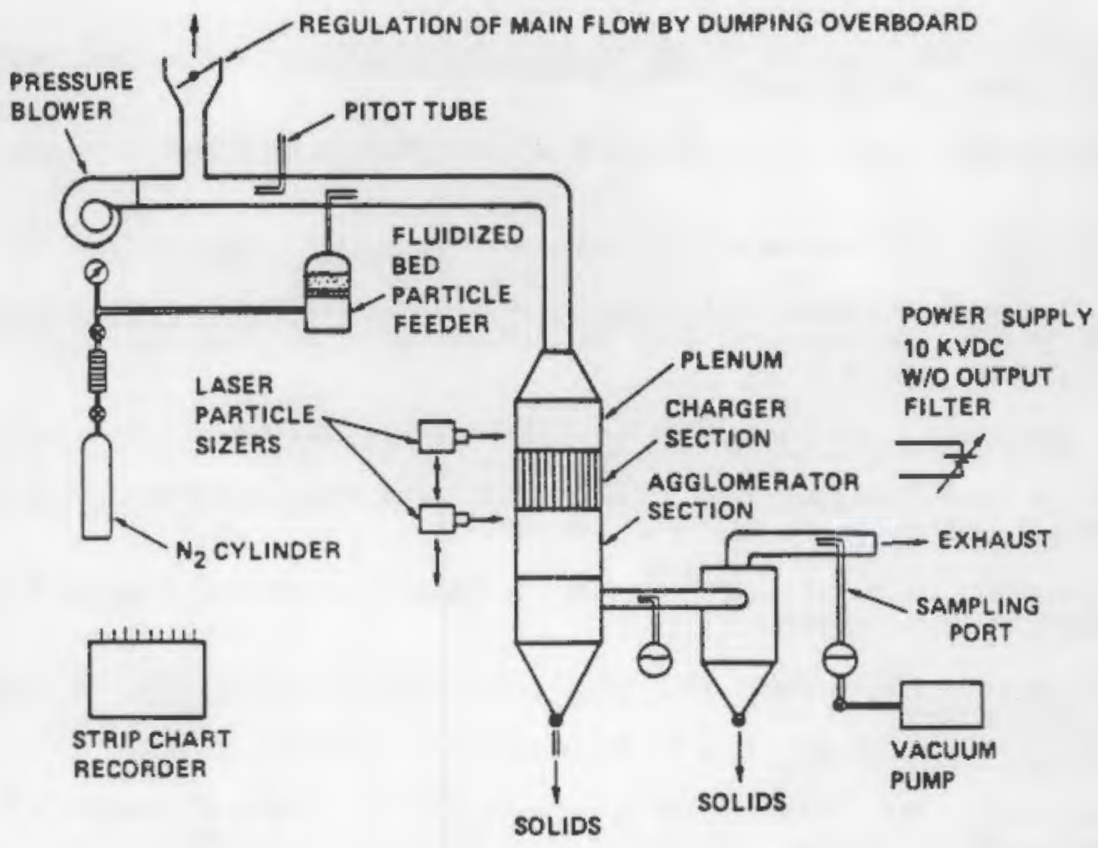

FICURE 8.5. Proposed Experimental Facility for Testing the Electrostatic Agglomerator

(a) A trademark of Rohn Haas, Philadelphia, Pennsylvania. 
primary importance nust cone fron the laser particle sizers. The lasers will deternine if the particles are agglonerating and how large the agglonerates are.

The results fron the bench-scale testing will be used in refining the conceptual design and designing the fullscale syaten. Also, in this phase the target industrial or power plant aarket vill be identified. The best market niche for the agglonerator vill be useful in deteraining host site candidates and the final design details for a full-scale denonstration.

Phase I vill also include a prelininary evaluation of the connercialization approach, and various warketing partner candidates will be identified. These candidates will probably be ESP or cyclone manufacturers vith close ties to the targeted arket niche. The narketing partners will be chosen in Phase I so that they can contribute their expertise in Phase II.

Consideration vill also be given to producing the agglomerator. If internal resources and company overall plans pernit, the Busek Co., Ine., may manufacture the agglomerator. Otherwise, a manufacturing partner will be sought.

\subsubsection{Phase II -- Long-Tern Development}

The full-scale desonstration of the agglonerator will be accomplished in Phase II. A host site vill be secured from the candidates identified in the previous phase. The agglomerator and auxiliary equipment will be designed and anufactured or purchased as necessary.

The equipment will be operated at the host site and data collected to document its perfornance. The facility will also be available for tours by prospective end users. Concurrent with the denonstration task, the final marketing approach vill be deterained and a business plan vritten.

\subsection{REEERENCES}

Dietz, P., and J. Wolcher. 1978. Momentum Transfor in Electrofluidized Bed. The Merican Institute of Chenical Engineers, Sunposiun Series, $74(175): 166-174$.

Herlitz, H. O., and P. Baunann. 1987. Hetal Recovery fron Oxidic Waste Using Plasma Tochnology." Industrial Heating.

Hasuda, S. 1981. "Industrial Applications of Electrostatics." Journal of Electrostatics. 16:1-15.

Noyer, J. P., and M. S. Edwards. Novenber 1978. A Survey of Processes for High Temperature-High Pressure Gas Purification. ORLL/Th-6178, Prepared by Oak Ridge National Laboratory, Oak Ridge, Tennessee, for the U.S. Departaent of Energy, lashington, D.C.

Moore, A. D. 1973. Electrostatic and Its Applications. Viley \& Sons, New York.

Moslehi, G. B., and S. A. Self. Nov./Dec. 1984. 'Electronechanics of Precipitated Particulate Layers.' IEFF Transactions on Industry Applications. Vol. IA-26. No. 6.

Reethof, G. 1985. 'Mcoustic Agglomeration of Power Plan Fly Ash for Environaental Clean-up." Penn State University, University Park, Pennsylvania.

Shannon, L. J., P. G. Goraan and M. Reichel. 1971. Particulate Pollutant Systen Study. Uidwest Research Instituto, Kanasa City, Miasouri.

Straus, 1. 1971. Air Póllution Control. Part I. Niley and Sons, Now York.

Wolny, A., and I. Opalinaki. 1983. Electric Charge Neutralization by Addition of Fines to a Fluidized Bed Composed of Coarse Dielectric Particles." Journal of Electrostatics. 14:279-289.

Zahedi, K., and J. Melcher. 1976. 'Electrofluidized Beds in the Filtration of a Subaicron Mrrosol." Journal of the Air Pollution Control Association. 


\subsection{LARGE-SCALE GENERATION OF MICROBUBBLEC TO IMPROVE FLOTATION PROCESSES ANO TO SAVE ENERGY}

Donald L. Micheisen, Willian Foreman, and David Michelsen

Virginia Tech

ABSTRACT

Low-cost efficient nethods of producing nicrobubble dispersions on a large scale need to be developed to take advantage of many potential industrial applications where nicrobubble dispersions could significantly reduce energy consumption and the cost of industrial separations processes. Colloidal gas aphrons (CGAs) are a stabilized form of microbubble dispersions that contain $50 \%$ to $70 \%$ of $5 \%+/-40$ aicron dianeter bubbles in water-based solutions. They have nany potential applications, such as enhancing bioreactions, fine particle flotation, in situ hazardous waste treataent, and even firefighting.

Laboratory-scale experiments on CGA applications have used spinning discs to produce nicrobubble dispersions in small quantities. However, the spinning disc method may have limited potential for economical scaleup. A packed column method has been demonstrated for producing larger quantities of CGAs. A spinning cylinder currently is being tested as an alternative aethod for economically producing large quantities of high-quality CGAs. Prelieinary results of bench-scale tests on the spinning cylinder indicate a considerable inprovenent in generating nicrobubbles with good stability and bubble size, winimum void air, and reasonable operating costs. A larger unit has been designed and is being built for testing in this project.

The firat objective of this work was to scale up, design, fabricate, and test a 36 to $50 \mathrm{gal} / \mathrm{min}$ spinning cylinder generator. The goal was to make the equipment available for conducting feasibility/economic field studies for several applications. The second objective was to test the existing pilot-scale generator using various spinning cylinder configurations to optinize the systen for maxinum flexibility.

\subsection{INTRODUCTION}

Foans generally fall into one of two classes: 'wet' and 'dry." In a wet foan the air content is low, 75x or less, which allows the bubbles to be far onough apart that none of then is distorted by another. As a result, the bubbles adopt a spherical shape in an attenpt to ainiaize their surface energy.

The traditional term for a wet foan is kugelschaun or spherical foan. The diameters of the bubbles of a kugelschaum are not limited to any particular size; hovever, there are sone differences between foans consisting of mostly tiny bubbles and foans consisting of nostly large bubbles. The greatest difference is in the tine the bubbles stay in suspension. As bubble size decreases, the force driving the bubbles to the surface (buoyancy force ainus drag force) also decreases, thus lengthening the amount of time it takes for the bubbles to rise to the surface. They reaain in suspension longer. Kugelschauns with bubble diameters less than 250 microns are termed nicrobubble foans and, because of their size, are more stable than the larger (up to several aillimoters) kuge ischauns.

Generating bubbles is not necessarily the precursor to foam generation. Bubbles, large or sall, can be generated and exist widely dispersed in a continuous medius. These formulations have very low concentrations of air and are usually transitory. Examples include bubbles foraed by electrolysis or dissolved air techniques (10\% air bubbles).

As bubble size is reduced to below 50 wicrons with fen greater than 100 microns, colloidal properties becone apparent such as the ability to reasin dispersed in liquid without significant coalescence. These 46x to 66x microbubble foans contain a dispersion of small stabilized air bubbles in an aqueous mediun. They have a viscosity of 10 centipoise (cp), redueing of course, to that of water as the quality (good stability and bubble 
size and minimun void air) approaches zero. First investigated by Sebba (1971) under the name of nicrofoans, their behavior was significantly different fron other foans; to prevent confusion the nane 'colloidal gas aphron" was introduced (Sebba and Barnett 1981).

The name 'aphron' comes from the Greek 'a I" poo", a foan, and has been coined to mean any fluid encapsulated in a thin aqueous shell, or, a true bubble. Like nicrobubble kugelschauns, CGass consist of gas spheres enclosed in a soap fila of dilute surfactant solution; the ajor difference in the two lies with the stabilized encapsulating soap shell characteristic of CCAs. CQh of practical interest typically contain 56x to $65 x$ air by voluas. As the concentration of air is increased above or below this range, this stabilized aicrobubble foan denonstrates reduced offectiveness in most applications.

Although Sebba (1981) lists the size range of CGs at 25 to 50 aicrons, samples taken by the inproved technique developed in this work indicate that the range is broader, 15 to 120 vicrons, with an average of $50.7 \pm$ 22.7 microns. Further technical aspects of CGA structure and properties are discussed in Sebba (1981) and in a recent book by Sebbe (1987).

\subsection{CONCEPT ASSESSMENT}

In the following sections, the proposed concept is described, and its potential energy savings, technical feasibility, impedinents to widespread use, and prior work and state of the art are discussed.

\subsubsection{Description of the Concept}

A large generator has been designed to produce CCAs at a rate of 30 to 50 gallons per ninute. The design is sinilar to the sall cylinder CGA generator shown on Figure 9.1. Details are not included because of patents currently being filed. The generator has been designed to operate at 100 psig and will have an all 364 stainless steel construction. The outer stainless steel 12 inch shell and inner spinning cylinder can be replaced with clear acrylate piping to reduce woight and potential balance problens, and to allow visual observation while it is operating near atmospheric pressure. At this time the eaterials have been received and fabrication is proceeding.

The design will allow a wide range of rotational speeds ranging frow 587 rpa to as high as 5286 rpa. Based on scaleup fron earlier testing using a smaller-diameter eylinder, $1250 \mathrm{rpm}$ should provide the same surface

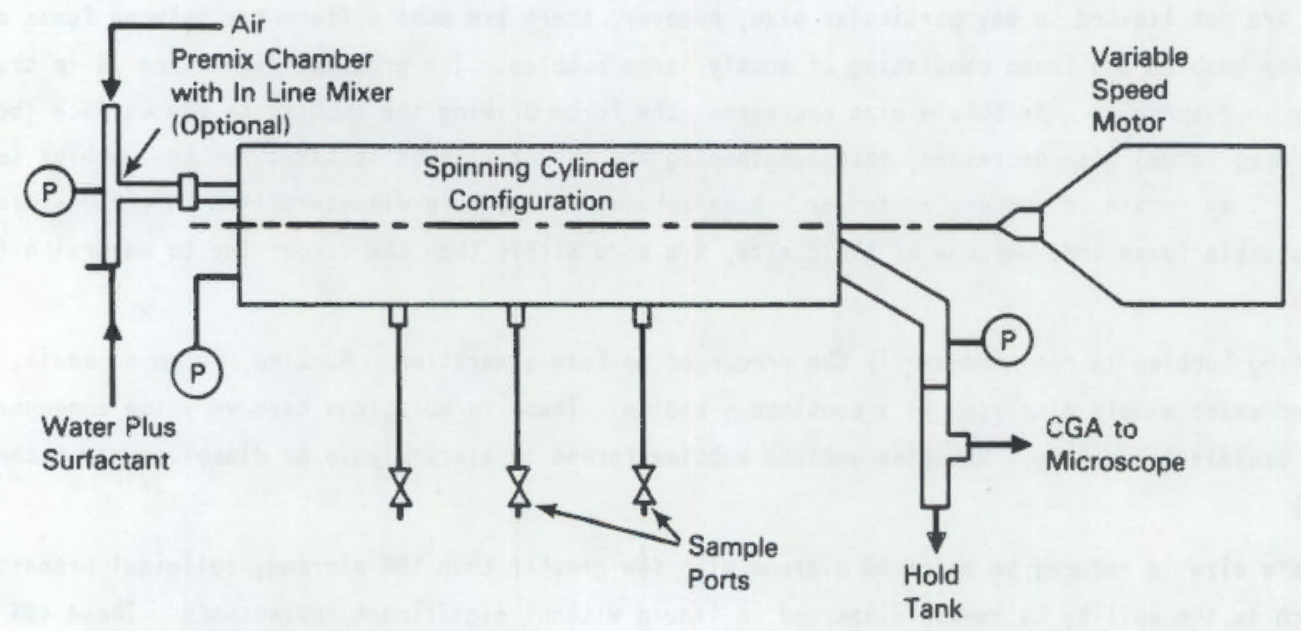

FICURE 9.1. Spinning Cylinder Ca Generator 
shear. The critical design and fabrication factors will be the weight balance of the spinning internal cylinder and the alteration of the internals to maximize production of an acceptable microbubble dispersion tailored to satisfy a particular application.

\subsubsection{Potential Energy Savings}

Using icrobubbles for flotation has potential because they are easy to generate and have high quality (bubble concentration), good stability (slow coalescence), and lisited void air. The first application of a nethod for producing commercial quantities of fine aicrobubbles could be for inproving flotation or separation of wastes containing natural surfactants. Foaning could be achieved using a low surfactant concentration of 100 to 300 parts per willion (ppa) with the packed bed generator, a device recently fabricated for generating microbubble foan (Suggs 1987) (see Section 9.2.5). Therefore, wastewater treatment (flotation) of food wastes, textile waste, perhaps paper wastes, and oily wastes from the metal cutting industry (aluminum, steel) are possible applications. In those treatments, little or no surfactant should have to be added.

Other flotations of phosphate slises, algae (harvesting), inorganic fine particulate, and coal benefaction flotation have also been addrossed successfully in the laboratory. In coemercializing those applications, a surfactant most likely would have to be added for processing.

An improved flotation technique ill be accepted if technical improvements can be made and its economics justified. In waste treatment, the amount and costs of subsequent biodegradation will be reduced if fine particles and dispersed oils can be removed and recoverad. Inproved pretreatment to renove particulate matter would also reduce the probability of hazardous refractory organics being carried through into secondary treatments and concentrating in the sludges. Therefore, both ease operation of secondary waste treatment and cleaner sludges for soil conditioning rather than landfilling could result.

Microbubble technology could have its greatest energy savings' inpact in biological systems. The primary application would be in improved, energy-efficient oxygen mass transfer for applications ranging fron biological reactors (ordinarily a naturally foaning broth) to activated sludge processing (using a foaming waste strean). A recently conpleted Y.S. thesis (writing stage) in our laboratory has clearly denonstrated considerable improvement in biological growth using CGA with much reduced agitation (energy savings). The dissolved oxygen in the reactor stayed much higher, and no surfactant had to be added. Any continuous con generator would have considerable application in this field and would have vide application in many biological systems where ans transfer of oxygen to a viscous broth is limiting.

The ajor cost in operating activated sludge processing plants that treat both sanitary and industrial waste is the enormous electrical cost for beating (sparging) air into the systen for biodegradation to occur. The larger 1000 to 3000 icron bubbles generated have a very high riaing velocity but a very lou utilization, about $8 x$ to 15\%. A pilot unit capable of generating large quantities of nicrobubbles ranging in size from 25 to 100 nicrons offers an option for those plants. Saller bubbles provide auch higher retention and result in utilization well above 5ex. The rising velocity is proportional to the bubble dianeter squared. However, the application would be restricted to systems having some foaning characteristics, such as certain foed streans and in-process streans.

An even larger market is the biodegradation (secondary treatment) of industrial and donestic sewage. Because CGhs have a strong tendency to be retained in saturated soil matrices, considerable testing has been under way to prove the feasibility of using CGAs to supply oxygen for biodegradation in the saturated zone (Micholsen, Wallis and Sebba 1984a, 1984b; Michelsen, Wallis and Lavinder 1985; Michelsen, Wallis and Sebba 1986). That application would coapete with sparged air and hydrogen peroxide addition processes and groundwater injection/recovery techniques. Currently, costs for providing oxygen using CGAs do not conpete with sparged and surface aeration techniques found in activated sludge treatment processing even assuning complete 100x oxygen use of all air formed into CGAs. However, where stripping of toxic volatiles from activated sludge processing is a 
concern and where activated carbon adsorption of vent fumes is contenplated, a closed systen using reinforced (high $\mathrm{O}_{2}$ ) air for generating CGAs and subsequent biodegradation could prove technically feasible and econonically acceptable.

In the new biotechnology areas, the use of small microbubbles for separation (flotation) of inpurities could offer long-ters opportunity for CGA utilization. Vith proper bubble formulation, selected adsorptions and separations aay be possible.

Using CGAs offers several other opportunities for saving energy. In aluninum slines' processing, CGAs have been demonstrated to enhance the recovery of an enriched aluminum cut for recycle. Landfilling costs and bauxite processing could be reduced if a greater percentage of aluminum could be recovered from ora. Sinilarly, using flotation to reduce sulfides and ash from finoly crushed coal has received considerable attention and looks proaising. The scaleup of CGA generation should provide bench-scale testing capability of the surface chenistry for separations and capacity for large-scale field testing. The change in U.S. energy needs to a natural resource such as a fine coal ground and floated to resove sulfur and ash represents an appealing answer to environmental and balance-of-trade problems.

\subsubsection{Technical Feasibility}

Thile the proposed generator is being fabricated, testing is continuing on several of the first-generation spinning eylinder adifications, shown in Figure 9.1. The test results with a uniqualy designed cylinder 'E' and internals are shown in Table 9.1. As the table shows, both rotameters were calibrated to indicate liquid and air rates. An inverted bucket was used to calibrate the air rotaneter. The total dispersion production was deternined by collecting the final dispersion at atmospheric pressure and measuring the volume collected during a 1-ninute interval. The rpa of the spinning systen was measured using a tachoneter. The stability, H', is deternined by taking a $250 \mathrm{al}$ sample of the product dispersion into a standard $250 \mathrm{al}$ graduate. Direct woighing provides the basis for deteraining the quality, and the volume of the clear liquid after one minute of bubble rise provides the basis for measuring stability.

Earlier studies by Suggs (1987) have shown that by correcting $H^{\prime}$ to a percentage of total rise (all bubbles cosleaced), this corrected $H^{\prime}$ or stability can be correlated as a function of quality. The higher the quality, the lower the $\mathrm{H}^{\prime}$ (better stability). The air utilization is an important deteraination because it provides a measure of the total air actually formed into microbubbles. The large void air, 6 , passing through the generator could interfere with the microbubble performance in most applications.

The power consunption was deterained by placing a known low resistor in series with the lead to the router used for testing and measuring voltage over both the resistor and the motor. With these measurenents, the wattage used by the router was deterained. The energy necessary to produce one liter per ainute of nicrobubbles (the product desired) was then calculated. Finally, the liquid in the dispersion was deternined by multiplying the total dispersion production by (one ninus the fraction product quality). Comparison of this calculated water rate to the calibrated rotaneter liquid rate provides a closure on the liquid aaterial balance.

Figures 9.2, 9.3,9.4, and 9.5 plot key information from testing conducted using cylinder 'B.' The sir rate was kept constant during all these tests. Figure 9.2 shows that increasing water rate results in lower stability (increased $H^{\prime}$ ). Also, the $H^{\prime}$ can be lowered by increasing the rpe, shown in Figure 9.3, but with a sacrifice in greater power input. To secure good air utilization, an increased water supply is needed, as shown on Figure 9.4. Also, as water rate is increased, the quality also increases, strongly indicating that turbulence and shearing have been enhanced to produce a higher air concentration but with little change in power per quantity of air formed as nicrobubbles. Figure 9.5 shows that utilization decreases vith rpm. At a high rpm, the centrifugal force most likely throws the liquid out toward the wall and nixing is inpaired. High rpa produces good nicrobubbles but has poor utilization and high energy denand. A higher foan quality (air to liquid mixture) can be produced but results in larger bubbles ( $H^{\prime}$ greater) as water flow rate increases with constant air supply. 
TABLE 9.1. Hicrobubble Generation Using Spinning Cylinder 'E'

\begin{tabular}{|c|c|c|c|c|c|c|c|c|c|c|}
\hline $\begin{array}{l}\text { Run } \\
\text { No. }\end{array}$ & $\begin{array}{l}\text { Rotaneter } \\
\text { Air Rate } \\
\text { L/ain. }\end{array}$ & $\begin{array}{c}\text { Rotaneter (a) } \\
\text { Liquid } \\
\text { Rate } \\
\text { L/min. } \\
\end{array}$ & $\begin{array}{l}\text { Total } \\
\text { Dispersion } \\
\text { Production } \\
\text { L/ain. } \\
\end{array}$ & RPH & $\begin{array}{c}\text { Stability }{ }^{(b)} \\
\mathrm{H}^{1}, \mathrm{~L} \text { in. } \\
\text { One ain. }\end{array}$ & $\begin{array}{l}\text { Quality } \\
\text { Percent } \\
\text { Air in } \\
\text { Total } \\
\text { Dispersion }\end{array}$ & $\begin{array}{c}\text { Utilization (c) } \\
\text { Percent } \\
\text { Air in } \\
\text { Forming } \\
\text { Dispersion } \\
\end{array}$ & $\begin{array}{l}\text { Power } \\
\text { Consumer } \\
\text { Watts } \\
\end{array}$ & $\begin{array}{l}\text { Power per }(\mathrm{d}) \\
\text { Microbubbles } \\
\text { Generated } \\
\text { Watts/(L/min.) }\end{array}$ & $\begin{array}{l}\text { Liquid in } \\
\text { Dispersion } \\
\text { Production, } \\
\text { L/min. } \\
\end{array}$ \\
\hline E1 & 13.8 & 4.1 & 16.4 & 5000 & 7.6 & 71.0 & 85.6 & 149.6 & 12.85 & 4.7 \\
\hline E2 & 13.6 & 6.3 & 18.8 & 5460 & 7.5 & 88.5 & 94.7 & 183.7 & 14.26 & 5.9 \\
\hline E4 & 13.6 & 6.8 & 26.6 & 5000 & 12.5 & 64.5 & 95.6 & 147.7 & 11.45 & 7.1 \\
\hline E6 & 13.6 & 8.1 & 20.6 & 5080 & 14.5 & 62.0 & 91.2 & 168.5 & 13.59 & 7.6 \\
\hline E7 & 13.6 & 10.2 & 23.2 & 5860 & 25.5 & 56.5 & 96.4 & 168.0 & 12.82 & 16.1 \\
\hline E3 & 13.6 & 6.8 & 19.8 & 3460 & 18.5 & 66.0 & 95.1 & 91.2 & 7.65 & 6.64 \\
\hline E5 & 13.6 & 6.8 & 19.9 & 7960 & 7.6 & 65.5 & 95.8 & 318.7 & 32.65 & 6.87 \\
\hline EB & 13.8 & 10.2 & 24.8 & 3000 & 47.0 & 57.6 & 103.6 & 87.8 & 6. 23 & 10.7 \\
\hline E9 & 13.6 & 10.2 & 24.8 & 7060 & 10.5 & 55.5 & 101.0 & 332.1 & 24.14 & 10.8 \\
\hline
\end{tabular}

(a) Tap water coptains 460 ppn sodiun dodecyl benzene sulfonate.

(b) Stability, $\mathrm{H}^{\mathrm{L}}$, is $\mathrm{mL}$ of liquid phase separation one minute after filling standard $250 \mathrm{~mL}$ graduate.

(c) Utilization is dispersion production $x$ quality/rota air, eq (E1) $16.4 \times .71 / 13.6=85.8 x$.

(d) Power per production of nicrobubbles eq (E1) $149.6 /(16.4 \times .71)=12.85$. 


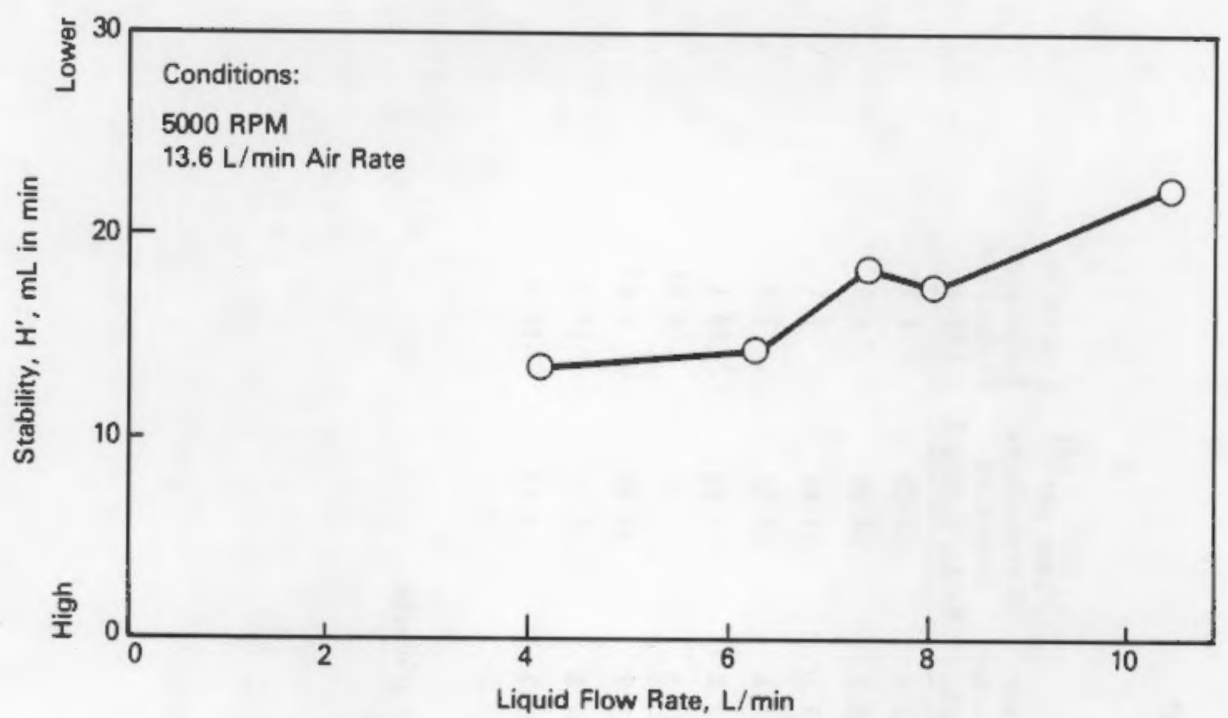

FICURE 9.2. Stability as a Function of Liquid Flow Rate ("B' conf iguration)

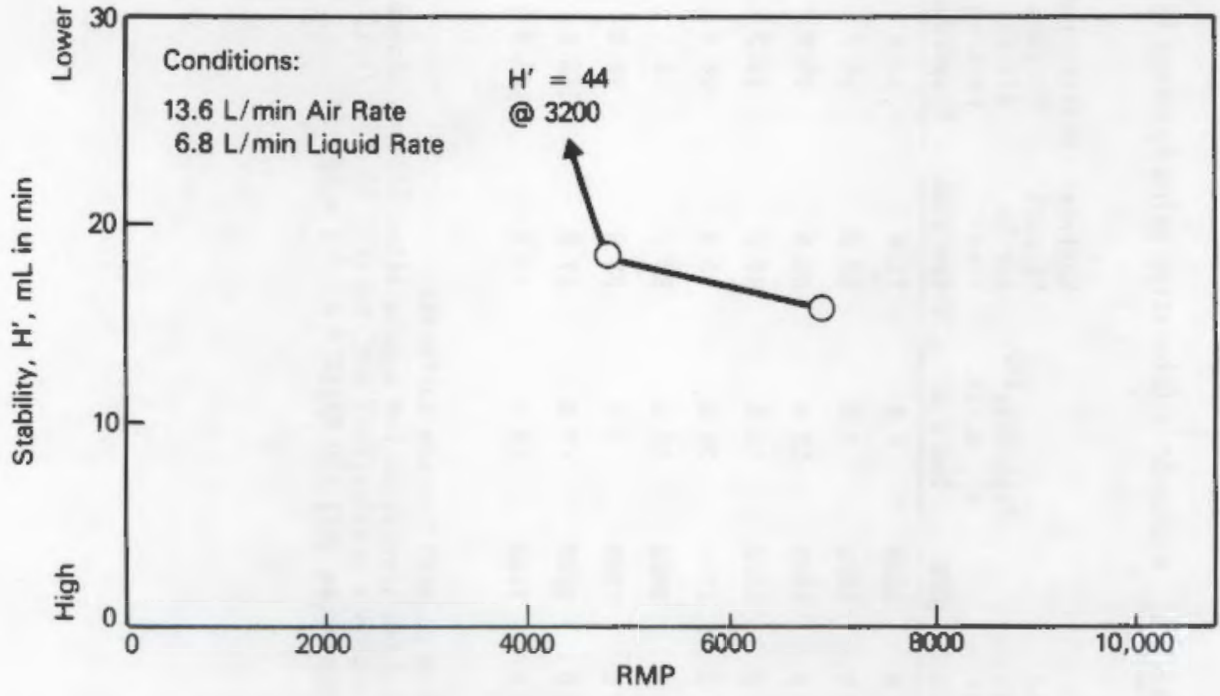

FIGURE 9.3. Stability as a Function of RPU or Spinning Device ("B" configuration)

Figures $9.6,9.7,9.8$, and 9.9 show the results of testing with the spinning cylinder 'E' configuration; see Table 9.1 for details. Again, increasing flow results in decreased $H^{\prime}$, meaning that bubble size is diainished. However, air utilization remains flat across the entire range; and quality, while dropping as flow rate increases (see Table 9.1), was significantly higher than testing with the B configuration. Aiso, rpa had little influence in utilization although stability was poorer, using only $3000 \mathrm{rpm}$.

In summary, the 'E' configuration significantly improves the generation of a aicrobubble dispersion with lower energy inputs. Of particular importance is the relatively constant air utilization over a range of operating conditions. The energy inputs, while believed to be comparable (precise) between runs within the $B$ and E sets, ay not be accurate. The standard low OHM resistors that were used drifted from set to set. 


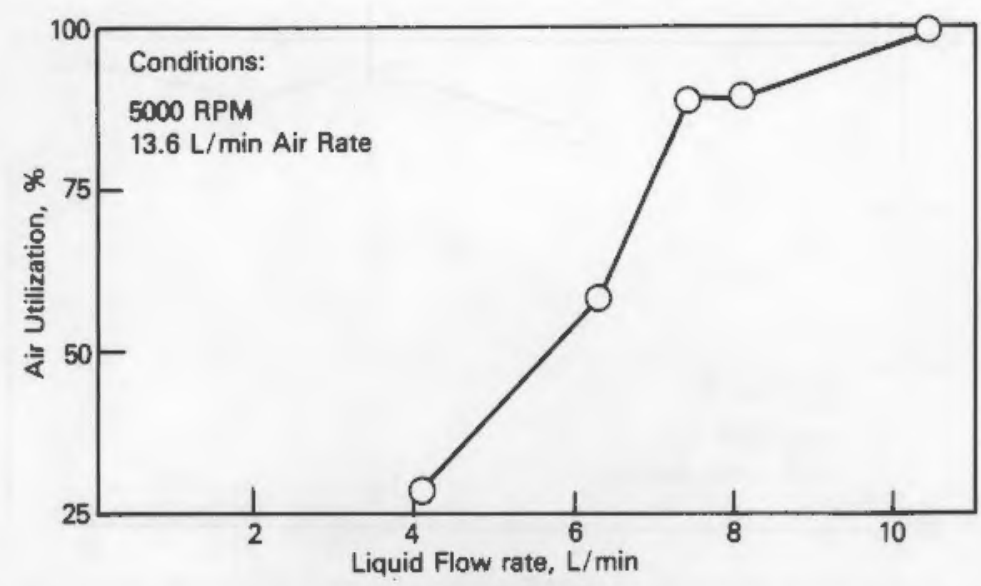

FICURE 9.4. Air Utilization (nicrobubbles formed) as a Function of Liquid Flow Rate ("B'configuration)

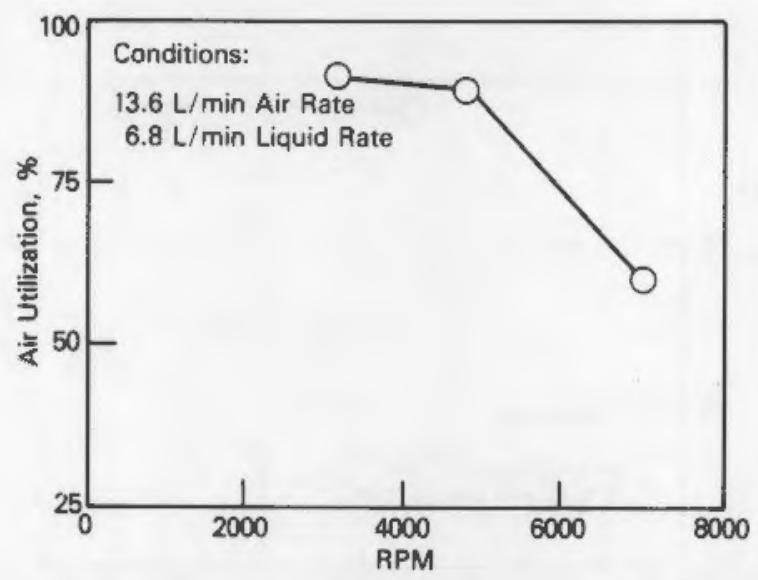

FIGURE 9.5. Air Utilization (nicrobubbles formed) as a Function of Spinning Device ("B' configuration)

\subsubsection{Impedinents to Widespread Use}

Conerating a large quantity of a microbubble dispersion containing 25 to 110 aicron bubbles appears to be technically feasible. However, to produce these nicrobubbles, some source of natural and/or additional surfactant (100 to $500 \mathrm{ppm}$ ) aust be present to lower the surface tension in order to form and stabilize the aicrobubbles. Also, a greater energy input is required to generate the expected dispersion, partly because of the viscosity of the dispersion generated. Using a spinning cylinder viscosimeter, the observed viscosity of the 49x, 50x, and 60\% dispersion (percentage of nicrobubbles dispersion) was $10 \mathrm{cp}$ but increased to $30 \mathrm{cp}$ at a $70 x$ nicrobubble dispersion. Therefore, efforts must be directed at optinizing nicrobubble production and minimizing energy input and raw material (surfactant) cost.

\subsubsection{Prior Work and State of the Art}

Gas aphrons were first produced in the laboratory by Sebba (1971) using the venturi method. This method essentially depends upon the fast flow of a dilute surfactant solution past a venturi throat, at which point there is a provision for entry of the gas, under about one atmosphere excess pressure, through a very narrow channel.

Several years later, Sebba (1985a) developed an improved technique for producing Cas: the spinning disk. That method uses a small disk rotating in excess of 4000 rpm between two carefully positioned baffles in a 


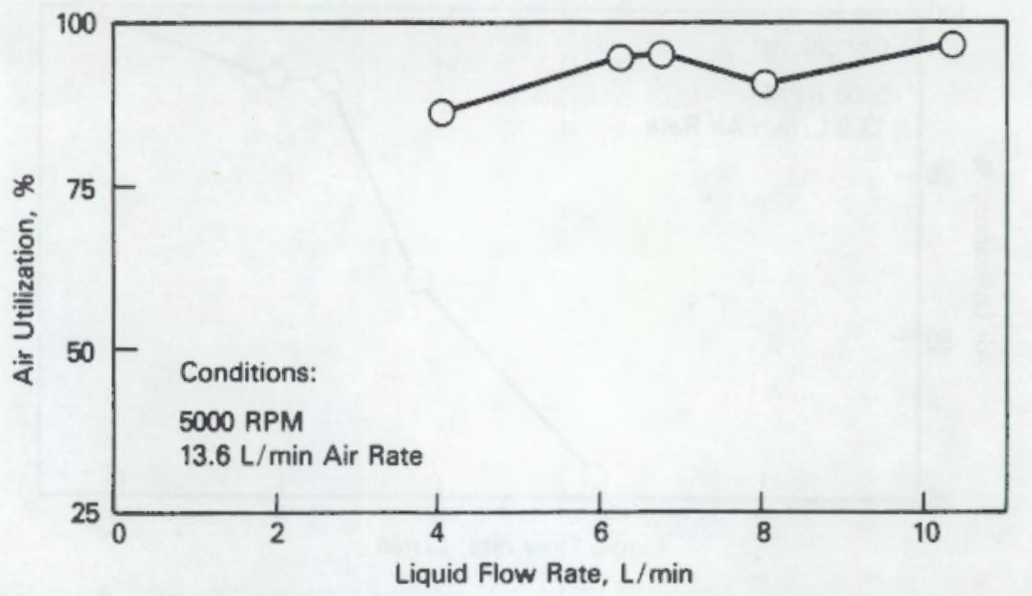

FIQURE 9.6. Air Utilization (nicrobubbles formed) as a Funetion of Liquid Flaw Rate ('E' configuration)

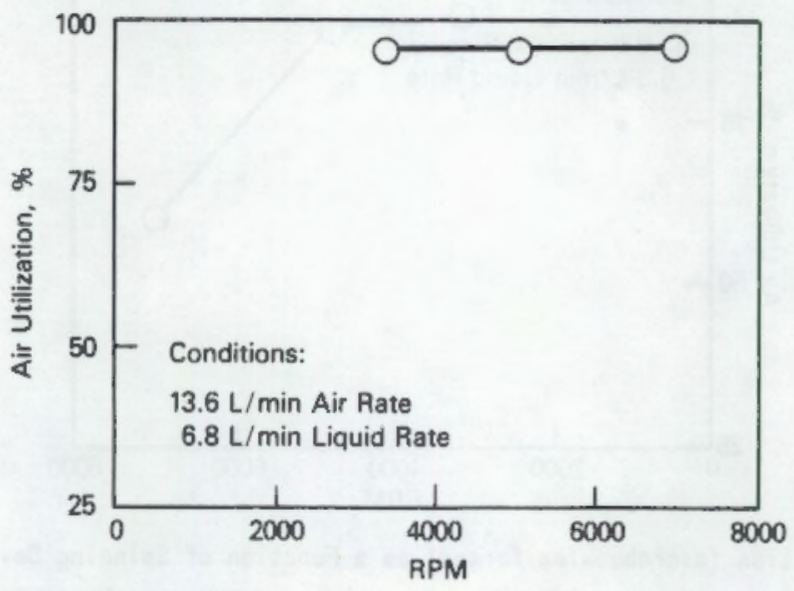

FIGURE 9.7. Air Utilization (nicrobubbles formed) as a Function of RPM of Spinning Device ("E' configuration)

container filled with dilute surfactant solution. Since the introduction of the spinning disk technique and its ability to generate CGAs at $4 \mathrm{~L} / \mathrm{min}$, no other generating techniques have been tested. The advent of this colloidal systen and the ways of generating it opened up new avenues for separation techniques and provided new solutions to old problens. Sebba $(1985 b)$ has identified the following applications:

- stripping of dissolved gases from water

- renoval of finely dispersed oils fron water

- ion and precipitate flotation

- removal of ash forming materials fron coal

- renoval of oil from sands

- flotation of microorganisns such as algae and bacteria

- oxygen transport to subsurface matrices.

Unfortunately, generation techniques have been liaited to producing only small anounts of CGks. However, all of these applications, if coanercialized, would require much greater quantities of a microdispersion of air bubbles in water. Because of this denand, a technique for generating "connercial" anounts of CGAs is needed. Scaled-up versions of the venturi and batch spinning disk aethods should meet the requirenents, but have not been successful. Sebba (1985a, 1985b) ruled out the possibility of scaling-up the venturi technique. 


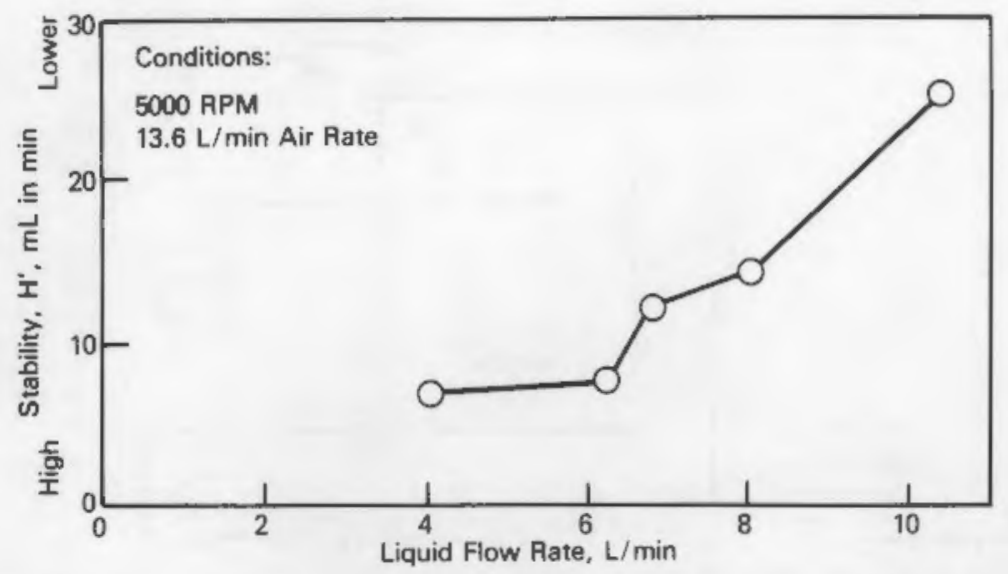

FICURE 9.8. Stability as a Function of Liquid Flon Rate ('E' configuration)

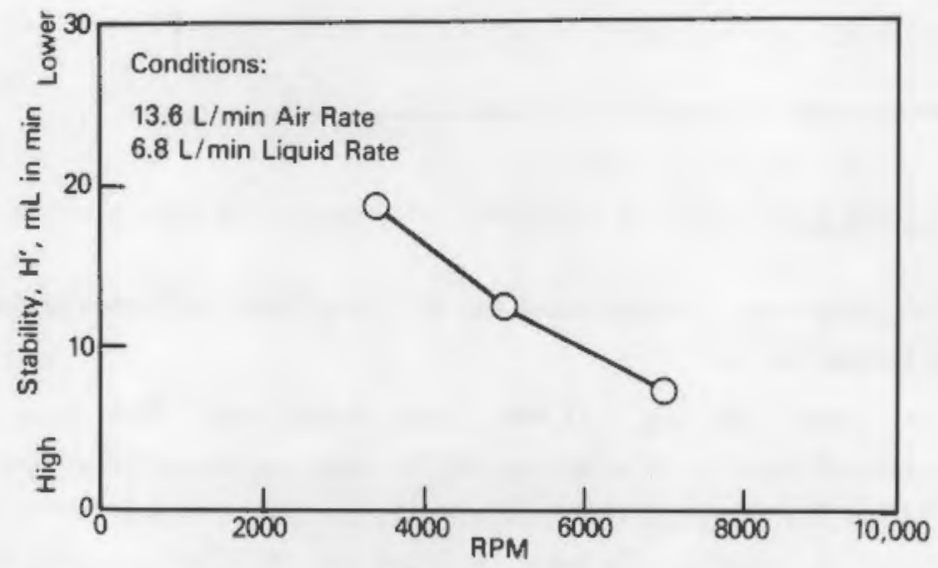

FICURE 9.9. Stability as a Function of RPU of Spinning Device ('E' conf iguration)

Recently, Suggs (1987) designed and fabricated a portable pilot unit for generating microbubble foan and tested a packed bed generater device using glass spheres. This technique has produced large quantities af good CGAs with bubble size distribution apprasching those produced with a spinning disk. Figure 9.10 shows a schematic of the pilot plant unit that will be sodified to replace the packed bed with a spinning eylinder device.

Suggs' studies also have led to standardization of several methods for rapidly deternining cGA characteristics. The stability of the CCAs is deterwined by following the rise velocity of the liquid phase as the bubbles are placed in a standard 250 al graduate cylinder. Also, by placing a small cell on a aicroscope, Suggs has quantified bubble size distribution from photographs of the video display. The sample Iine shown on Figure 9.1 was the continuous source of nicrobubbles flowing through the cell. The flow was turned off during photographing. The research continues on using CGAs for in situ treatwent of hazardous waste, and fundanental or cGA transport through soils.

A recent laboratory study has been completed using CGA for flotation of fine particulates. One unpublished study on suspended fine particulates ( $\mathrm{Clay}$ ) at the $30 \mathrm{ppm}$ level showed that CGA flotation could reaove $95 \%$ of the suspended matter while dissolved air flotation removed only 50x using the same air voluae for flotation. A 


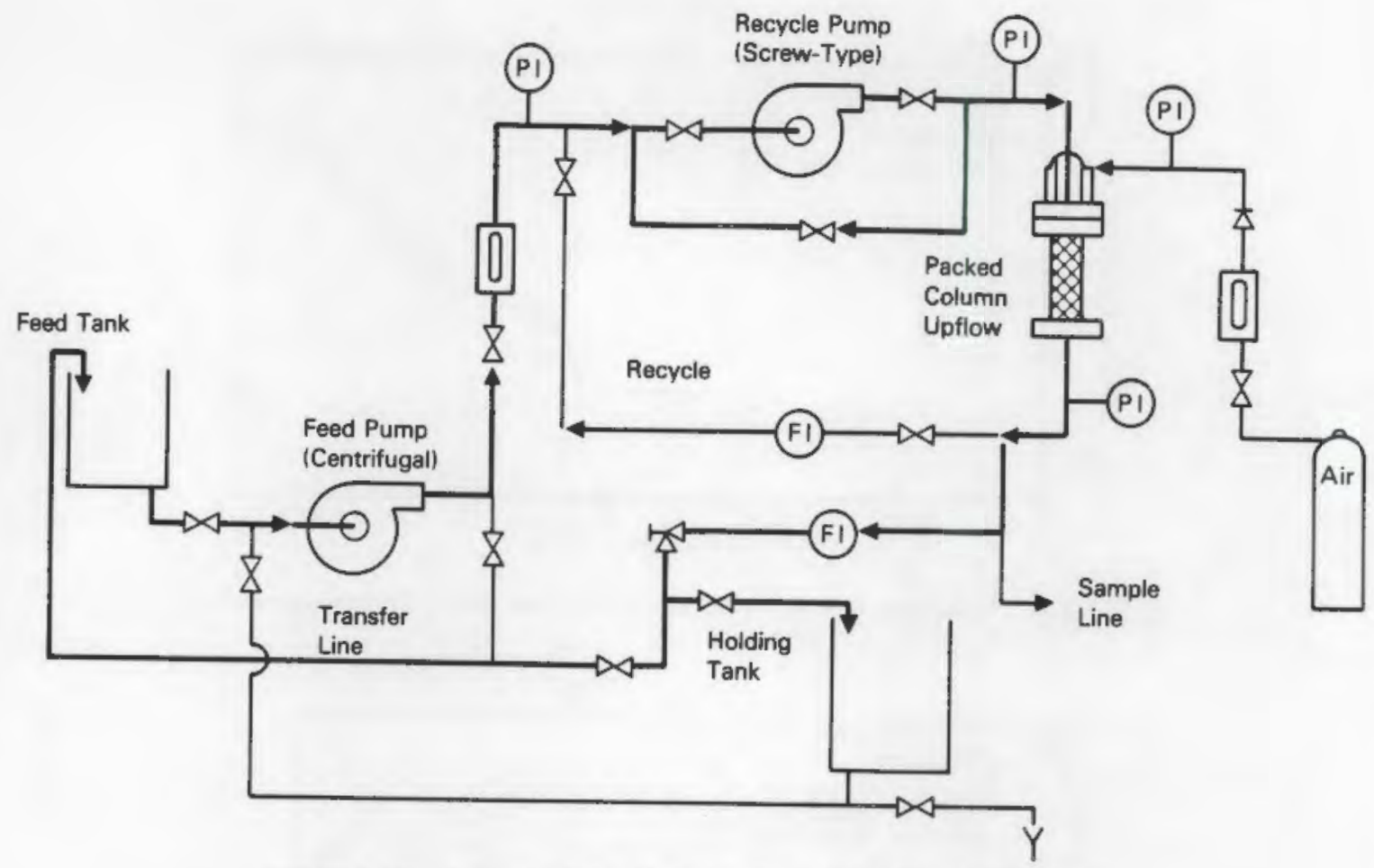

FIGURE 9.10. Portable Pilot Unit for Generating Nicrobubble Foan

second study by Lohse (1986) has clearly demonstrated the ability of CGAs to float algae effectively in a countercurrent flotation chamber design.

A pilot flotation cell (tank) $6 \mathrm{ft}$ long, $1 \mathrm{ft}$ deep (front to back) and $4 \mathrm{ft}$ high has been designed and constructed to test the scale-up feasibility of using CGs for removing contaninants from water. Several test runs were made in the Chemical Engineering Unit Operations laboratory determine if the flotation tank and CGA generation system would function properly. The tests indicated that the flotation tank performed well and that CGAs could remove suspended particles fro contaninated water in larger-scalo testing.

Figure 9.11 shows the proposed CGA generation configuration for field testing. This system can easily be changed for dissolved air flotation performance operation. Any field teating to be conducted will most likely include particulate or oil flotation using a portable flotation tank having the same dimension as the pilot cell.

\subsection{FUTURE DEVELPMENT OF THE CONCEPT}

Comercial testing at the following facilities is being negotiated. One of the two following tests vill be conducted:

1. In situ testing using pilot quantities of CGAs as a direct replacement may be conducted at a turkey processing facility near Harrisonburg, Virginia. The other option is to take a side strean and test flotation in the pilot flotation cell described earlier and compare performance with the existing flotation systen. CGAs would be supplied by the pilat CGA generator.

2. Testing may be conducted at a Reynolds motal aluminum fabrication facility in Charlotte, North Carolina. The possible arrangenents are similar to those described above except that CGA generation would probably require the addition of some sodiun dodecyclbenzene sulfonate to assure that stable nicrobubbles are generated. 


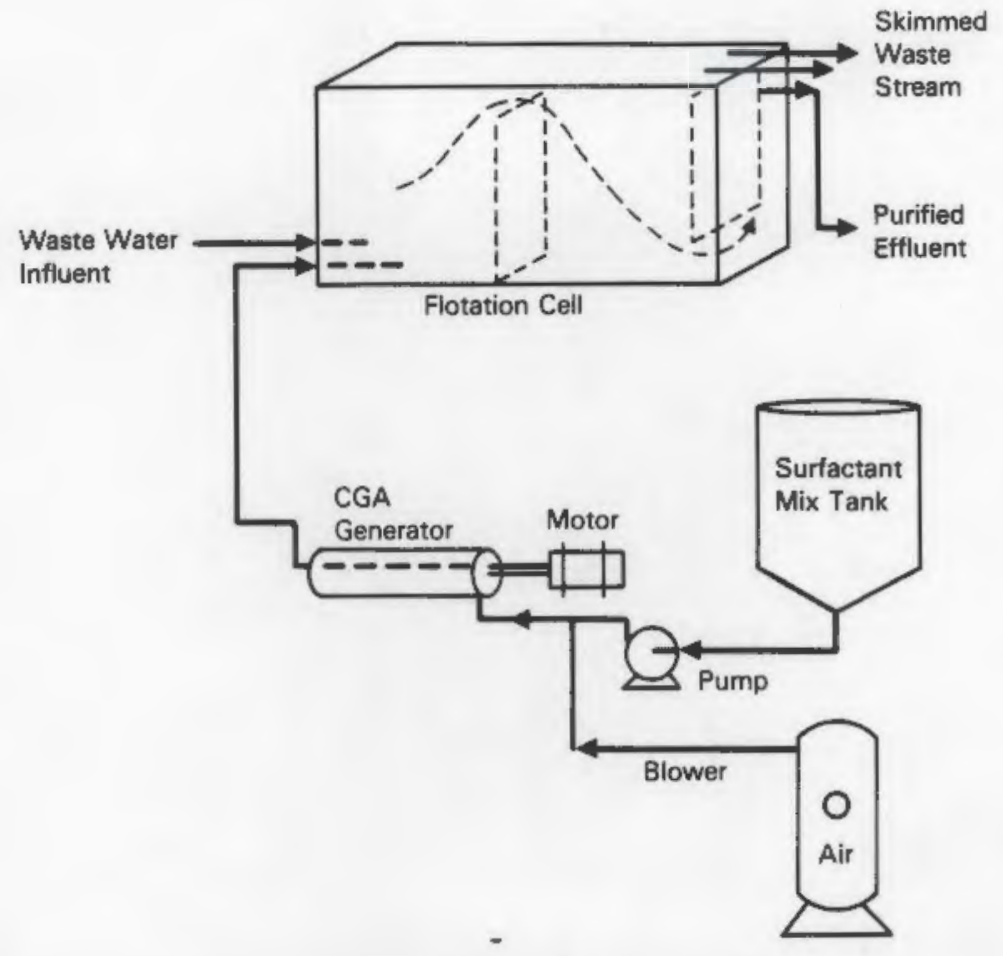

FICURE 9.11. Flotation Cell and CQA Ceneration Systen

\subsection{REEERENCES}

Lohse, 1. H. 1986. 'Separation of Algae fron Gross Wedia by COA Flotation." Master Thesis, Virginia Tech, Blacksburg, Virginia.

Michelsen, D. L., D. A. Mallis and S. R. Lavinder. 1985. 'In-Situ Biodegradation of Dispersed Organisas Using a Microdispersion of Air in Water," pp. 291-298 in Proceedings of Bth National Conference on Management of Uncontroll ed Hazardous Waste Sites, Washington, D.C. Presented and published by Hazardous Waterials Control Research Institute.

Michelsen, D. L., D. A. Wallis and F. Sobba. 1984a. 'In-Situ Biological Oxidation of Hazardous Organics Using Colloidal Gas Aphron Systens." Env. Prog. 3(2):103-107.

Michelsen, O. L., D. A. Tall is and F. Sebba. 1984b. The Use of a Mierodispersion of Air in Vater for In Situ Treatment of Hazardous Drganics, " pp. 398-403 in Proceedings of Fifth National Conference on Management of Uncontrolled Hazardous Waste Sites. Presented and published by Hazardous Waterials Control Research Institute.

Michelsen, D. L., D. A. Wallis and F. Sebba. 1986. 'The Use of 'Aphron' Techniques for Treating Hazardous Vastes. Torld Congress III of Chenical Engineering, Vol. 3, pp. 592-595, Tokyo, Japan, Septenber 22.

Sebba, F. 1971. "Microfoans--An Unexploited Coiloid Systen." J. Coll. Interface Sci. 35(4):643-646.

Sebba, F. 1981. "Investigation of the Hodes of Contaninant Capture in CGA (MCD) Foans." OWRT/RU-82/16, U.S. Departant of the Interior, Office of Water Research and Technology, Washington, D.C.

Sebba, F. 1985a. 'An Inproved Generator for Mieron-sized Bubbles.' Chen. Ind. pp. 91-92.

Sebba, F. 1985b. 'Separations Using Aphrons.' Sep. Purif. Mothods. 14(1):127-148.

Sebba, F. 1987. Foans and Biliquid Foans - Aphrons. John Viloy S Sons, Chichester, Great Britain.

Sebba, F., and S. M. Barnett. 1981. 'Separations Using Colloidal Gas Aphrons." In Proceedings of the Second International Congress of Chenical Engineering. Vol. IV, p. 27.

Suggs, J. A. 1987. Generation of Uicrobubble Foan Using a Packed Coluan. M.S. Thesis, Virginia Tech, Blacksburg, Virginis. 



\title{
10.6 APPLICATIONS OF A MAGNETIC CYCLONE
}

\author{
Dr. John L. Watson \\ Department of Metallurgical Engineering \\ University of Missouri-Rolla
}

ABSTRACT

This concept addresses two potential applications of a magnetic cyclone. The first application exanines and denonstrates improved recovery of fine magnetite. The fine magnetite used in conventional dense aedia plants for coal cleaning is not fully recovered and recycled. The project results show that the nagnetic cyclone can recover dense media magnetite (as purchased by operators of dense media coal cleaning plants) effectively without excessive magnetic fields or feed pressures. However, when sanples from process streans of coal cleaning plants were used, the recoveries were lower than with pure magnetite, largely because of the very $f$ ine size of the magnetic particles in the process streans. Additional tests will exanine cyclone geonetry and magnetic field variations to further improve the aagnetic cyclone recovery of these fine particles.

The second application concerns dewatering of steel plant sludges to allow these iron-bearing naterials to be disposed of or reused. To date a literature search has been undertaken to determine the characteristics and potential of this application. Unfortunately, appropriate plant samples were not available in time to conplete the research, but tests should be finished by the end of April 1988, when a final report will be wade available.

\subsection{INTRODUCTION}

The scientific concept of combining aagnetic forces with classification forces within a hydrocyclone was investigated in New Zealand about ten years ago by Or. J. L. Watson for possible use in beneficiation processes. This work is reported in a master's thesis (Hiew 1980). The intended used of the device was the separation of titanonagnetite fron gangue ainerals in an ironsands wining operation.

Traditionally, such beneficiation has been conducted using separate magnetic and gravity processes in series (Watson 1978; Watson and Low 1982). Using the magnetic cyclone in that application was found to be very limited because of the relatively coarse size of the sands, ranging between 100 and 600 aicrons. The difficulties encountered included the generation of a magnetic field gradient, across a cyclone, of a sufficient size to permit separation of the sands. Probless also were encountered in the laboratory with handling the large flow rates needed to operate a cyclone of this aize.

Comnercialization of the nagnetic cyclone appears to depend on successful denonstration of process applications for the concept. This project targeted two opecific applications for research and investigation:

- recovery of magnetite dense nedia in dense nedia coal cleaning plants

- recovery of solids from waste sludges in the steeleaking industry

Both applications involve materials that have particlo sizes generally less than 50 microns in diameter and that exhibit a strongly magnetic character. The proposed processes are essentially solid recovery techniques.

\subsection{DESCRIPTION OF THE CONCEPT}

The scientific principle of the concept of the magnetic cyclone is well established (Watson and Amoko-Gyampah 1983; Fricker 1985). It involves the use of magnetic force in a radial direction across a cyclone, 
where existing centrifugal, viscous, and gravitational forces act on particles in a fluid. The fluid used to transport the particles into the cyclone way be air or water, with water boing the prime aediun in wineral processing operations.

A hydrocyclone is a device that peraits particles in water (pulp), fed tangentially, to be separated according to size and density. Figure 10.1 illustrates the essential forces involved in the separation.

Centrifugal forces compote with viscous drag forces to deteraine whether a particle will exit the cyclone through the spigot (underflow) or vortex finder (overflow). If a particle reaches the cyclone's outer wall, it will discharge through the spigot as underflow, which contains the coarser aterial. On the other hand, if the water drag forces pull the particle towards the center of the cyclone, it will be discharged through the vortex finder as overflow, which contains finer material.

The separation size, or $d_{50}$, of a cyclone is doninated by the cyclone radius because of its importance in calculating centrifugal force. To achieve a separation size of greater than 75 icrons, a cyclone of at least $56 \mathrm{cn}$ diameter typically is required. To achieve a separation size of less than 46 microns, the cyclone diameter must be reduced to $10 \mathrm{ca}$ or smaller. Although the cyclone's cylindrical dianeter has the major influence over the separation size, both increasing flow rate and particle density vill decrease the separation size, while an increasing pulp viscosity will increase it.

Recovering particles finer than 25 aicrons to the spigot is very difficult, as shown in Figure 10.2, where a classification curve plots the fraction of each size range reporting to the spigot product. This curve represents data for recovering agnetite $\left(\mathrm{Fe}_{3} \mathrm{O}_{4}\right)$ in a $7.5 \mathrm{~cm}$ aluminum cyclone (Watson and Amoko-Gyampah 1983). As the figure shows, the separation size is 35 sicrons, and below 10 mierons as little as $16 x$ nay be recovered to the spigot. The renainder flows to the vortex finder product, along with nost of the water.

In many applications the recovery of particles finer than 10 microns is important and is achieved, at the expense of throughput, by using very small-dianeter cyclones. One such cyclone is a multicyelone (2.5 ea dia.), which is used in gas cleaning or dedusting. If the particles are angnetic, a magnetic force can be used, in addition to existing forces, to attract the particles to the outer wall of the cyclone and hence to spigot

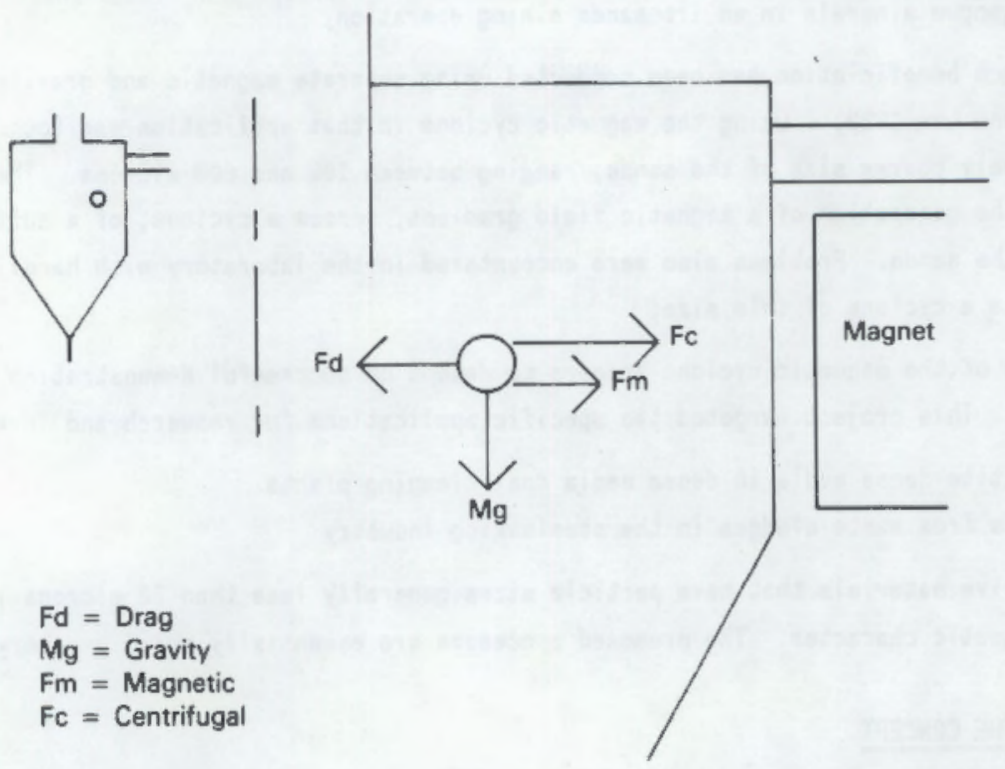

FICURE 10.1. Force Illustration for Conventional and Magnetic Cyclones 


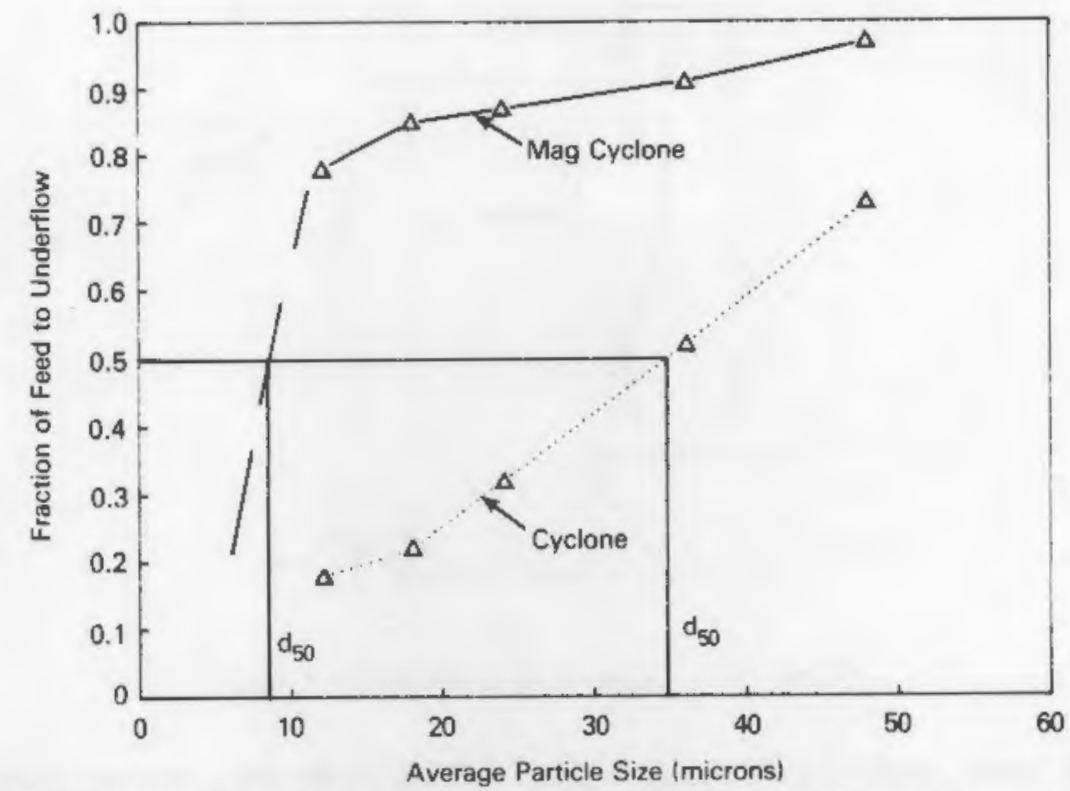

FICURE 10.2. Classification Curves for Conventional and Magnetic Cyclones

recovery. Figure 10.1 shows, in addition to the classification forces, these magnetic forces superiaposed on a particle in a hydrocyclone. Reinforcing outward radial forces decreases the separation size and therefore recovers finer material to the spigot.

The classification curve of $7.5 \mathrm{~cm}$ dianeter magnetic cycione is also shown in Figure 10.2. The effect of adding a magnetic force to this cyclone for treating magnetito is draatically ovident (Watson and Amoko-Gyanpah 1983). The separation size decreased fron 35 aicrons to less than 10 aicrons when the magnetic field was applied, indicating that the magnetic cyclone has considerable potential in treating fine magnetic materials.

In both of the proposed applications, it is important to recover as auch of the magnetic material as possible in the apigot product. To do this, the magnetic field must be of sufficient strength and field gradient to nove $f$ ine partieles to the cyclone wall. Previous work has suggested that for ferromagnetic materials, such as magnetite, the field strength need not exceed 560 gauss, but the field gradient should be in excess of 50 gauss/cm (Watson and Amoko-Gyampah 1983). Using these conditions as a starting point, the two proposed applications of a magnetic eyclone were investigated.

\subsection{TECHNICAL FEASIBILITY}

In this section, the concept's technical feasibility and experiantal results are discussed. The setup and procedure for the test cireuits are discussed first, followed by the results of experinents conducted to date on both applications of the concept.

\subsubsection{Test Cireuit Setup and Procedure}

A $5 \mathrm{~cm}$ (2') polypropylene cyelone was purchased and mounted in a test circuit, as shown in Figure 10.3. The eyclone was fitted with $0.4 \mathrm{~cm}\left(0.125^{\prime}\right)$ spigot, but also had an adjustable rubber spigot, which al lowed an outlet of $0.8 \mathrm{~cm}$ or less to be used. The magnetic field was provided by two permanent horseshoe magnets with gaps of $8 \mathrm{~cm}\left(3.2^{\circ}\right)$ and pole face areas of $18 \mathrm{~cm} \times 11 \mathrm{~cm}\left(7^{\circ} \times 4.2^{\prime}\right)$. The field strength in the gap of each magnet varied between 2 kilogauss, at $1 \mathrm{em}$ from the pole face, to $1.6 \mathrm{ki}$ logauss in the center of the air gap. Typical field gradients within the air gap were 75 gauss/en in the center and 200 gauss/en at the top and botton of the pole faces. Therefore, the cyelone was placed adjacent to the air gap to ensure a maximun field gradient. The circuit was operated at various pressure drops, but most tests used 6 psi. The sunp was filled with water to 


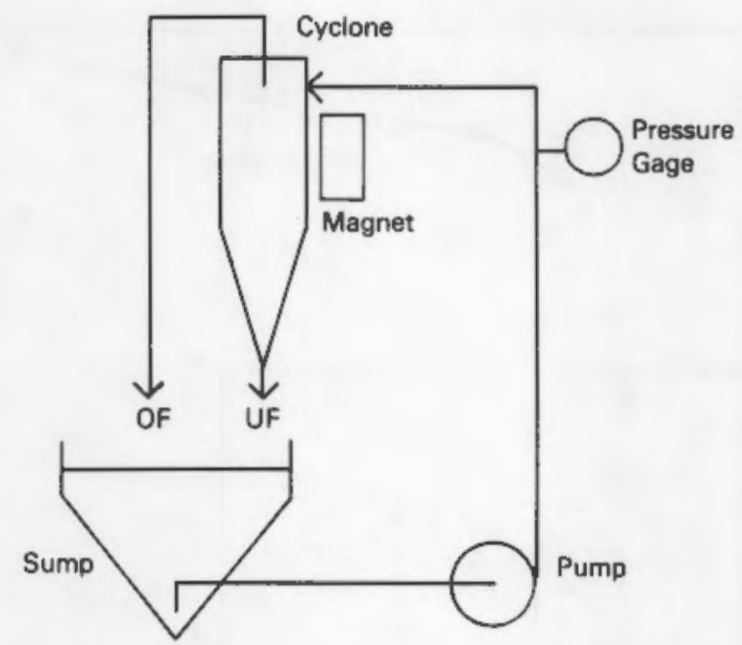

FIGURE 16.3. Laboratory Experimental Circuit

give a volume of 66 liters, with a typical solids loading of $500 \mathrm{~g}$ ( $1 \times$ solids). However, some tests used $5506 \mathrm{~g}$ of solid, giving a puip density of almost $10 x$ solids. The flow rate through the cyclone averaged approximately 30 liters/vin at $6 \mathrm{psi}$, with a solids rate of $240 \mathrm{~g} / \mathrm{min}$ at the lower pulp densities.

Three circuit configurations were used: 1) no magnet, 2) one agnet, and 3) two magnets. Figure 16.4 shows a plan view of the magnet/cyclone configuration; in the single-nagnet mode the field gradient across the cyclone exceeds 360 gauss/cm.

\subsubsection{Application 1 - Dense Media Magnetite Recovery}

Unwanted minerals can be removed from ained coal by various techniques (Leonard and Mitchell 1968), but one very important mothod is dense media separation. In that process, shown in Figure 10.5, the coal is fed to a bath filled with a suspension of fine magnetite in water. The density of the suspension usually ranges from 1.25 to $1.59 \mathrm{~g} / \mathrm{ec}$. Because the cosl is lighter than the suspension, the cosl will float and the heavier gangue or waste ninerals vill sink.
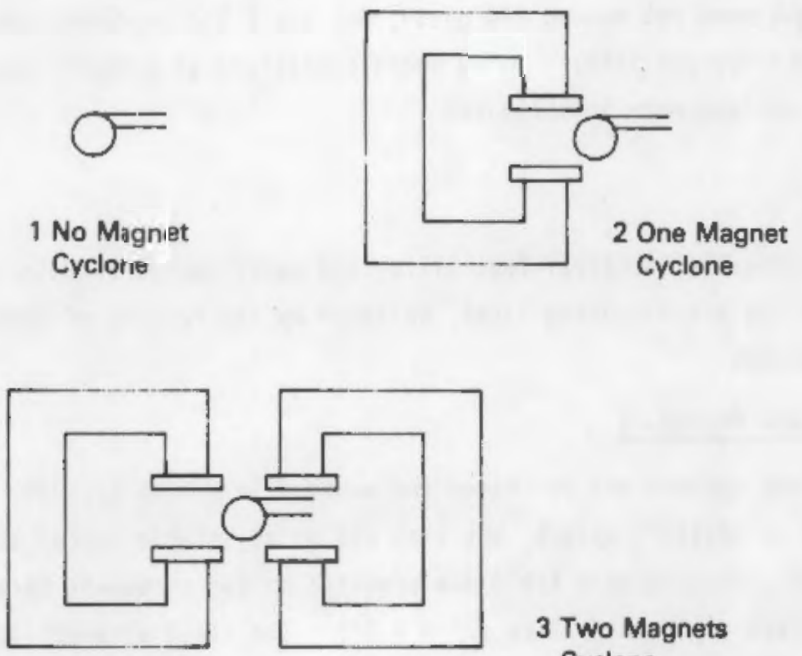

3 Two Magnets Cyclone

FICURE 10.4. Laboratory Magnet/Cyclone Conf iguration - Plan View 


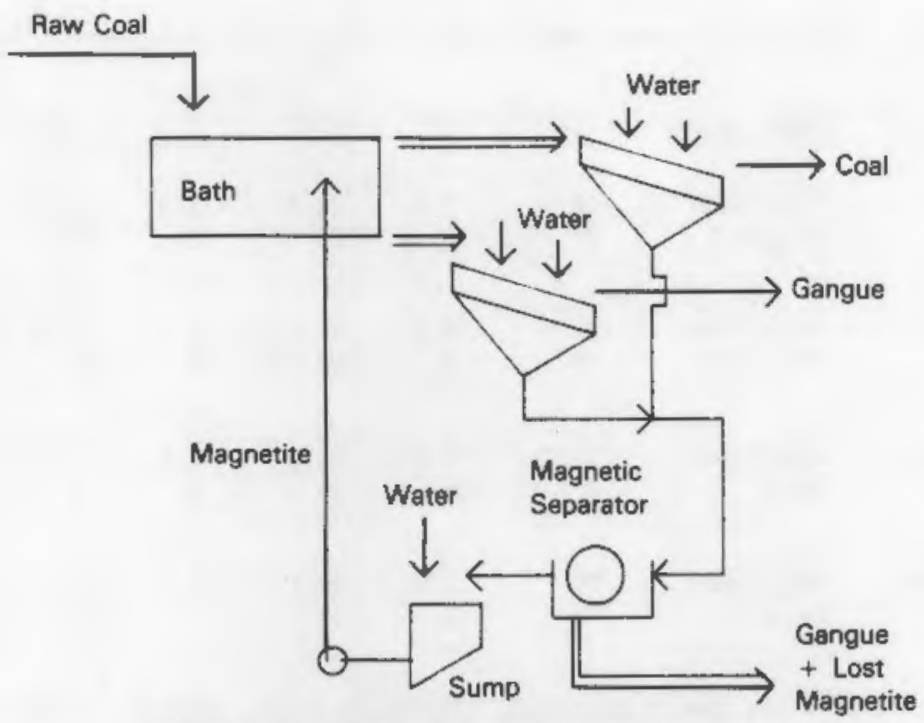

FICURE 10.5. Typical Coal Preparation Circuit

It is vital to the operation of this process that the manetite is recovered from the coal and the gangue mineral products for reuse in the bath. This is normally achieved by washing the angnetite off the products on screens, and then recovering the magnetite fron the dilute pulp using drun magnetic separators. These separators use low-strength magnetic fields (less than 1060 gauss) resulting from permanent magnets placed within the drua shell. Obviously the magnetite is very fine to ensure a stable suspension. Table 16.1 gives a typical size distribution of magnetite purchased by operators of heavy media coal cleaning plants.

By using drum magnetic separators, nost of the magnetite can be recovered, although some plants report aagnetite losses as high as two to three kilograns per tonne of coal treated. A recent study by the Electric Power Research Institute (1987) estimated that 50 aillion tonnes of coal were cleaned by magnetite-based processes in 1985. This number is projected to rise to 285 million tonnes by 1990 . Therefore, the loss of only few kilograns per tonne of coal treated can amount to many hundreds of thousands of dollars for a plant treating 1 aillion tonnes of coal annually.

Currently, U.S. supplies of magnetite are linited, and because it is not a high-priced product, transport represents a significant cost. The use of foreign supplies could result in higher magnetite prices, and therefore agnetite recovery processes represent an inportant area for dense media plants and aerit further investigation.

\section{Reference Tests with Pure Magnetite}

To study the performance of the circuit, tests were initially conducted with pure magnetite, as purchased by heavy media coal cleaning plant operators. Three-cireuit configurations were used at pressure drops of 8 , 15 , and $26 \mathrm{psi}$. The spigot dianeter for these tests was $9.8 \mathrm{~cm}$.

The test results are suanarized in Table 16.2 for pulps of $1 \times$ solids and show that pressure only has a significant effect on agnetite recovery to underflow (U/F), when there is no magnetic field. As would be

TAQLE 10.1. Magnetite Size Distribution

$\begin{array}{lccccc}\text { Size (microns) } & 56 & 28 & 14 & 7 & -7 \\ \text { Woight } x & 3.2 & 37.5 & 39.5 & 15.5 & 4.3 \\ \text { Woight } \times \text { Passing } & 96.8 & 59.3 & 19.8 & 4.3 & -\end{array}$


TABLE 10.2. Circuit Variations and Pressure-Drop Effects on Magnetite Recovery

\begin{tabular}{|c|c|c|c|c|c|c|c|}
\hline \multirow[b]{2}{*}{ Circuit } & \multirow[b]{2}{*}{ Pressure psi } & \multicolumn{2}{|c|}{8} & \multicolumn{2}{|c|}{15} & \multicolumn{2}{|c|}{25} \\
\hline & & UF & OF & UF & $O F$ & UF & OF \\
\hline $\begin{array}{l}1 \\
\text { No Magnet }\end{array}$ & $\begin{array}{l}\text { wt (g)/5sec } \\
\text { weight } x\end{array}$ & $\begin{array}{l}16.0 \\
85\end{array}$ & 15 & $\begin{array}{l}27.8 \\
88\end{array}$ & $\begin{array}{c}3.9 \\
12\end{array}$ & $\begin{array}{l}38.3 \\
91\end{array}$ & $\begin{array}{l}3.8 \\
9\end{array}$ \\
\hline 2 & $\begin{array}{l}\text { Wt }(g) / 5 \text { sec } \\
\text { weight } x\end{array}$ & $\begin{array}{l}21.3 \\
98\end{array}$ & 2 & $\begin{array}{l}35.3 \\
97\end{array}$ & $\begin{array}{l}1.2 \\
3\end{array}$ & $\begin{array}{l}43.5 \\
97\end{array}$ & ${ }_{3}^{1.2}$ \\
\hline $\begin{array}{l}3 \\
\text { Two Magnets } \\
(N-N)\end{array}$ & $\begin{array}{l}\text { W }(g) / 5 \text { sec } \\
\text { Weight } x\end{array}$ & $\begin{array}{l}16.7 \\
82\end{array}$ & 18 & $\begin{array}{l}35.5 \\
98\end{array}$ & 3 & $\begin{array}{l}42.2 \\
97\end{array}$ & $\begin{array}{l}1.5 \\
4\end{array}$ \\
\hline $\begin{array}{l}4 \text { Two Magnets } \\
\text { (N-S) }\end{array}$ & $\begin{array}{l}\text { W }(g) / 5 \text { sec } \\
\text { Weight } x\end{array}$ & $\begin{array}{l}19.7 \\
94\end{array}$ & $\begin{array}{l}1.3 \\
8\end{array}$ & $\begin{array}{l}29.1 \\
93\end{array}$ & $\begin{array}{l}2.2 \\
7\end{array}$ & $\begin{array}{l}40.6 \\
93\end{array}$ & $\begin{array}{l}3.1 \\
7\end{array}$ \\
\hline
\end{tabular}

expected, when the pressure drop increases in this case, the recovery to underflow increases from $85 x$ to $91 \%$ at $25 \mathrm{psi}$. In all other cases the recover appears to be independent of pressure and magnet configuration, with recovery to underflow being about $97 \%$. The only ajor exception is where two magnets are used with opposite poles positioned adjacent to one another. In this case the recovery figures are reduced to about $93 x$.

At 6 psi, a single magnet can increase the recovery of magnetite fron $85 x$ to $98 x$. The size distribution data for tests 1 and 2 are given in Table 10.3. The size data illustrate that because the magnet has recovered nore fine material, the underflow size distribution has become finer, while the overflow size distribution has coarsened. To test the effect of cyclone geonetry on recovery, the $9.8 \mathrm{~cm}$ spigot nozzle was removed and tests were conducted with an effective spigot diameter of $1.6 \mathrm{~cm}$. The test results indicated that the larger spigot had little effect on the ordinary cyclone ( $84 \%$ solids recovery), but the magnetic cyclone perforaance increased to $99 x$ solids' recovery.

Using the larger spigot, tests were then undertaken with increased pulp density. Table 10.4 illustrates that the magnetic cyelone performance increases with increasing aagnetite foed wight, and that at higher pulp

TABLE 10.3. Size Distribution Data for Tests 1 and 2 at 6 psi

\begin{tabular}{|c|c|c|c|c|}
\hline \multirow{2}{*}{$\begin{array}{c}\text { Size } \\
\text { (nicron) }\end{array}$} & \multicolumn{2}{|c|}{ Test 1} & \multicolumn{2}{|c|}{ Test 2} \\
\hline & $U_{F}$ & UfF & UF & OF \\
\hline 56 & 5.2 & 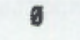 & 4.9 & $\theta$ \\
\hline 28 & 37.4 & 6 & 28.6 & 23.8 \\
\hline 14 & 39.0 & 6.9 & 44.2 & 14.3 \\
\hline 7 & 13.7 & 49.3 & 18.4 & 33.3 \\
\hline-7 & 4.7 & 43.8 & 5.9 & 28.6 \\
\hline & 100.6 & 100.0 & 160.0 & 160.6 \\
\hline
\end{tabular}

TABLE 10.4. Effect of Increased Feed Solids' Content on Solids' Recovery in the One Wagnet Cyclone Conf iguration

\begin{tabular}{|c|c|c|c|c|}
\hline $\begin{array}{l}\text { Feed } \\
\text { Sol ids (q) }\end{array}$ & $U F t(g)$ & UF $w t x$ & of $w t(g)$ & OF wtX \\
\hline 560 & 15.1 & 99 & 6.2 & 1 \\
\hline 1500 & 68.2 & 99 & 0.6 & 1 \\
\hline 4000 & 210.3 & 166 & 9.6 & 0 \\
\hline 5590 & 217.4 & 100 & 0.7 & 0 \\
\hline
\end{tabular}


densities the solids' recovery figures approach 106x. An approxinate calculation of the actual pulp densities used in these tests gives values of 10 to $10 \mathrm{X}$ solids by weight.

Table 10.4 shows that the magnetic cyclone is very effective at recovering magnetite in a range of feed densities, which is representative of the four plant process strean sanples discussed later. However, the process stream sanples gave quite different results, as discussed in the following section.

\section{Test Results from Coal Plant Process Streans}

Two Missouri coal nining operations, located in the Moberly district, were visited, and sanples of two pulp streams at each wine were taken. At the first aine, the samples taken represented the tails (B) from the drun nagnetic separator and the overflow product $(A)$ from a cyclone, which concentrates the dilute magnetite pulps before it reaches the drun magnetic separator. Both samples represent streans, shown in Figure 10.6, in which magnetite could be lost. The first potential magnetite loss would result from magnetic separator inefficiency, and the second from magnetite fineness, which would keep the agnetite froe being directed to the magnetic separators.

At the second nine, one sample was again taken from the drum magnetic separator tailing (M), but the other sauple came from a final plant discharge slurry (S), containing the gangue or waste products. Table 10.5 provides physical data relating to the four samples. The data include agnetite content, solids concentration, and size paraneters.

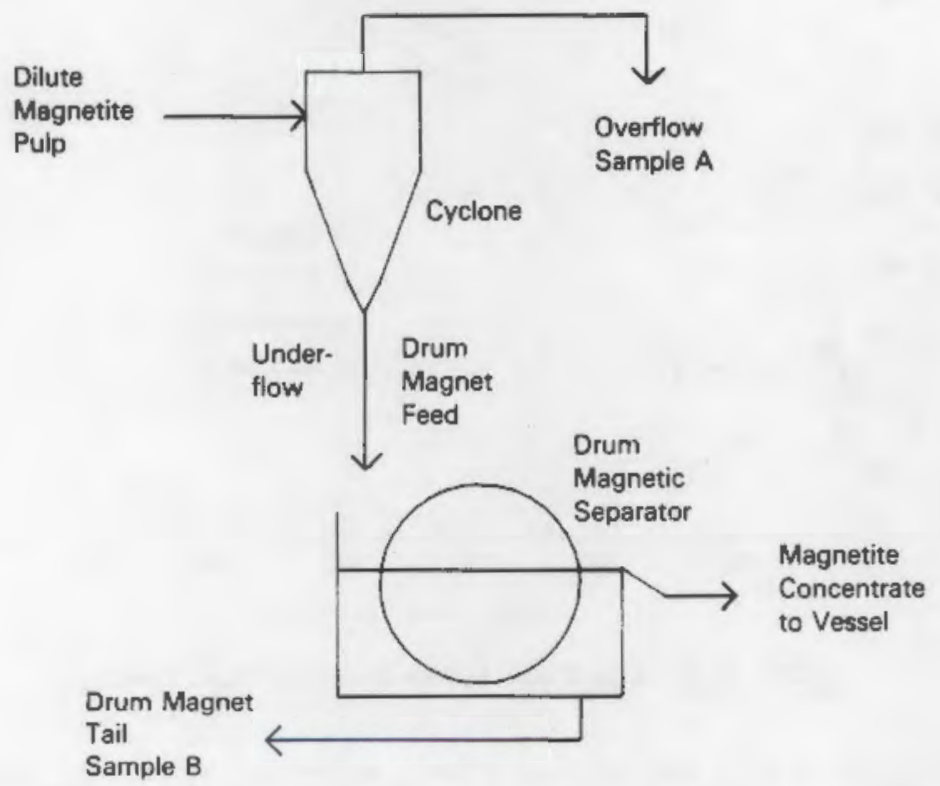

FIGURE 10.6. Sample Locations in Magnetite Recovery Circuit

TAQLE 16.5. Physical Data for the Four Mobberley Samples

\begin{tabular}{|c|c|c|c|c|}
\hline Solids & Sanple B & Sample A & Sample & Sample S \\
\hline Content $(g / I)$ & 111.5 & 46.2 & 182.7 & 125.8 \\
\hline wt $x$ & 16 & 4 & 16 & 11 \\
\hline X Uagnetito & 4 & 96 & 100 & 0 \\
\hline$x>150$ aicrons & 52 & 27 & 13 & 34 \\
\hline$x<14$ microns & 16 & 39 & 39 & 20 \\
\hline
\end{tabular}


Table 10.5 shows that sanples $A$ and $M$ contain high proportions of magnetite, wile sanplo $S$ is surprisingly magnetite-free. The recovery of magnetite at the first ine is effective in the drum magnetic separators, but losses do occur in the cyclone overflow prior to magnetic separation. At the second aine, the magnetic separators are less effective and a tail containing virtually pure magnetite is produced.

The size distribution data are presented in Figure 10.7, which shows that the curves are not snooth, indicating that the samples are probably the combination of different materials. Because dense media magnetite is essentially less than 75 microns in size, the coarser material present in the samples most likely represents gangue waterials from the raw coal. Samples $A$ and $M$ display a considerable proportion of particles less than 14 nicrons, representing a potential magnetite loss.

Sanple A-Cyclone Overflow Product. The results of the tests using $560 \mathrm{~g}$ of solid froe Sample A (96x magnetics) at a pressure of 6 psi are given in Table 16.6. The spigot diameter for all the four plant sanples was maintained at $0.8 \mathrm{~cm}$. These results show that the recovery of agnetite is very difficult even with the magnet configuration, which recovered only $33 \%$ of solids. This results fron the extreme fineness of Sample $A$, which contains $39 \%$ of the particles finer than 14 sicrons.

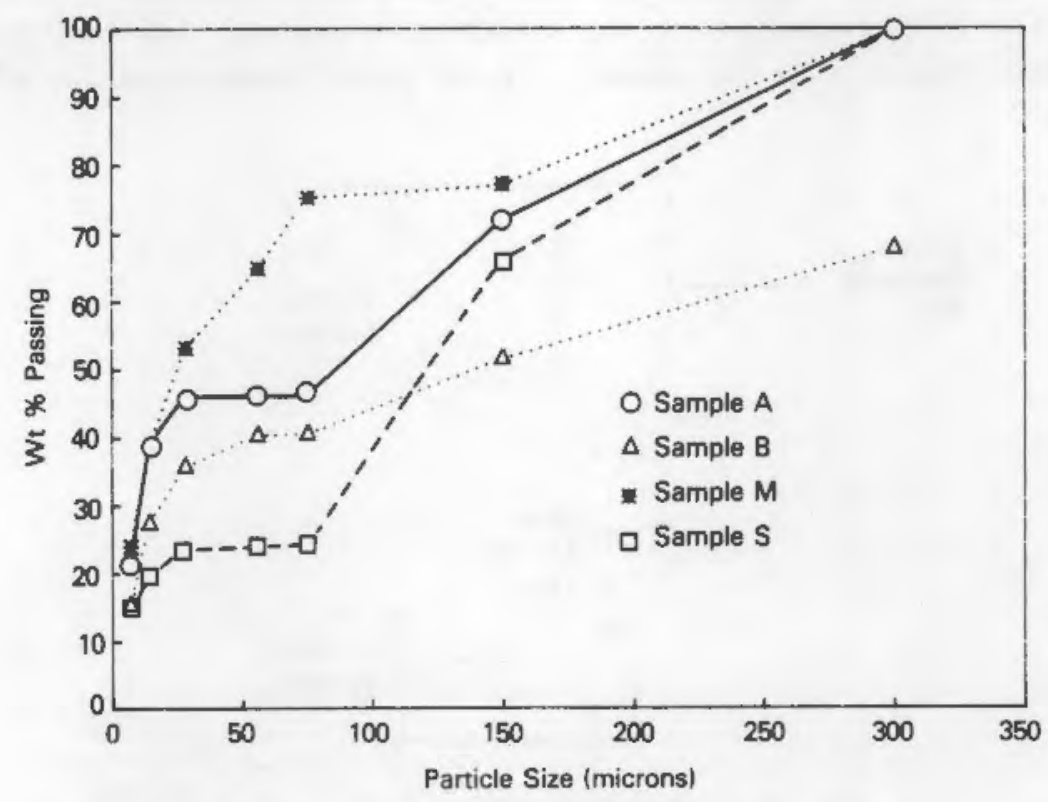

FIGURE 10.7. Size Distribution Data for Plant Sanples

TABLE 10.6. Cireuit Conf iguration Effects on Solids' Recovery for Sample A

Wt(g) Wtx Recovery Solids

$\begin{array}{llrll}5 & & & & \\ \text { No Magnet } & \text { UF } & 5.6 & 38 & 4.1 \\ & \text { OF } & 13.3 & 76 & 6.5 \\ 6 & & & & \\ \text { One Magnet } & \text { UF } & 5.6 & 33 & 4.2 \\ & \text { OF } & 11.2 & 67 & 0.5 \\ 7 & & & & \\ \text { Two Magnets } & \text { UF } & 5.4 & 32 & 4.1 \\ & \text { OF } & 11.3 & 68 & 0.5\end{array}$


Sample B - Nagnetic Drun Separator Tail. The results froe the circuit testo are given in Table 10.7 for the three configurations at 6 psi pressure drop for Samplo $B$ (4x agnetics). As expected fron the analysis of the feed aterizl, the eagnetic recoveries are only slightly higher by using the eagnetic cyclone because only $4 \pi$ of the feed material is magnetite. Obviously, in this case it would be desirable to separate the wagnetite fron the gangue uaterial by imposing conditions such that under noreal cyclone conditions, all the material reports to the overflow. Then the application of a eagnetic field would cause only the magnetito to report to the underf lor. This could be achieved by using a larger dianeter cyclone.

Sample S - Discharge Slurry. Because Samplo S has no magnetic materiat, the magnetic cyclone test data are not relevant and are not reported here.

Sangle W - Drun Magnetic Separator Tail. The results for the eagnetic eyclone tests on Sample M (100x nagnetics) are shom in Table 16.8. The table shows that the solids' recovery from Saeplo $y$, which contains essentially eagnetite only, can be increased from $58 x$ to $82 x$ by applying a magnetic field across the cyclone. The size distributions of the cyclone products are shom in Figure 10.8, and it is apparent that the agnetic cyclone has recovered finer aterial to the underflow. Therefore, the overflow product has coarsened and the underflou product has becone finer. Again, the fineness of the waterial (395 less than 14 microns) has wade the recovery difficult.

\subsubsection{Application 2 - Steol Plant Sludge Dewatering}

The U.S. steel industry has encounterad a sovere problen with using and disposing of dry dusts or sludges resulting fron stooluaking operations [Laboratory for Environnental Research (LER) 1988]. The various stoolaaking processea generate dusts as by-products, and these dusts are renoved fron furnace gases generally in wot scrubbers, wich resulto in the production of sludges. About 10 to 20 kilograns of dust are generated per ton of liquid steel produced [U.S. Bureau of Wines (USB) 1979]; this is equivalent to over 2 aillion tons of dust for a U.S. steel production rate of 130 million tons.

TAQEE 10.7. Cireuit Configuration Effects on Solids' Recovery for Sample $B$

\begin{tabular}{|c|c|c|c|c|}
\hline & & It (g) & Wti Recovery & Wty solids \\
\hline No Hagnet & $\begin{array}{l}\text { UF } \\
\text { OF }\end{array}$ & $\begin{array}{r}12.4 \\
5.2\end{array}$ & $\begin{array}{l}70 \\
30\end{array}$ & $\begin{array}{l}7.2 \\
6.2\end{array}$ \\
\hline $\begin{array}{l}9 \\
\text { Dne Hagnet }\end{array}$ & $\begin{array}{l}\text { UF } \\
\text { OF }\end{array}$ & $\begin{array}{r}13.5 \\
5.6\end{array}$ & $\begin{array}{l}71 \\
27\end{array}$ & $\begin{array}{l}8.1 \\
0.2\end{array}$ \\
\hline Two Kagneto & $\underset{\text { UF }}{\text { UF }}$ & $\begin{array}{r}13.4 \\
5.2\end{array}$ & $\begin{array}{l}72 \\
28\end{array}$ & $\begin{array}{l}7.7 \\
0.2\end{array}$ \\
\hline
\end{tabular}

TABLE 10.8. Circuit Conf iguration Effect on Solids' Recovery for Sample I

\begin{tabular}{|c|c|c|c|c|}
\hline & & $\underline{w}(\mathrm{q})$ & ItX Recovery & Solids \\
\hline $\begin{array}{l}11 \\
\text { Mo Wagnet }\end{array}$ & $\begin{array}{l}\text { UF } \\
\text { OF }\end{array}$ & $\begin{array}{r}11.2 \\
8.7\end{array}$ & $\begin{array}{l}58 \\
44\end{array}$ & $\begin{array}{l}8.7 \\
0.4\end{array}$ \\
\hline $\begin{array}{l}12 \\
\text { One Magnet }\end{array}$ & $\begin{array}{l}\text { UF } \\
\text { OF }\end{array}$ & $\begin{array}{r}13.2 \\
8.0\end{array}$ & $\begin{array}{l}62 \\
38\end{array}$ & $\begin{array}{l}9.9 \\
9.3\end{array}$ \\
\hline $\begin{array}{l}13 \\
\text { Two Uagnets }\end{array}$ & $\underset{\text { OF }}{\text { UF }}$ & $\begin{array}{r}12.7 \\
7.8\end{array}$ & $\begin{array}{l}82 \\
38\end{array}$ & $\begin{array}{l}9.7 \\
6.3\end{array}$ \\
\hline
\end{tabular}




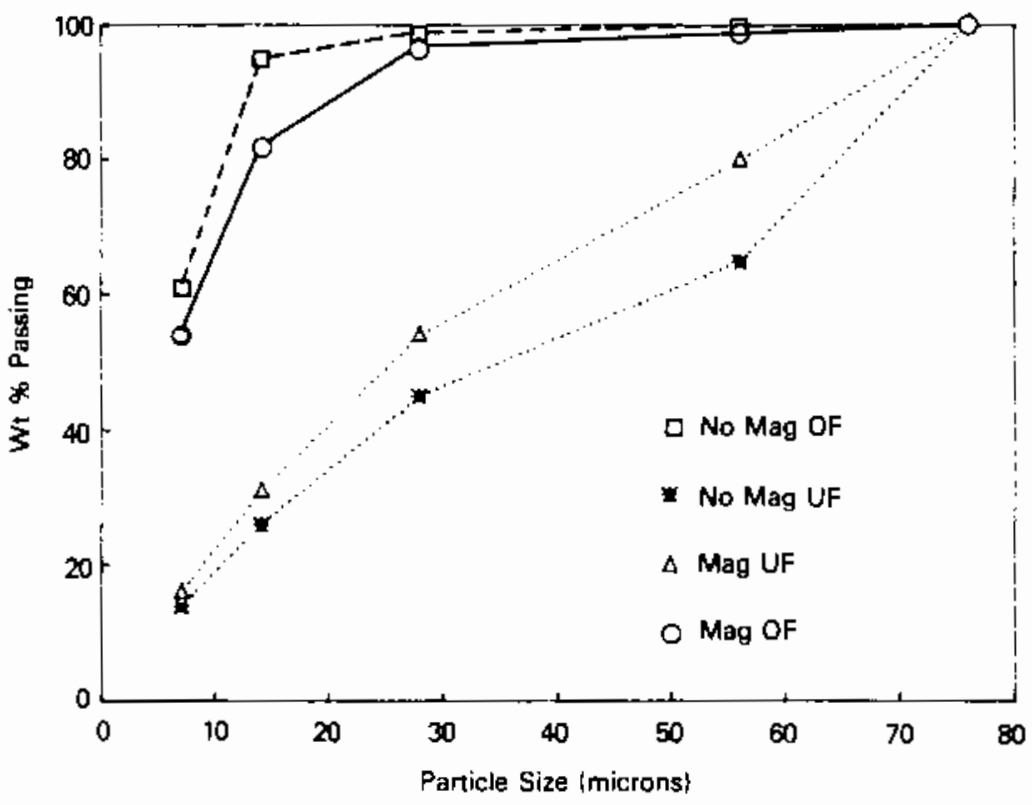

FICURE 10.B. Size Diatribution Data for Cyclone Products

These sludges contzin appreciable quantities of iron (25x to 705) and therefore represent an iron resource. Currently, this aterial is disposed of in landfills. As the presence of zinc in these sludges increases, the eaterial becomes increasingly toxic and ill dranatically increase future fandfill costs. These sludges can bo comercially recycled, but the recycling is linited to materials having a high zinc content becauso the recovered zinc values ake the treateent process ocononical (Price 1988; Fosnacht 1985; Little 1993).

One mjor probles associated with treating all sludgos is the rewoval of water to lower transport costs and to prepare the eaterial for processing or efficient landfill disposal. A typical sludge contains fron 5x to $36 x$ solids by wight; for offective handling and treatenent this wust be raised to solids contents in excess of $76 x$. Steelaaking dusts typically are vory fine (LER 1996), with median particles frequently ranging froe about 8 to 10 microns. These sludges represent suitable foeds to suall dianeter cyclones, particularly if agnetic forces can be used to augment the nornal classification forces.

Sone sludges contain large proportions (up to 7ax) of iron as agnetite, and it is the devatering of these anterials that represents a possible application for the magnetic cyclone. Because olectric arc furnace (EAF) dusts are approximately $99 x$ magnetic, they would be a good food malorial for magnetic eyclone tests. Millscale also has a high iron content and is a suitable eaterial for the eagnetic cyclone. Table if.9 suatarizes tho characteristics of these tro potential feed materials for the magnetic cyclone.

At this tise, no test work has been undertaken because samples fron the sted industry vere unavailabie. Requests have been ande to ateol plants in the Northrest Indiana area, but to date no samples have been received. The test work ill be undertaken thon appropriate sanples can be obtzined.

TABLE 19.9. Characteristics of EAF and Millscalo Vaterial (LER 1988)

\begin{tabular}{|c|c|c|c|c|}
\hline Vaterial & TFo & $x \geq n$ & $\begin{array}{l}\text { 100x Passing } \\
\text { (aicrons) }\end{array}$ & Tons/Year \\
\hline EAF & $39-44$ & $3-6$ & 100 & 36,800 \\
\hline Viltscale & $72-76$ & $3-6$ & 500 & 728,600 \\
\hline
\end{tabular}




\subsection{FUTRE DEYE OPNENT}

The first step needed to further develop this concept is to complete the initial assessnent process. Then, the nost promising application process for the nagnetic cyclone can be identified. Other possible applications ma arise and merit further investigations as a result of the project report and the oral prosentation in Washington. Dbviousty, the prinary requirenent in any dovelopnent plan is to interest a potential user, and then to construct a tast rig on site and prove the concept on a pilot plant scalo in a real industrial situation. The key to any utilization must be a process to perait the unique properties of the magnetic cyclone to be exploited.

\subsection{REERENCES}

Electric Powar Research Institute (EPRI). 1985. Warket Survey of Fly-Ash-Derived Magnetite. CS 3615, Palo Alto, California.

Fosnacht, D. R. 1985. 'Characterization and Utilization of Iron-Bearing Steol Plant Tasto Materials.' Maerican Institute of Nining and Lotallurgical Engineors, Annual Heoting, New York.

Fricker, A. G. 1985. Magnetic Hydrocyclone.' TransI Section C, p. 94.

Hiow, H. 1891. 'Beneficiation of Minerals with Magnetic Hydrocyclones.' H. Min. Tech Theais, University of Otago, New Zealand.

Latoratory for Environeental Rosearch (LER). 1986. 'Feasibility of Recyciing Zine Bearing Dusts and Sludges." Indiana University Northwest, Gary, Indiana.

Leonard, J. ., and D. R. Hitchell. 1988. Coal Preparation. Maerican Institute of Hining and Hetallurgica! Engineers, Nev York.

Little, A. D. 1083. Steel Waking Residue Recycling Processes. Propared for the U.S. Department of Energy, Washington, D.C.

Price, L. E. 1988. 'Tensions Lount in the ENF Dust Bovl.' Motal Producing. 33(2).

U.S. Bureau of Uines (USB). Hay 1979. 'Zine Mineral Commodities.' Iashington, D.C.

Watson, J. L. 1978. 'Magnetic Assessent of Taipipi Ironsands.' Non Zealand Journal of Sciences. 22:87-98.

Hatson, J. L., and Aaoko-Gyanpah. 1983. 'Cycloning in Magnetic Fields.' Fall Weoting of the Aaerican Institute of Wining and Letallurgical Engineers and the Society of Mining Engineers, Salt Lake City.

Watson, J. L., and A. F. Low. 1982. The Roto of Titanomagnetite Concentrates in Gravity Separation of New Zealand Iron Sands." Process Vineralogy II. Ed. R. Hagni, Society of Uining Engineers, Marrendalo, Pennsylvania. 
. 
APPEIOIX

ADDRESS LIST OF SUBCONTRACTORS 


\section{ADORESS LIST OF SUBCONTRACTORS}

\section{R. J. Adler}

(216) 388-4121

Departaont of Chenical Engineering

Case Western Reserve University

University Circle

Cloveland, thio 44166

v. B. Baratuc $i$

(216) $368-4425$

Departeent of Chenical Engineering

Case Festern Reservo University

University Circlo

Clevoland, Ohio 44168

L. J. Cornell

(216) 382-5829

Department of Chesical Engineering

Case Vestarn Reserve University

University Circlo

Cleveland, ohio 44168

K. N. Han

(605) 394-2341

Departnent of wotallurgical Engineering

South Dakota School of Kines and Technology

Rapid City, South Dakota 57791

Y. J. Hruby

(617) 527-2068

$\mathrm{J}$. Busek Co., Inc.

Herton, Massachusatts 02168

J. H. Johnson, Jr.

(292) 838-6570

Howard University School of Engineering

Washington, D.C. 20659
S. K. Kavatra

(968) 487-2664

Vichigan Technological University

Departwent of Hotallurgical Engineering

Houghton, Nichigan 49931

H. R. Ladisch

(317) 494-7822

Laboratory of Renewable Ressources Engineering

Purdue University

Tost Lafayotte, Indiana 47997

D. L. Micheisen

(7ø3) $981-5157$

Yirginia Tech

Blacksburg, Virginia 24661

Charles A. Potty

(517) 363-5486

Departsent of Chencial Engineering

Vichigan State University

East Lansing, Michigan $\mathbf{4 8 8 2 4}$

Felix Sobba

(763) $961-8753$

Department of Chenical Engineering

Virginio Polytechnic Institute

and State University

Blacksburg, Yirginia 24861

J. L. Vatson

(314) 341-4711

Departaent of Wotallurgical Engineering

University of Missouri-Rolla

Rolla, Missouri 65461-0240 


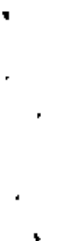

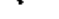

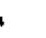


No. of

Copies

OFFSITE

50 T. M. Levinson

U.S. Departenent of Enargy Forrestal Building 1080 Independence Avenue SI Tashington, $O C 26525$

10 V. U. Sonnet U.S. Departwent of Energy Forrestal Building 1600 Independence Avenue, St Tashington, $D C 20585$

10 OQE/Office of Scientific and Technical Infornation
No. of

Copies

ONSITE

DOE Richland Operations office

J. J. Sutoy

144 Pacific Northeost Laboratory
R. C. Adans
C. L. Bruneau
B. A. Garrett
J. J. Hauth
V. E. Lee
R. U. Suith
S. A. Suith
R. L. Watts (130)
Tochnical Roport Files (5)
Publishing Coordination (2) 
